Fordham University

\title{
DigitalResearch@Fordham
}

\section{Scholars, Friends, Plagiarists: The Musician as Author in the Seventeenth Century}

\author{
Eric Bianchi \\ Fordham University, ebianchi1@fordham.edu
}

\section{Recommended Citation}

Bianchi, E. (2017). Scholars, friends, plagiarists: The musician as author in the seventeenth centruy. Journal of the American Musicological Society, 70(1), 61-128.

Follow this and additional works at: https://fordham.bepress.com/art_hist_facultypubs

Part of the History of Art, Architecture, and Archaeology Commons, and the Music Commons

This Article is brought to you for free and open access by the Art History and Music at DigitalResearch@Fordham. It has been accepted for inclusion in Art History and Music Faculty Publications by an authorized administrator of DigitalResearch@Fordham. For more information, please contact considine@fordham.edu, bkilee@fordham.edu. 


\title{
Scholars, Friends, Plagiarists: The Musician as Author in the Seventeenth Century
}

\author{
ERIC BIANCHI
}

\begin{abstract}
ny weather can prompt a good humanist dialog. Mild skies lured Felice and Giuseppe, interlocutors in Angelo Berardi's Ragionamenti 1 musicali (1681), into the countryside for a stroll. ${ }^{1}$ Sweltering heat forced Flavio and Martio, interlocutors in Berardi's Arcani musicali (1690), to seek respite in polite conversation:
\end{abstract}

FLAviO. Today, when Sirius burns more fiercely than usual in the heavens, I can feel no refreshment more welcome than to enjoy the honor of your delightful and gracious conversation.

MARTIO. In this season, when the land, parched and lashed by the sun's scorching rays, has not even enough water in her streams to refresh her lips, I come to enjoy the sweet murmur of the perennial font of virtue, which restores my soul and gives spirit and life to the heart. ${ }^{2}$

I gratefully acknowledge the many institutions and individuals whose generosity has made this study possible. Research was undertaken with support from the American Academy in Rome, the Scuola Normale Superiore di Pisa, my home institution Fordham University, and the Harold Powers Travel Fund of the American Musicological Society. In fall 2015, while in residence at the Italian Academy for Advanced Studies at Columbia University, I presented my research both at Columbia and at the annual meeting of the American Musicological Society in Louisville, KY. Several librarians provided crucial access to materials at their institutions: Mons. Paolo Bonato and Emilia Mangiarotti of the Archivio Capitolare in Vigevano, the staff of the Biblioteca Angelica in Rome, Francesco Cignoni of the Biblioteca Statale di Cremona, Domenico Carboni and Tiziana Morsanuto of the Biblioteca Governativa del Conservatorio Santa Cecilia in Rome, and Riccardo Artico of the Biblioteca Casanatense in Rome. I benefitted from all those who freely shared their work and expertise with me and asked penetrating questions: several anonymous reviewers for this Journal, Renata Ago, Tim Allen, Gregory Barnett, Riccardo and Roberto Bellazzi, Susan Boynton, Tim Carter, Arianna Cecconi, Leon Chisholm, Jennifer Coates, Rebecca Cypess, David Freedberg and the participants of an Italian Academy seminar, Roger Freitas, Matthew Gelbart, Giuseppe Gerbino, John Holmes, Robert Holzer, David Humphrey, Gundula Kreuzer, Jeffrey Kurtzman, Stefano Lorenzetti, Loren Ludwig, Margaret Murata, Carmel Raz, André Redwood, Christoph Riedo, Kurt Rohde, Ellen Rosand, Nina Rowe, and Huub van der Linden. Extraordinary thanks are due to Christine Jeanneret, who has by now endured much more than her fair share of Don Angelo Berardi.

1. Berardi, Ragionamenti musicali, 16.

2. Berardi, Arcani musicali, 7: "Flav. Hoggi, che più del solito brugia si fieramente il cirio nel Polo, refrigerio più grato non potevo sentire, che godere l'honore della sua amabile, e grata conversatione. Mart. In questo tempo, che la Terra inaridita, e flagellata dà raggi cocenti, non hà

Journal of the American Musicological Society, Vol. 70, Number 1, pp. 61-128 ISSN 0003-0139, electronic ISSN 1547-3848. @ 2017 by the American Musicological Society. All rights reserved. Please direct all requests for permission to photocopy or reproduce article content through the University of California Press's Reprints and Permissions web page, http://www.ucpress.edu/journals.php?p=reprints. DOI: https://doi.org/10.1525/jams.2017.70.1.61. 
Fully a fifth of the dialog passes before Flavio and Martio broach their first musical concern: can one sing a composition without clefs? "Arcani musicali" indeed. Flavio and Martio are in no hurry: time and words are to be spent liberally in their charmed world.

Modern scholars have found that poetic otium led to otiose prose. Although they turn to composer-theorist Berardi (1636-94) for information on musical style and technique, they only reluctantly engage what they consider derivative and irrelevant: digressions on friendship, virtue, compositional curiosities, and musical science. That these could be characterized as digressions - distractions from the real work of musicology - speaks to the remoteness of Berardi's world. By the eighteenth century Charles Burney was already complaining that "if the whole [of Berardi's work] had been compressed, methodised, and digested into a single treatise ... a more useful and practical didactic work might have been produced." And for FrançoisJoseph Fétis, Berardi's writing exemplified the problematic of the seventeenth century, an epoch in which "the goal of musical study was misunderstood" to be a search for "puerile subtleties."3

Luckily for Berardi, neither Burney nor Fétis knew the whole truth. As I demonstrate through discussion of several archival discoveries, Berardi was a career plagiarist. He took most of his words from his mentor, the composer and polemicist Marco Scacchi (d. 1662). I will not condemn him for it. Quite the contrary: I will argue that the very techniques of textual facture prove revelatory, complicating and enriching for us even the most derivative of musical writings. Through Berardi, his half dozen treatises, and the literary persona he projected through them, we explore more broadly the writings and personae of late seventeenth-century musicians. Rather than looking through these writings as windows onto musical objects (works, styles), we look at them as reflections of musicians' crafted personae. The writers I discuss had ties to an area extending from Rome to Bologna, the political and musical centers of the Papal States and the poles of Berardi's career. Yet the issues range beyond a single composer and his immediate surroundings: a similar article could find its heart elsewhere (the Habsburg Empire, for instance).

Berardi was long ago relegated to the dubious category of "source." He is no one's idea of a great composer, pioneering theorist, or compelling writer. But as a representative figure he shines. Historian Eric Cochrane memorably criticized the widespread tendency to dismiss that which "seems in

tant'acqua ne suoi ruscelli per rinfrescarsi le labbra, vengo à godere il dolce mormorio di quel fonte perenne di Virtù, che mi ricrea l'animo, e da spirito, e vita al Cuore." All translations are mine. In transcribing passages from both print and manuscript souces I have used italics to mark the expansion of abbreviations and square brackets to fill out lacunae and rectify errors. I have silently changed " $u$ " to " $v$ " and " $\mathrm{j}$ " to "i" in accordance with modern orthographical convention.

3. Burney, General History of Music, 3:542; Fétis, Biographie universelle des musiciens, 2:141: "à l'époque où Berardi publia ses Documenti armonici, il semble, qu'on avait méconnu le but des études musicales . . . à celle de subtilités puériles.” 
retrospect to have been miscalculated, ineffective, retrogressive, or derivative, [as] not worth studying - as if no one counted in this world except the very few geniuses who happen to have been appreciated by their posterity." ${ }^{4}$ No doubt about it, the writings of Berardi and his peers are nothing if not derivative. Moreover, they brim with ideas that were then old-fashioned and are now unfashionable; with formulations that are confused and confusing; with flabby, flapdoodle prose. And that is precisely why they offer a singular view into the heart-the great middledom, that is - of seventeenth-century musical culture: the somewhat anonymous workforce that kept a vast network of musical chapels and courts running smoothly. These writings speak to the condition of musicians, and speak most clearly at their most irrelevant and derivative. Musicians faced epistemological and social challenges: the theory of music outranked its practice and theorists outranked practitioners. As Andrew Dell'Antonio demonstrates, the "discourse[s] about music" born in seventeenth-century Rome were exclusionary discourses: by excluding and denigrating the language of musicians they excluded and denigrated musicians themselves. ${ }^{5}$ Yet these challenges offered possibilities to Berardi and his contemporaries. I argue here that musicians, in their turn, adopted and manipulated those very discourses in order to rise above their station: they presented themselves as writers and scholars, and avoided the "merely" musical. They emulated practitioners from a variety of professions who, in status-obsessed Italy, constructed and projected intellectual personae through theoretical writings. Such writings, Renata Ago observes, offered a means to "[pretend] that [the] special quality of their activities placed them in a separate rank: if they did not belong to the titled nobility, they certainly were not members of the laboring ranks of the society."

From his earliest publications Berardi crafted a corpus and a persona that spoke through others' words; he inserted himself into his texts as an identifiable personage. The "Berardi" that emerges from these writings is a pastiche-and a coherent one. Of course, I am teasing Berardi somewhat by calling him a plagiarist; no single term quite captures this facet of his literary technique. Plagiarism, parody, pastiche, borrowing, theft, imitatio, inventio: some form of each word existed in the seventeenth century. They referred to a spectrum of centuries-old practices that were endemic in pedagogy, literature, scholarship, and musical composition. They met (and meet) with both praise and blame. In the realm of musical composition Bach seeded cantatas with well-known chorales; Handel's wide borrowing from the music of his contemporaries provoked the occasional wry comment; Giovanni Bononcini simply presented Antonio Lotti's work as his own—and was vilified for it. As for borrowing in writings about music, however, Thomas Christensen

4. Cochrane, Florence in the Forgotten Centuries, xiv.

5. Dell'Antonio, Listening as Spiritual Practice, 1-10.

6. Ago, "Possessions and Reputation," 2. 
concludes that "we just do not know, as little of this ... literature has ever been subjected to systematic scrutiny." B Berardi's writings offer a glimpse of the persistence, extent, and complexity of these practices, which not only embraced something we might recognize as plagiarism but also served purposes ranging from didactics to witty allusion and even homage.

For our purposes, these practices (however we choose to refer to them) ultimately serve as a point of departure rather than as a goal. They will turn attention away from the musical information in a given text and refocus it upon the self-conscious construction of persona. Thus the particularities of Berardi's case gradually open onto larger questions about musicians' authorship and about the work their literary texts might perform in a world beyond music. To better hear their authorial voices amid seventeenth-century musical conversations, we sample three strains of discourse about music: musicians' professional concerns, the effusions of polite academies, and the erudition of polymaths. These strains are characterized as much by context (class, education, profession) as by musical content; although they intertwine and overlap, they are nonetheless distinct. In Berardi's case, Scacchi's writings provided grist for his treatises but were too polemical and practical to offer entrée into higher society. Scacchi treated matters of mode and counterpoint that fueled important disputes within the professional sphere but carried far less cachet beyond it. Berardi repackaged his Scacchiana attractively by appropriating and emulating his social betters. He sought to produce more than gracious texts; he aimed to create a persona that would be welcome in gracious circles. He chose gentlemanly friendship as his guiding conceit and enshrined his "ideal" friendship with Scacchi as its exemplar. The musical discourses of academies and erudites, in social tone and metaphysical outlook, often perpetuated Boethian prejudices against practicing musicians. For obvious reasons, many musicians (such as Scacchi) were little interested in (or even hostile to) these discourses. Yet the very factors that made them unappealing to some musicians made them quite attractive to others. There is a high degree of congruence in literary tone, topic, and technique between Berardi's writings and those of contemporary musicians, such as Agostino Steffani, Antonio Abbatini, and Giovanni Andrea Angelini Bontempi.

The circumstance of borrowing, the conventionality of borrowed material, and the social advantages presented by borrowing it: taken together, these obscure any easy relationship between persona and anima. This condition recalls the nature of human identity in Gilles Deleuze's postmodern Baroque,

7. Christensen, "Fragile Texts, Hidden Theory," 199; a notable exception is found in Herissone, Music Theory, 14-25. I would add that these practices by no means ended with the seventeenth century. I have discovered that, although Charles Burney made liberal use of others' work, he nonetheless charged Johann Nikolaus Forkel with "unfair use . . . of my property" and John Hawkins with "absolute plagiarism": Burney, "Materials," 60, and "Remarks," 6. Carmel Raz has discovered extensive borrowing in the nineteenth-century musical writings of Peter Joseph Schneider: Raz, "Reverberating Nerves," 15-19, 30-32. 
where hyperarticulated exteriors mask opaque and vacant interiors. ${ }^{8}$ I profess agnosticism as to when (or whether) statement coincided with the more evasive category of "belief." Questions about musicians' mental worlds seem destined for irreducible uncertainty and fruitful speculation. The final sections of this article entertain both, through the metaphysical and methodological issues raised in these very conventional musical writings. Some have received scholarly attention, especially where early modern musical and scientific cultures overlapped, as in the case of the deep interest in natural magic that continued across the seventeenth century. Gary Tomlinson, in Music in Renaissance Magic (1993), attempted an archaeology of the musico-magical as a means of broadening musicological discourse beyond “composers' expressive aims." Likewise, Penelope Gouk, in Music, Science and Natural Magic in Seventeenth-Century England (1999), explored the nexus of "musical thought" and magic in the Scientific Revolution so as to offer a view of musical culture beyond "canonical accounts of great composers and their works." Their research resists easy integration into musicology. The intractable strains of metaphysical and scientific thought they treat, and subjects whom they investigate (poetic philosophers such as Marsilio Ficino, natural philosophers such as Isaac Newton), would seem to lie far from the "musically significant." It is one thing to accept Tomlinson's conclusions for Ficino, quite another to reconcile them with long-standing disciplinary priorities surrounding musical works and repertories - as both Tomlinson and Gouk recognize.

This article attempts to bring such intellectual concerns into closer relation with those of professional musicians. Clear continuities link the writings of polymaths to those of practitioners. Nevertheless, I also emphasize a crucial difference between them, itself a significant motivation for literary borrowing. Intellectuals such as Juan Caramuel y Lobkowitz and Athanasius Kircher enjoyed a magnificent education. The burning controversies (heliocentrism, atomism) that animate their erudite writings leave little trace in those of Berardi and his peers. Musicians, if they received a formal education, generally received one of a fundamentally different kind. While "good enough" for a garden-variety cleric, it placed them at a disadvantage among aristocrats and courtiers. Thus it would be somewhat misleading to view the various social and professional groups as forming a single intellectual (or even music-theoretical) landscape. The terrain did not unfold in gentle plains; it was pocked with crags whose nooks fostered peculiar microclimates. Two extreme examples will suffice. In his Regole di musica (1657) Franciscan Giovanni d'Avella sketched an improbable music history in which

\footnotetext{
8. Deleuze, The Fold.

9. Tomlinson, Music in Renaissance Magic, 229; Gouk, Music, Science and Natural Magic,
} $3-4$. 
Gregory the Great and Guido of Arezzo were contemporaries. ${ }^{10}$ In the massive Escuela música (1723-24) of another Franciscan, Pablo Nassarre, time stood still: he cited almost nothing published after $1615 !^{11}$ Calling the one "wrong" and the other "conservative" reveals little. Musicians such as d'Avella, Nassarre, and Berardi inhabited a different world from the polymaths Caramuel and Kircher, one that seems scarcely troubled by Galileo and Descartes. Venerable textbooks such as Gregor Reisch's Margarita philosophica (1503) still offered a reliable map. ${ }^{12}$ Currents that Tomlinson locates in the fifteenth and sixteenth centuries continued to flourish, in idiosyncratic ways, through the end of the seventeenth century and beyond. ${ }^{13}$ Because musicology has devoted considerable energy to musical works and to the "innovative" or "progressive," we know little of the mental terrain that most musicians actually inhabited. Understanding "Berardi" - to use a conceit that would have pleased him-requires hearing the resonances between the microcosm of his work and the macrocosm of his universe: both the brighter stars and the lesser luminaries. Although common elements from their musical universe persist, we arrange them around a different center of gravity.

\section{Il maestro e lo scolare: Berardi's Literary Apprenticeship}

By the time of his death at age fifty-eight in 1694 Berardi had served as maestro di cappella at several cathedrals near Rome. He closed his career at the Roman basilica of Santa Maria in Trastevere. He was the dedicatee of three music prints, and published about a dozen collections of his own music as well as six volumes of musical writings (see Table 1). Despite a visible career, we know almost nothing about Berardi beyond what can be gleaned from his publications, such as the important fact of his study with Marco Scacchi. And it is here that Berardi enters the documentary record: he witnessed Scacchi's third will and testament in 1659.

By 1651 Scacchi had retired to Gallese, within roughly thirty miles of Montefiascone and Viterbo, where Berardi lived during the late 1650s and early 1660s. ${ }^{14}$ Scacchi's retirement concluded decades of distinguished service to the Vasa monarchy in Poland. ${ }^{15}$ Around 1633 he had succeeded his

10. D'Avella, Regole di musica, 2-3. Notwithstanding such errors, d'Avella was cited by writers I discuss: see, for example, Berardi, Miscellanea musicale, 171, and Bontempi, Historia musica, 181 .

11. One exception—notable, given Nassarre's blindness—is Kircher's equally massive $M u$ surgia (1650).

12. On Reisch's Margarita philosophica, see page 111 below.

13. Gouk criticizes the sociological and chronological shortcomings of the Foucauldian episteme (the critical tool upon which Tomlinson bases his analysis), although she acknowledges Tomlinson's attempts to address them: Gouk, Music, Science and Natural Magic, 14-15.

14. On Berardi's early career, see page 74 below

15. See Patalas, "Contributions," 254, and Scacchi, "Raggionamenti," fol. 24r. 
Table 1 Berardi's known published works (literary and theoretical works are in bold face)

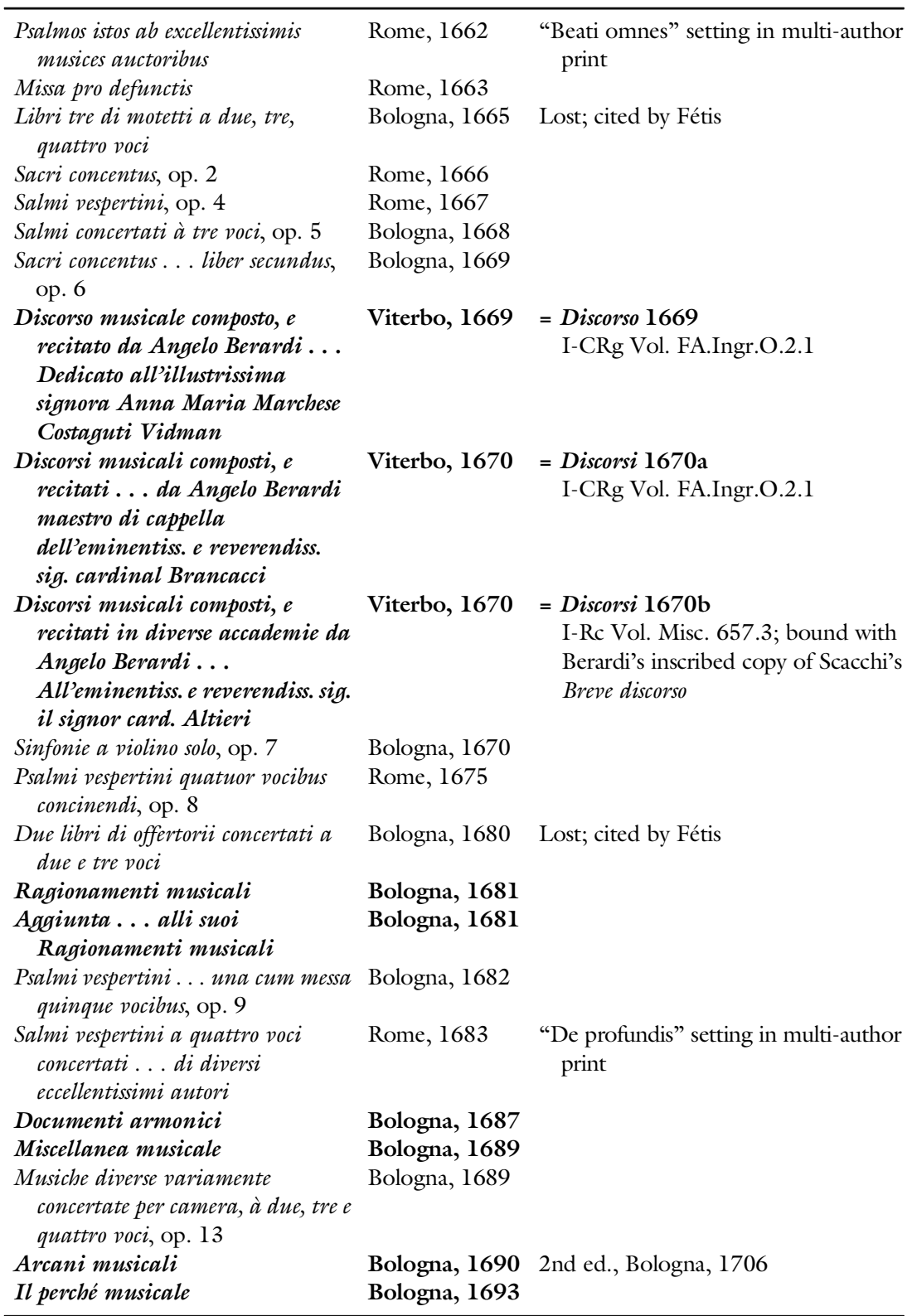


teacher Giovanni Francesco Anerio as director of the Vasa's large musical establishment, where he composed concerted polychoral works for the royal chapel and oratorios and drammi per musica for the court. ${ }^{16} \mathrm{He}$ brought himself to the notice of the wider world with the publication of a book of Masses (1633) dedicated to Władysław IV and a book of concerted madrigals (1634) dedicated to Emperor Ferdinand II. But he is chiefly remembered for two polemical writings: the Cribrum musicum ad triticum siferticum (Musical Sieve for Siefertian Wheat, 1643), which attacked Paul Siefert's compositional errors; and the Breve discorso sopra la musica moderna (1649), which attacked Romano Micheli's old-fashioned canons and staunchly defended modern music. After returning to Italy Scacchi took on several music students, but apparently published nothing further. He died in 1662, just as Berardi was embarking on his own publishing career.

Like Scacchi, Berardi began to publish musical writings about a decade after his music had first appeared in print. A detailed examination of the first of these, the Discorsi musicali (1670), sets the stage for a broad consideration of the literary production of Berardi and his contemporaries. Although the Discorsi are frequently considered lost (as they are by the New Grove), they indeed survive, and in several versions. The full version consists of three discourses presented at aristocratic academic gatherings in Viterbo. The first, Dell'origine e inventori della musica, concludes, on the basis of a preponderance of classical and ecclesiastical evidence, that music is a gift from God. The second, Della nobiltà della musica e à che fine si deve imparare, argues that music, as a science, ought to be cultivated for virtue rather than for mere pleasure. The third, In difesa della musica contro quelli che la biasimano, condemns critics of music - especially critics of musica moderna - as being at odds with the harmony of Creation. Berardi did not discuss specific composers or enter into technical matters. Even from this brief précis the reader may correctly conclude that Berardi's ideas are completely unoriginal. That goes double for his actual words.

Not by chance did Berardi, like his mentor, defend modern music. One copy of Berardi's Discorsi, in a miscellaneous volume at the Biblioteca Casanatense in Rome, is bound together with a copy of Scacchi's equally rare Breve discorso (see Figures la and $\mathrm{lb}$ ). ${ }^{17}$ This copy of the Breve discorso

16. See Patalas, $W$ kościele, w komnacie, 423-37.

17. The miscellaneous volume is I-Rc Vol. Misc. 657. The Berardi and Scacchi exemplars were both listed in the Casanatense's eighteenth-century catalogs and were already bound in a volume that included Bontempi's Nova quatuor vocibus componendi methodus. The call number listed in the early catalogs, Misc. vol. 365, still appears on a label pasted inside Vol. Misc. 657; see [Audiffredi], Bibliothecae Casanatensis catalogus librorum, 1:555, 752, and "Supplementum generale ad catalogum," fol. 459v. Oscar Mischiati reminded scholars of the Berardi exemplar around 2000; see Simi Bonini, "Angelo Berardi," 499 (though the author appears not to have consulted it herself). After I had consulted the Casanatense Discorsi in early 2011 Francesco Dall'Ara completed a study that treats this source. Unfortunately, I have not been able to see Dall'Ara's work and have arrived at my conclusions independently. 


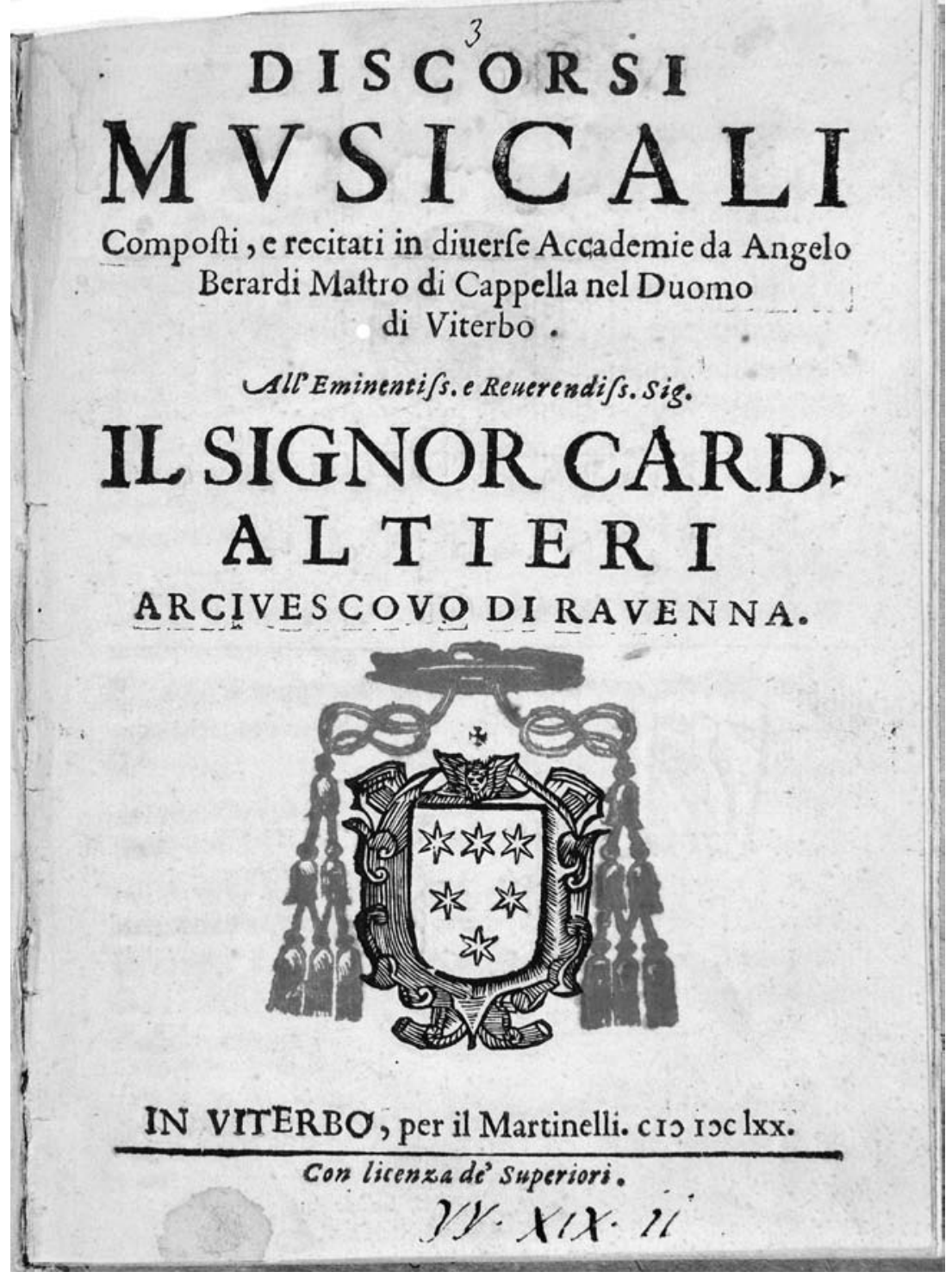

Figure la Title page of Angelo Berardi's Discorsi musicali (Viterbo, 1670), exemplar from Rome, Biblioteca Casanatense, Vol. Misc. 657.3. Used by permission. This figure appears in color in the online version of the Journal. 


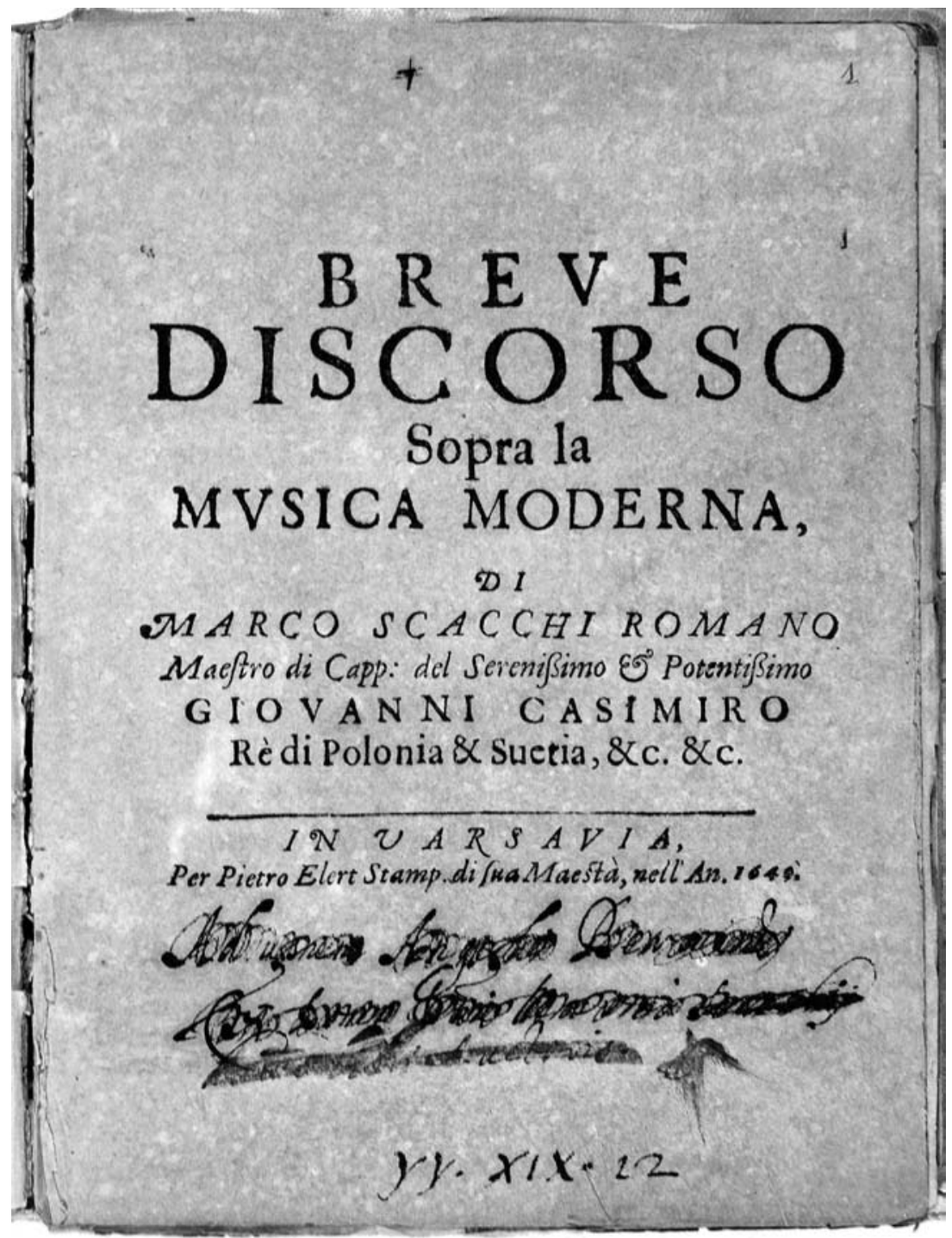

Figure 1b Title page of Marco Scacchi's Breve discorso sopra la musica moderna (Warsaw, 1649), exemplar from Rome, Biblioteca Casanatense, Vol. Misc. 657.4. Used by permission.

carries a heavily canceled inscription on the title page: "Ad usum Angeli Berardi / Ex dono Domini Marci Scacchii / h[uius libris] Auctoris" (For the use of Angelo Berardi, a gift from Mr. Marco Scacchi, author of this book; 


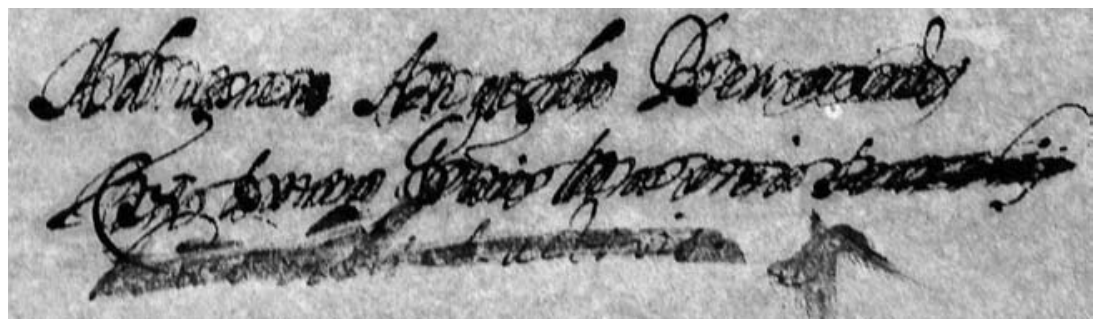

Figure 1c Title page of Marco Scacchi's Breve discorso sopra la musica moderna (Warsaw, 1649), detail, exemplar from Rome, Biblioteca Casanatense, Vol. Misc. 657.4. Used by permission.

see Figure lc). ${ }^{18}$ Berardi took "ad usum" literally: his Discorsi borrow verbatim from Scacchi's Breve discorso, among other sources (see Table 2). Berardi chose the path of least resistance, excerpting a text until he bumped against something unsuitable. At that point he switched to another source, usually one Scacchi had cited. In the third discourse, for instance, Berardi excerpted Scacchi's defense of the modern style. Here, Scacchi charged that those who would claim the authority of Saint Jerome in their criticisms of modern music had misunderstood Jerome's words. So far, so good. But Scacchi's subsequent declaration, that "Modern music does not live upon discourses alone ... [but] listens to song, and not to prose, to delight the hearing," simply would not do for a prose discourse to be delivered before a polite academy. ${ }^{19}$ At this point Berardi substituted another example of music's critics' misreading of Jerome, which he borrowed from one of Scacchi's own sources: Tommaso Garzoni's Piazza universale di tutte le professioni del mondo $(1586) .{ }^{20}$ The list of borrowings in Table 2 is not exhaustive and probably not even exact. While Berardi carefully cited classical and biblical sources and invoked "the most learned Zarlino" he was tight-lipped about Scacchi and other modern sources. ${ }^{21}$ Then, as now, there were many reasons to cite original loci instead of the convenient secondary sources upon which one actually relied. For example, Berardi probably drew material on the Spartans from a common reference work such as Laurence Beyerlinck's Magnum theatrum vitae humanae (1631) rather than from an easy familiarity with Plutarch. As Ann Blair demonstrates, the proliferation of scholarly shortcuts such as Beyerlinck's Magnum theatrum and Garzoni's Piazza universale provoked anxiety about "making

18. The inscription may be in Berardi's hand. According to Simi Bonini, Berardi himself wrote "Ad usum Angeli Berardi" on the alto and bass partbooks of Michelangelo Falusi's Responsoria (Rome, 1684) in the archives of Santa Maria in Trastevere: Simi Bonini, Catalogo, 314.

19. Scacchi, Breve discorso, fol. 1lv: "la Musica moderna non si pasce di discorsi solamente . . con attendere al canto per dilettatione dell'Udito, e non alla prosa."

20. Compare Garzoni, La piazza universale, 443-44, with Berardi, Discorsi 1670b, 14.

21. Berardi, Discorsi 1670b, 4: "Il dotissimo Zarlino." An exception is a single reference to Garzoni taken over from Scacchi. 


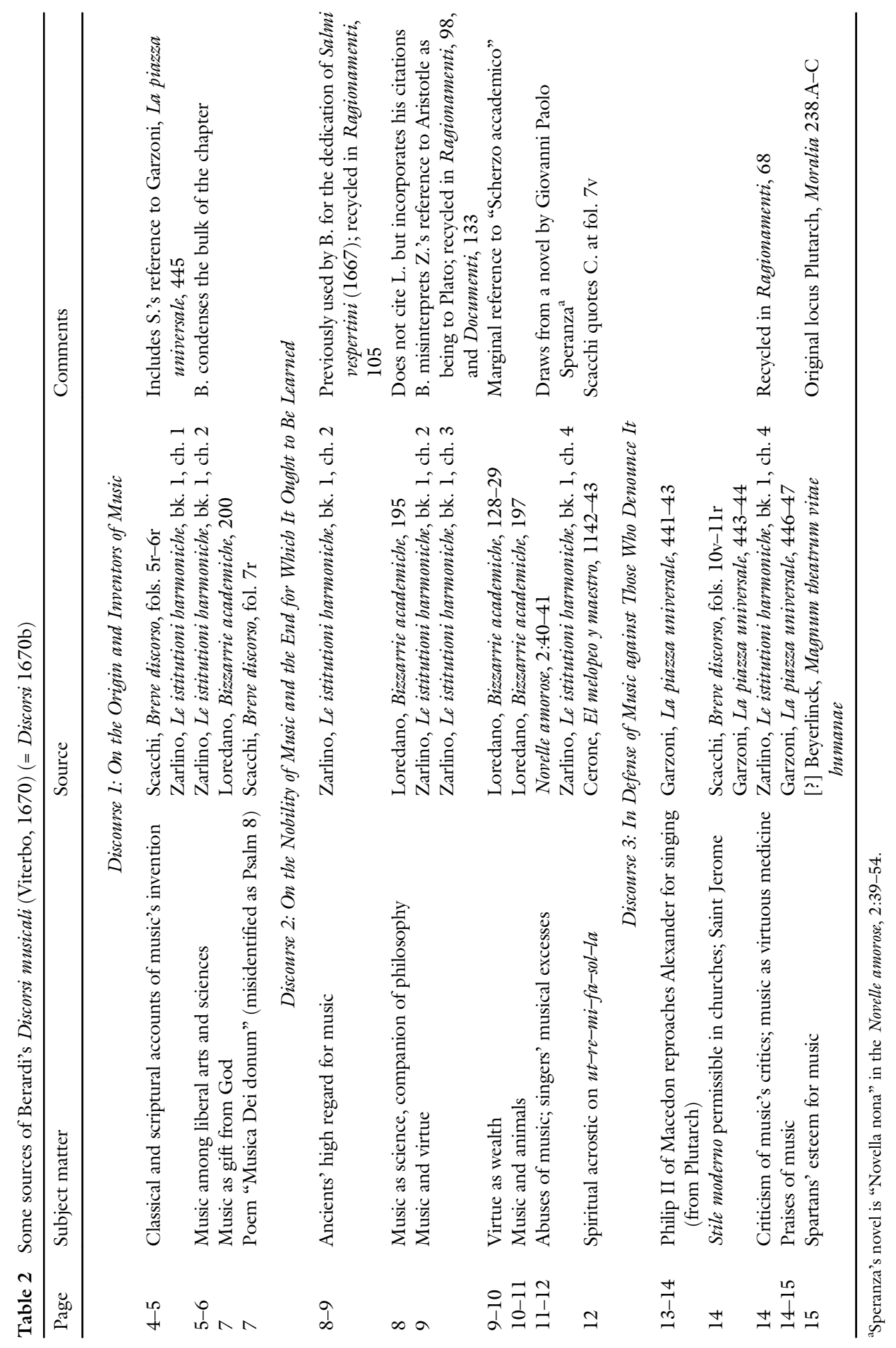


the trappings of learning too widely available."22 They enabled a Berardi to be ambiguous about his precise social position: he could present himself as having enjoyed the privileges of a class to which he did not actually belong. Berardi would have seen the social reality dramatized in the very structure of Garzoni's treatise, which arranged "all the world's professions, noble and ignoble," on a great piazza, musicians falling between sorcerers and gravediggers-three hundred pages after nobles, lawyers, and scholars. ${ }^{23}$ Through careful use of sources, especially the metaphysical reflections of Zarlino (a "masterful manipulator of his printed persona" in his own right, as Cristle Collins Judd shows), ${ }^{24}$ Berardi presented himself before the academy as more musicus than cantor. ${ }^{25}$

Although, as we shall see, Berardi recalled studying counterpoint with Scacchi, it is likely that the older composer also introduced his pupil to a wider world of musical thought. ${ }^{26}$ Borrowing and reworking these texts may also have served as a means of developing Berardi's skill at prose composition beyond the level attained in a provincial education. Perhaps, through Scacchi's encouragement or example, Berardi realized the potential value of developing an intellectual and literary persona for the career of a modern maestro di cappella.

By sheer coincidence, as I conducted my research in 2014 a second copy of the Discorsi surfaced at the Biblioteca Statale di Cremona together with two previously unknown variants. ${ }^{27}$ Berardi published the second of the three discourses in 1669 as Discorso musicale, which he recited at an academy

22. Blair, Too Much to Know, 255; see also Blair's Chapters 1 and 5 for a broader discussion of the impact of early printed reference books. Beyerlinck was a common source for musicians in this period, including Bontempi, Macchetti, and Nassarre.

23. Garzoni, La piazza universale, title page: "La piazza universale di tutte le professioni del mondo, e nobili et ignobili.” Nevertheless, Garzoni's portrait of lawyers (et al.) was not entirely flattering; see George McClure's discussion of the complexities of Garzoni's Piazza in McClure, Culture of Profession, chs. 3-4.

24. Judd, Reading Renaissance Music Theory, ch. 7, here 188. Judd shows that Zarlino earned an early reputation for learnedness, somewhat at the expense of his musical reputation; to an extent, Berardi worked in the opposite direction. On Zarlino's singular status in seventeenth-century "discourse about music," see page 92 below.

25. Some aspects of Berardi's self-presentation appeared more convincing than others. Johann Mattheson, for instance, noted that Berardi signed himself "D. Angelo Berardi" on the title page of his Documenti armonici, and while he was willing to believe that "D." signified "Don," a nobleman of some sort ("einen Edlen Herrn"), he coyly suggested that it could not mean "Doctor," apparently finding Berardi's erudition less than convincing: Mattheson, Der vollkommene Capellmeister, 248.

26. Both Berardi and Scacchi drew on somewhat unusual sources for mid-century Italian musicians, such as Pietro Cerone's El melopeo y maestro (Naples, 1613) and Hermann Finck's Practica musica (Wittenberg, 1556).

27. The three exemplars are bound together in I-CRg Vol. FA.Ingr.O.2.1, a miscellany containing tracts on religion, astrology, and astronomy. The volume is inscribed by an Augustinian monk from Cremona, Josephus Franciscus Nicolus. My study of the volume is indebted to the assistance and expertise of Francesco Cignoni of the Biblioteca Statale di Cremona. 
given by the Viterbese nobleman Pietro Boninsegni. He dedicated the Discorso to a Roman noblewoman, Anna Maria Costaguti Vidman, the dedicatee of his Salmi concertati (1668). Then, probably in early 1670, Berardi printed the first and second of the Discorsi as a single volume with a dedication to Boninsegni. The full set of three discourses was probably published last. On July 12, 1670, Berardi signed the dedication of the complete set to Cardinal Paluzzo Paluzzi Altieri degli Albertoni. That May, Pope Clement X Altieri had adopted Albertoni as nipote (nephew), a title that allowed him to accrue and spend vast riches for the papal family. Once Cardinal Albertoni became Cardinal Altieri, musicians vied for his patronage. ${ }^{28}$ Before being named nipote, Altieri had held (from 1666) the bishopric of Montefiascone, where Berardi served as maestro di cappella in the early 1660 s. $^{29}$ Berardi may have met Altieri during this period; if so, he rushed to capitalize on their acquaintance when the cardinal was adopted. He may have succeeded, since the title page bears the cardinal's arms (see Figure la). A biographical entry of 1704 states that Berardi "was promoted by Cardinal Paluzzo Altieri to maestro of the famous chapel of the Holy House of Loreto." ${ }^{30}$ Although an appointment at Loreto seems unlikely, Berardi did remain on the fringes of the Altieri family until his death. The data, however, do not quite line up: they may suggest that Berardi was a low-level client of the Altieri, or they may simply amount to a string of coincidences. ${ }^{31}$

Whatever the outcome, by offering the cardinal a set of discourses Berardi chose to present himself not as a mere musician but as a gentleman groomed for polite society. Since he needed to move quickly in order to profit from

28. Agostino Steffani sought out Cardinal Altieri, and Alessandro Stradella sought out his brother Gaspare (Paluzzo Albertoni) Altieri; see Timms, Polymath of the Baroque, 17-18, and Gianturco, Alessandro Stradella, 24.

29. Scacchi's third will, dated September 11, 1659, lists Berardi as a canon at Montefiascone; see Patalas, "Contributions," 261. Three years later Berardi's first printed composition appeared in Florido de Sylvestris's anthology Psalmos istos ab excellentissimis musices auctoribus (1662), where he is listed as maestro di cappella at Montefiascone. His next publication, the Missa pro defunctis (1663), contains no professional information. A collection dedicated to him in 1665 (Bonifatio Gratiani's Antifone della Beatissima Vergine Maria) refers to him as "Maestro di Cappella nel Domo di Viterbo"; see Simi Bonini, Catologo, 350-51, and "Angelo Berardi," 533. That Berardi dedicated his Sacri concentus, op. 2 (1666), to the bishop of Viterbo, Cardinal Brancaccio, suggests that he had only recently been appointed to the post.

30. Coronelli, Biblioteca universale, vol. 5, col. 1128: "dal Card. Paluzzo Altieri era promosso per Maestro all'insigne Cappella della S. Casa di Loreto.”

31. Nothing on Berardi surfaces in Grimaldi's studies of musical life at Loreto and none of Berardi's music is found in Loretan archives: Grimaldi, I codici musicali and La cappella musicale. Even so, since Berardi brought his earlier music to his final post at Santa Maria in Trastevere, the Loretan appointment cannot be entirely ruled out. From 1673 to 1679 Berardi served as maestro di cappella at the cathedral of Tivoli, where Altieri had held the governorship in 1671. In 1692 Berardi was elected maestro di cappella at Santa Maria in Trastevere, where Altieri had recently held the title of cardinal priest (1684-89). Shortly after assuming the position Berardi dedicated Il perché musicale (1693) to Altieri's nephew, Cardinal Lorenzo Altieri. 
the cardinal's elevation, he worked with familiar materials. Even before composing the Discorsi Berardi had borrowed from Zarlino to write the dedication for his Salmi vespertini, op. 4 (1667). When invited speak at Casa Boninsegni in 1669 he transformed that dedicatory letter into a full academic discourse. ${ }^{32}$ Perhaps needing an additional discourse soon afterward, he turned Scacchi's Breve discorso ("ad usum Angeli Berardi") into another discourse. On the adoption of Cardinal Albertoni just weeks or months later, Berardi again drew upon Scacchi's Breve discorso to write a third discourse.

Berardi presented others' work as his own, in print, three times in little more than a year, and to three different patrons. He knew how to exploit a slender resource, subsequently recycling passages from the Discorsi in his Ragionamenti musicali, Documenti armonici, and Miscellanea musicale. What Berardi lacked in originality he made up for in chutzpah. But the most important attribute of the Discorsi-and indeed of Berardi's entire literary career-is precisely that near complete absence of originality.

\section{Berardi's Inheritance: Scacchi's “Raggionamenti”}

That conclusion is confirmed by my discovery, in two Roman libraries, of several works by Scacchi. They include manuscripts of unknown works, lost or unknown publications, and the original prints of works known only through later manuscript copies. Moreover, these exemplars were likely in Berardi's possession, as their content resurfaces in Berardi's subsequent writings (see Table 3). Several important volumes of Scacchiana are found in the Casanatense, including a copy of the Cribrum musicum. Although this copy has long appeared in catalogs, its distinguishing features have been overlooked. The title page inscription identifies it as having belonged to "Angelo Berardi, student and most beloved of the author," and subsequent annotations demonstrate that Berardi used it in preparing his own treatises. ${ }^{33}$

32. Compare, for instance, Zarlino's discussion of the Pythagoreans' celestial harmonies ( $L e$ istitutioni harmoniche, bk. 1, ch. 2, 4-7), with Berardi, Salmi vespertini, op. 4, dedication, and Berardi, Discorso 1669, 7.

33. Scacchi, Cribrum musicum ad triticum siferticum, I-Rc M.V.61, title page: "Angeli Berardi Discip $u$ li ac amissimi [recte amatissimi?] Auctoris." Among the relevant annotations are Berardi's analyses of the four subjects of the first Kyrie of the Missa sine nomine (ibid., 160-61); his analyses served as the basis for a discussion of the Kyrie in his Miscellanea musicale (198-201). In the Cribrum (1-2) Scacchi gave two examples of four-voice counterpoint upon a cantus firmus that he claimed to have composed in Siefert's presence. In the Casanatense copy a third counterpoint upon the same cantus firmus is worked out below the two printed examples. Like the two printed examples, the third example includes a suggestion for a variant solution. This third example may be in Scacchi's hand; it compares well with marginal notations in I-Rsc MS G 34, discussed below. In addition, the Casanatense owns one of two known copies of Scacchi's Missarum quatuor vocibus (I-Rc Mus. 586). Although the second Agnus Dei of the Missa sine nomine was composed in eight parts, only four were printed; canonic resolutions of 
Table 3 Scacchi's "Raggionamenti" among his published works. (The table excludes works that appear in the publications of other authors.)

\begin{tabular}{|c|c|c|}
\hline Missarum quatuor vocibus & Rome, 1633 & \\
\hline $\begin{array}{l}\text { Madrigali a cinque concertati da } \\
\text { cantarsi sù gli stromenti }\end{array}$ & Venice, 1634 & $\begin{array}{l}\text { Signed at Venice, December 17, } \\
\quad 1633\end{array}$ \\
\hline $\begin{array}{l}\text { Cribrum musicum ad triticum } \\
\text { siferticum }\end{array}$ & Venice, 1643 & $\begin{array}{l}\text { I-Rc M.V.61 has annotations by } \\
\text { Berardi and possibly Scacchi }\end{array}$ \\
\hline $\begin{array}{l}\text { Lettera per maggiore informatione a } \\
\text { chi leggera il mio Cribrum }\end{array}$ & Warsaw, 1644 & $\begin{array}{l}\text { Distributed as part of Cribrum } \\
\text { musicum ad triticum siferticum }\end{array}$ \\
\hline Epistola ad amicum & $\begin{array}{l}\text { n.p., n.d. (ca. } \\
\text { 1645?) }\end{array}$ & Not part of Iudicium cribri musicum \\
\hline $\begin{array}{l}\text { Alcune considerationi musicali sopra } \\
\text { certi canoni del molto reverendo } d \text {. } \\
\text { Romano Michele romano }\end{array}$ & Warsaw, 1647 & $\begin{array}{l}\text { Lost; excerpts in I-Ra MS 500; } \\
\text { signed at Warsaw, March 16, } \\
1647\end{array}$ \\
\hline $\begin{array}{l}\text { Cantilena V. voc. \& lachrymae } \\
\text { sepulchrales, hoc est Canones... } \\
\text { honori et memoriae Johannis } \\
\text { Stobaei }\end{array}$ & Königsberg, 1647 & $\begin{array}{l}\text { I-Rc M.XIII.117: previously } \\
\text { considered lost; by Scacchi, not } \\
\text { Johann Stobaeus }\end{array}$ \\
\hline $\begin{array}{l}\text { [Epistola }] \text { ad excellentiss. D. } \\
\text { Ch[ ristopherum }] \text { Wernerum }\end{array}$ & ca. 1647 & $\begin{array}{l}\text { Uncertain whether published during } \\
\text { Scacchi's life; sole manuscript } \\
\text { destroyed in World War II }\end{array}$ \\
\hline "Raggionamenti" & $\begin{array}{l}\text { ca. late } 1648 \text { to } \\
1649\end{array}$ & Unpublished; I-Rsc MS G 34 \\
\hline Iudicium cribri musicum & Warsaw, ca. 1649 & $\begin{array}{l}\text { I-Rc M.V.61: previously known only } \\
\text { from manuscript copy; contains a } \\
\text { letter dated January } 4,1649\end{array}$ \\
\hline $\begin{array}{l}\text { Breve discorso sopra la musica } \\
\text { moderna }\end{array}$ & Warsaw, 1649 & $\begin{array}{l}\text { Berardi’s signed copy, I-Rc Vol. } \\
\text { Misc. } 657.4\end{array}$ \\
\hline $\begin{array}{l}\text { Canones nonnulli super arias } \\
\text { quasdam musicales Domini } \\
\text { Christophori Werneri }\end{array}$ & Königsberg, 1649 & \\
\hline Declaratio cantilenae quinq. vocum & Königsberg, 1650 & $\begin{array}{l}\text { I-Rc M.VI.30: previously unknown; } \\
\text { signed at Warsaw, June } 1649\end{array}$ \\
\hline
\end{tabular}

Additionally, this exemplar is bound in a larger compendium (M.V.61) of writings relating to the Scacchi-Siefert dispute. One of the prints in this volume (Iudicium cribri musicum) was previously known only from a

the others were implied. In Mus. 586 the resolutions are written out. The presence of two hands, one inexperienced and the other professional, may indicate that it was used in a pedagogical context. In fact, Berardi recalled these Masses as having been part of the "exercises that my most loving Maestro Scacchi used to require me to undertake al tavolino": Berardi, Miscellanea musicale, 196 ("dimostrationi, che mi soleva fare al tavolino il mio amorevolissimo Maestro Scacchi"). Neither of the two hands, however, appears to match those of I-Rc M.V.61. An extensive though heavily canceled inscription is still visible on the title page of Mus. 586; unfortunately, I was not permitted to view it with a lens or under different lighting. I am indebted to Christine Jeanneret for sharing with me her paleographic insights regarding the various hands. 
manuscript copy made by Padre Martini in $1745 .{ }^{34}$ A second Casanatense volume (M.XIII.117) contains a complete copy of Scacchi's Cantilena $V$. voc. \& lachrymae sepulchrales, hoc est Canones . . . honori et memoriae Jobannis Stobaei (1647). Former scholars knew of this lost work only through a manuscript fragment preserved in Poland, on the basis of which they misattributed it to Johann Stobaeus. ${ }^{35}$ A third Casanatense volume (M.VI.30) contains a hitherto unknown publication by Scacchi, the Declaratio cantilenae quinque vocum (1650), which discusses the music of the Cantilena. The richness of the Casanatense holdings makes doubly unfortunate the disappearance of several treatises by Berardi from a fourth volume. ${ }^{36}$

Although these discoveries shed new light on Scacchi, they do not radically alter his appearance. The Declaratio shows Scacchi, seven years after the Cribrum, still embroiled in the same tired dispute with Siefert. They do, however, further alter our picture of Berardi. For he used these works as he had Scacchi's Breve discorso, transposing passages from them into his own writings. In some cases, such as the Declaratio, he needed first to translate Scacchi's Latin into Italian so that the resulting prose would have a consistent tone. ${ }^{37}$

But by far the most revelatory source I have unearthed in Rome is a manuscript set of "Raggionamenti" in the Biblioteca Musicale Governativa del Conservatorio di Musica Santa Cecilia (MS G 34). ${ }^{38}$ Because neither author nor date appears in the manuscript it has been miscataloged as an anonymous eighteenth-century work. ${ }^{39}$ Careful study of the manuscript, which includes

34. See Fanti, Mischiati, and Tagliavini, Catalogo, 1:254. The copy was made on September 22, 1745, "nella Insigne e publica Libraria della Minerva"; the Casanatense exemplar is almost certainly that from which Martini worked.

35. See Palisca and Szweykowski, "Scacchi, Marco" (which gives the place of publication as Venice rather than Königsberg).

36. I-Rc Mus. 148 (formerly O.III.157), once in the possession of nineteenth-century music historian Giuseppe Baini, still contains three partbooks for Berardi's Psalmi vespertini, op. 8, and two for the Psalmi vespertini, op. 9. Although Mus. 148 should also, according to the catalog, contain exemplars of Berardi's Documenti, Miscellanea, Perché, and Arcani, the staff of the Casanatense inform me that they have gone missing indefinitely.

37. Compare, for example, Scacchi, Declaratio cantilenae, fol. 18r/Br, with Berardi, Miscellanea musicale, 175; Declaratio cantilenae, fols. 21v-22r, with Miscellanea musicale, 61-62; Declaratio cantilenae, fol. 22r-v, with Berardi, Arcani musicali, 15-16; Declaratio cantilenae, fol. 22v, with Miscellanea musicale, 61; and Declaratio cantilenae, fols. $24 \mathrm{v}-25 \mathrm{v} / \mathrm{Ev}$, with Documenti armonici, 76 (recte 67), and Arcani musicali, 17. For a musical borrowing from the Declaratio cantilenae, see page 82 below.

38. Although the manuscript is incomplete, it may be nearly complete. The first Raggionamento is missing entirely (together with some of the front matter) and the manuscript ends in mid-sentence during the tenth Raggionamento. A canceled phrase on folio $3 \mathrm{r}$ nevertheless describes the work as being "divided into ten Raggionamenti," and a phrase in the ninth Raggionamento (fol. 24r) suggests that Scacchi had nearly reached the end of the work.

39. I have not been able to trace the manuscript's provenance further back than 1877-78, when it entered Santa Cecilia as part of the collection of Alessandro Orsini (Fondo Orsini 21036). I thank Domenico Carboni, former director of the Biblioteca Musicale Governativa, for discussing with me the history of the collections. 
Table 4 Scacchi's "Raggionamenti" (ca. 1648-49): an overview of contents

\begin{tabular}{|c|c|c|}
\hline Chapter & Folio & Subject matter \\
\hline Index of authorities cited & $\operatorname{lv}-2 \mathrm{r}$ & \\
\hline Raggionamento I & & Missing; likely an attack on Romano Micheli \\
\hline Raggionamento II & $3 r-5 r$ & $\begin{array}{l}\text { Refutation of Micheli's claim to have invented } \\
\text { soggetto cavato technique ("cantilene sopra } \\
\text { le vocali") using numerous sixteenth- } \\
\text { century examples }\end{array}$ \\
\hline Raggionamento III & $5 \mathrm{r}-7 \mathrm{v}$ & $\begin{array}{l}\text { Guido of Arezzo, Saint Gregory, the } \\
\text { invention of notation, and "musica sopra le } \\
\text { vocali" }\end{array}$ \\
\hline Raggionamento IV & $8 \mathrm{r}-12 \mathrm{v}$ & $\begin{array}{l}\text { Ancient classifications of tones and modes; } \\
\text { modal affect; ecclesiastical modes, the } \\
\text { twelve modern tones }\end{array}$ \\
\hline Raggionamento V & $12 v-16 r$ & Counterpoint reduced to number \\
\hline Raggionamento VI & $16 r-20 v$ & Instruments: families, varieties, inventors \\
\hline Raggionamento VII & $20 v-23 r$ & $\begin{array}{l}\text { Superiority of musica moderna over sixteenth- } \\
\text { century counterpoint; distinctions among } \\
\text { modern styles }\end{array}$ \\
\hline Raggionamento VIII & $23 r-v$ & The human voice and its varieties \\
\hline Raggionamento IX & $23 \mathrm{v}-24 \mathrm{r}$ & Apologia for his career and works \\
\hline Raggionamento X & $24 \mathrm{r}-25 \mathrm{v}$ & $\begin{array}{l}\text { Incomplete; Willaert's "Quid non ebrietas" as } \\
\text { a refutation of Micheli's claim to have } \\
\text { invented enharmonic music }\end{array}$ \\
\hline
\end{tabular}

extensive autobiographical commentary, makes it clear that these "Raggionamenti" are Scacchi's. In addition, the content of the "Raggionamenti" (summarized in Table 4) closely resembles that of Scacchi's Cribrum musicum and Breve discorso. Although the "Raggionamenti" share a great deal with Scacchi's lost Considerationi (1647), they are separate and distinct. ${ }^{40}$ In the Considerationi Scacchi attacked Romano Micheli's canons in general, and specifically Micheli's claim to have invented canons with soggetti cavati. Pietro Della Valle, who shared Scacchi's views on the superiority of modern music, described the Considerationi as "very well written." ${ }^{41}$ Micheli, not surprisingly, described them as "long and boring" in the manuscript "Risposta fatta da me Romano Micheli" (1648). ${ }^{42}$ The "Risposta" frequently quotes and paraphrases Scacchi, noting his lapses of grammar and spelling.

40. Scacchi's Alcune considerationi musicali sopra certi canoni del molto reverendo d. Romano Michele romano was published in Warsaw in 1647.

41. Della Valle read the treatise in 1647 and recorded his comments in a diary: Della Valle, "Libri, che ho letti," fasc. 2, fol. 47r ("Buonissima scrittura"). Excerpts from the diary are transcribed in Barbieri, "Pietro della Valle," 112-15.

42. Micheli, "Risposta," fols. 10r ("una lunga, e noiosa stampa"), $11 \mathrm{r}$. Micheli published an abbreviated version of the "Risposta" as an Avviso (1650), quoted on page 113 below. The manuscript of the "Risposta" is bound in I-Ra MS 500 together with others of Micheli's writings, compositions, and papers. Micheli himself donated I-Ra MS 500 to the Biblioteca Angelica, a sign of the unusual intellectual regard (that is, for a seventeenth-century musician) in which he 
These passages offer a glimpse of the scope and content of the Considerationi, and distinguish them from the "Raggionamenti." 43 In the "Raggionamenti" Scacchi spoke of "my Considerationi" in the past tense. He remarked that he had held the position of maestro di cappella for fifteen years, that he was then in the service of Casimir IV, and that he had spent twenty-seven years in Poland. ${ }^{44}$ This places the "Raggionamenti" around late 1648 or early 1649, a year or more after he published the Considerationi but shortly before he returned to Italy. ${ }^{45}$

For our purposes, the most interesting feature of the "Raggionamenti" is their reappearance in the four treatises Berardi published between 1681 and 1690. As shown in Table 5, by 1690 he had published under his own name nearly all of Scacchi's "Raggionamenti"—a treatise that attacked Micheli for claiming the musical innovations of others as his own. Three brief examples from Table 5 are given in the Appendix. While all the loci in Table 5 involve some degree of verbatim borrowing, the examples presented in the Appendix illustrate the range of Berardi's technique from simple transposition to careful reworking. In the first example Berardi transposed Scacchi's text with few changes. In the second he pruned and polished Scacchi's original, dropping, for instance, the epithet "divine" from Palestrina's name. Still, the presence of only minor changes reveals Berardi's great indebtedness to Scacchi for his knowledge of music history. The third example, although similar to the previous two, demonstrates selective borrowing and significant intervention. In drawing upon Scacchi's discussion of Adrian Willaert's "Quid non ebrietas," Berardi not only demoted Willaert from "Divino" to mere "Musico rarissimo," but also jettisoned Scacchi's anti-Micheli polemic. This rendered Scacchi's text appropriate to the tone and style of Berardi's treatises (as we shall see), but the palimpsest remains discernible. ${ }^{46}$

Although Scacchi's 1655 will bequeathed his books and music to colleagues and students other than Berardi, Alexandra Patalas has recently offered tantalizing (though inconclusive) evidence to suggest that at least some of these materials actually passed into Berardi's hands. ${ }^{47}$ The concordances in Table 5 and the Appendix support that suggestion. MS G 34, or

held himself. Patalas transcribes portions of the "Risposta" in W kościele, w komnacie, 412-17, and discusses the polemic in "Ut oratio sit Domina."

43. Despite their similarities I find no verbatim concordances between the "Raggionamenti" and the phrases Micheli quoted from the Considerationi.

44. Scacchi, "Raggionamenti," fol. $24 \mathrm{r}$.

45. It is difficult to be more precise or completely certain: the "Raggionamenti" cite nothing published later than 1629, the manuscript is incomplete, and Micheli quoted only selectively from the Considerationi.

46. Scacchi's "Raggionamenti" end prematurely at this point, but the corresponding passage in Berardi's Documenti may preserve the missing material. Berardi also drew here upon a discussion in Scacchi's Declaratio cantilenae (fols. 19v-20r), itself heavily indebted to Artusi's L'Artusi (fols. 21r-23v (recte 22v), 31v-32v).

47. Patalas, "Contributions," 257, 262. 
Table 5 Scacchi's "Raggionamenti" and Berardi's borrowings from them

\begin{tabular}{|c|c|c|}
\hline $\begin{array}{l}\text { Scacchi } \\
\text { "Raggiona- } \\
\text { menti" folio }\end{array}$ & Subject matter & Berardi \\
\hline $3 \mathrm{r}$ & $\begin{array}{l}\text { Piccioli's canon a } 3 \text { upon the } \\
\text { syllables "Fa mi resolare la } \\
\text { scarpetta" }\end{array}$ & Documenti, 115 \\
\hline $5 r-6 r$ & $\begin{array}{l}\text { Gregory the Great, Guido of } \\
\text { Arezzo, the invention of pitch } \\
\text { notation }\end{array}$ & Miscellanea, 54-56 \\
\hline $7 v$ & $\begin{array}{l}\text { De Muris and the invention of } \\
\text { rhythmic notation }\end{array}$ & Miscellanea, 56 \\
\hline $8 \mathrm{r}-\mathrm{v}$ & $\begin{array}{l}\text { Ancient inventors of the modes and } \\
\text { tones }\end{array}$ & Miscellanea, 168-70 \\
\hline $9 \mathrm{r}$ & $\begin{array}{l}\text { Ancient ordering of modes } \\
\text { according to Euclid and } \\
\text { Aristoxenus }\end{array}$ & Miscellanea, 175 \\
\hline $9 \mathrm{r}-\mathrm{v}$ & $\begin{array}{l}\text { Ancient modes and nations } \\
\text { (Dorians, Phrygians, etc.) }\end{array}$ & Miscellanea, 173 \\
\hline $10 \mathrm{r}-\mathrm{v}$ & $\begin{array}{l}\text { Difference between tones and } \\
\text { modes }\end{array}$ & Miscellanea, 173-74 \\
\hline $11 \mathrm{r}-\mathrm{v}$ & $\begin{array}{l}\text { Twelve tones and their } \\
\text { transpositions }\end{array}$ & Miscellanea, 176-78 \\
\hline $12 \mathrm{v}-13 \mathrm{r}$ & $\begin{array}{l}\text { Tables for counterpoint at various } \\
\text { intervals }\end{array}$ & Ragionamenti, 146-48 \\
\hline $13 r-v$ & $\begin{array}{l}\text { Musical examples of counterpoint at } \\
\text { the octave, tenth, twelfth }\end{array}$ & Documenti, 119, 124-25 \\
\hline $14 \mathrm{v}$ & $\begin{array}{l}\text { Canons by Soriano ("Ave maris } \\
\text { stella") and Valentini ("Illos tuos } \\
\text { misericordes oculos") }\end{array}$ & $\begin{array}{l}\text { Documenti, } 130 \text { (recte } 132) \\
\text { Documenti, } 15\end{array}$ \\
\hline $15 \mathrm{r}-\mathrm{v}$ & $\begin{array}{l}\text { Rules for canonic writing at intervals } \\
\text { within the octave }\end{array}$ & Documenti, 90-101 \\
\hline $15 \mathrm{v}$ & $\begin{array}{l}\text { How to write a canon capable of } \\
\text { retrograde inversion }\end{array}$ & Documenti, 70 \\
\hline $16 \mathrm{r}$ & $\begin{array}{l}\text { Classification of instruments (strings, } \\
\text { winds, percussion) }\end{array}$ & $\begin{array}{l}\text { Ragionamenti, } 44 \\
\quad \text { Miscellanea, 13-14 }\end{array}$ \\
\hline $16 v-17 v$ & $\begin{array}{l}\text { Invention of the piffaro, flauto, } \\
\text { tromba }\end{array}$ & Miscellanea, 15-16 \\
\hline $17 v$ & Invention of the organ and fagotto & Miscellanea, 16 \\
\hline $18 \mathrm{r}$ & Invention of the lyre (cethara) & $\begin{array}{l}\text { Miscellanea, 16-17 } \\
\quad \text { Ragionamenti, } 46\end{array}$ \\
\hline $18 \mathrm{v}$ & Invention of the violin & Ragionamenti, 45 \\
\hline $18 \mathrm{v}$ & $\begin{array}{l}\text { Invention of the monochord, } \\
\text { tromba marina, trichord, and } \\
\text { tetrachord }\end{array}$ & Miscellanea, $17-18,37-38$ \\
\hline $2 \ln$ & $\begin{array}{l}\text { End of music (after Johannes } \\
\text { Spangenberg, Quaestiones } \\
\text { musicae, 1536), relation of theory } \\
\text { to practice }\end{array}$ & $\begin{array}{l}\text { Miscellanea, 41-42 } \\
\quad \text { Ragionamenti, 17-20,97 }\end{array}$ \\
\hline $21 v-22 r$ & $\begin{array}{l}\text { Text-music relationships in the } \\
\text { sixteenth century: Palestrina, and } \\
\text { composers in chanson prints } \\
\text { published by Susato }{ }^{\mathrm{a}}\end{array}$ & Miscellanea, 40-41 \\
\hline
\end{tabular}


Table 5 continued

\begin{tabular}{|c|c|c|}
\hline $\begin{array}{l}\text { Scacchi } \\
\text { "Raggiona- } \\
\text { menti" folio }\end{array}$ & Subject matter & Berardi \\
\hline $22 \mathrm{r}-22 \mathrm{v}$ & $\begin{array}{l}\text { Stylistic classifications in modern } \\
\text { music }\end{array}$ & Miscellanea, 41 \\
\hline $23 r-v$ & Classifications of the human voice & Miscellanea, $42-43$ \\
\hline $24 v-25 v$ & $\begin{array}{l}\text { Willaert's "Quid non ebrietas," and } \\
\text { opinions of Spadaro and Artusi }\end{array}$ & Documenti, 78-80 \\
\hline $25 \mathrm{r}-\mathrm{v}$ & Micheli’s "O voi che sospirate" & $\begin{array}{l}\text { Miscellanea, 59-62 } \\
\quad \text { Arcani, } 14\end{array}$ \\
\hline
\end{tabular}

${ }^{\mathrm{a}}$ See note 115 below.

something closely related, must have been in Berardi's possession. That almost every portion of the manuscript turns up in Berardi's writings, and that it surely represents only a portion of Scacchi's manuscripts, prompts us to ask just how many of Berardi's words are his own. ${ }^{48}$ Scacchi frequently promised ("Lord willing") to publish a full counterpoint treatise, ${ }^{49}$ though if he ever wrote one it is lost. Berardi, however, treated counterpoint extensively and in a manner similar to his mentor (from whom, as the first example in the Appendix shows, Berardi took much material on counterpoint word for word, and example for example). Berardi assured readers that his Miscellanea would "not stray at all from the teachings of my most loving master and famous teacher Marco Scacchi," and that the studies of the Documenti represented his and Scacchi's "ordinary pastime." ${ }^{50}$ In light of MS G 34 Berardi needs to be taken far more literally than he has been. Table 5 shows that he did indeed take musical examples for his Documenti from Scacchi's "Raggionamenti." Scacchi's counterpoint treatise may be preserved among Berardi's published writings.

Might study of Berardi's music reveal something similar? The new sources do not so far warrant a wholesale reassignment of Berardi's compositions to Scacchi. They do, however, offer suggestive rereadings of evidence that has been hidden in plain sight, as well as giving further glimpses of the ways in which Berardi alternately gave or took credit in order to advance his persona. In the Salmi concertati (1668) he attributed a single composition to

48. For instance, Berardi's discussion of Josquin's Missa Hercules Dux Ferrariae is likely indebted to Scacchi's Considerationi; compare Berardi, Documenti armonici, 114, with Micheli, "Risposta," fol. 15v.

49. See, for example, Scacchi, "Raggionamenti," fol. 23v: "spero di farlo, se Dio me concederà tanta Vita"; see also ibid., fols. 12v, 24r, and Scacchi, Declaratio cantilenae, fol. 25v/Ev.

50. Berardi, Miscellanea musicale, 168: "non allontanandomi punto dall'insegnamenti del mio amorevolissimo Maestro, \& insigne professore Marco Scacchi”; Berardi, Documenti armonici, 11: "il nostro ordinario trattenimento" (a longer passage is translated on page 86 below). 
"Mr. Giovanni Gasparo Probstat, student of the author." ${ }^{51}$ In this case Berardi was probably obliged to acknowledge the aristocratic composer explicitly, but doing so also worked to his advantage: he portrayed himself as a successful musician who enjoyed a certain intimacy with pupils of high social rank. A murkier case occurs in his Sinfonie a violino solo, op. 7 (1670). The inscription "M.S." (omitted from the critical edition without explanation) appears in large type above the anomalous final piece of the collection. ${ }^{52}$ It will by now be obvious to what - or rather, to whom- "M.S." may refer. If it is indeed an attribution, it is both direct and deliberately ambiguous, especially since each of the previous five pieces is headed by an allusive epigram (e.g., "In inconstancy shall I be faithful"). ${ }^{53}$ Berardi had already placed "M.S." above the final composition in his Missa pro defunctis (1663), published the year after Scacchi's death-"Vota cano trinitati," a three-voice Trinitarian canon on a soggetto cavato. ${ }^{54}$ This canon does not appear among Scacchi's surviving compositions, but could possibly derive from his polemic against Micheli's three-voice Trinitarian canon on a soggetto cavato. Berardi republished this canon twice, both times without that quiet "M.S."55 Perhaps he composed it as a memorial to his recently deceased teacher; perhaps Scacchi composed it, and it gradually "became" Berardi's. The discovery of Scacchi's Declaratio and Cantilena suggests that the latter scenario is, at the very least, plausible. Among other materials, Berardi drew from them artful dedicatory canons for Il perché musicale and the Arcani musicali, demonstrations of recondite contrapuntal learning that could set him apart from the pack. In both cases we read that "Angelo Berardi gave, offered, and dedicated" them to noble recipients ("Angelus Berardus Dedit Donavit Dedicavit"). ${ }^{56}$ It serves admirably as a claim of authorship_-without actually amounting to one.

51. Berardi, Salmi concertati, 39: "Del Sig. Gio. Gasparo Probstat. Scolaro dell'Autore.”

52. Berardi, Sinfonie a violino solo, 83. A comparison of Berardi's instrumental music with Scacchi's is beyond what the current state of the sources permits. In addition to being the only piece without an epigram, however, the final work in op. 7 demonstrates stylistic and generic features that further distinguish it from the rest of the collection. It is the only work designated "capriccio per camera" rather than "sinfonia." Moreover, the standard movement types of the sinfonia (e.g., Adagio, Vivace, Balletto) stand in marked contrast to the unusual types found in the capriccio (e.g., "Tempo furio di sarabanda presto," "Tempo inglese," "Perfidia replicata," "Aria todesca").

53. Ibid., 54: "Nell'incostanza fedel sarò" ("Canzone quarta").

54. Berardi, Missa pro defunctis, 16.

55. Berardi, Aggiunta, 34, and Documenti armonici, 115. On the controversy over canons, see pages 112-13 below.

56. Compare Scacchi, Declaratio cantilenae, fol. 17v, with Berardi, Il perché musicale, 6; and Scacchi, Cantilena, D3v, with Berardi, Arcani musicali, 4. Berardi altered the rhythms of both in order to accommodate the text. In addition, Scacchi's setting of "Domine Deus" (Declaratio cantilenae, fol. 25v/Ev) reappears in Arcani musicali, 17. Berardi gives no attribution for this piece; the two preceding it, however, he credits to Romano Micheli and Alfonso Dalla Viola. Finally, in the Miscellanea musicale (181-82) Berardi borrowed without attribution 
Whatever a thorough comparison of the two composers' music might yield, for our purposes Berardi's indebtedness to Scacchi ought to be clear. Berardi received a great deal from his teacher beyond the counterpoint lessons for which he professed eternal gratitude. Scacchi introduced his pupil to a wide range of musical literature. He provided, knowingly or not, the books and manuscripts that became the raw materials for Berardi's authorial (and perhaps compositional) career. And he demonstrated the potentials and perils of cultivating a literary persona. We turn now to the choices Berardi and his contemporaries made in fashioning themselves as writers. Along the way, I will present additional examples of borrowing drawn from a wide variety of musical writings in order to complicate them as mere "sources" of musicological "information"-and, ultimately, to ask of them more significant questions.

\section{Plagiarism; Or, the Making of a Gentleman}

Berardi possessed nearly all of Scacchi's publications and could use them at will. But he grew cautious as he graduated from short discourses to booklength treatises. After his early Discorsi musicali his unacknowledged borrowings from Scacchi tended to come from rarer prints with which readers would be unfamiliar, and from a manuscript to which only he had access. At the same time, Berardi left his Roman publishers and established a relationship with Giacomo Monti in Bologna. Berardi forged good relationships with publishers throughout his career, ${ }^{57}$ moving to Monti at a propitious moment, just as the latter was emerging as a leading music publisher in Italy and on the international market. ${ }^{58}$ Over the course of twenty-five years Berardi published about a dozen literary and musical prints almost

two examples of four-voice counterpoint from Scacchi (Cribrum musicum ad triticum siferticum, 84-86).

57. Roman music publisher Amedeo Belmonti dedicated three prints to Berardi: two posthumous publications of music by Bonifatio Gratiani, Antifone della Beatissima Vergine Maria, op. 13 (1665), and Psalmi vespertini, op. 5 (1666), and an anthology of motets by Roman composers edited by Giovanni Battista Caifabri, the Sacras cantiones... secunda pars (1667). Berardi was not yet well known, so it is difficult to account for these dedications; perhaps Berardi provided Belmonti with editorial assistance. In 1670 Monti adopted for his firm's insignia an emblem that Berardi claimed to have designed for his Sinfonie a violino solo (see note 97 below). I suspect Berardi's complaint about this (in his Ragionamenti, published by Monti) to be somewhat disingenuous and intended for literary effect. In fact, the borrowed emblem may actually attest their good relationship. In his epistolary treatise Il perché musicale (28) Berardi included a friendly letter to Giuseppe Antonio Silvani, the musically trained son of Monti's business partner.

58. On the output of Monti and his successors, see Cipollone, "I Monti." On the balance of patronage and sales, see Barnett, Bolognese Instrumental Music, 19-22, and Linden, "Profit, Patronage." On the financing, print runs, and sales of Monti's successor Silvani, see Linden, "Profit, Patronage," "Early Eighteenth-Century Music Type," and (with reference to sales of Berardi's treatises) "Sellers and Buyers." 
exclusively with Monti and his successors. He made authorial choices with an eye to crafting salable product for a broad profit-driven market. To see how an accusation of plagiarism could imperil an author's reputation in the marketplace Berardi needed to look no further than the controversy surrounding another recent Monti publication, Giovanni Maria Bononcini's Varii fiori del giardino musicale (1669). Accused of stealing learned canons, Bononcini publicly promised to defend himself in a treatise, Musico prattico (1673). There, he demonstrated that he was sufficiently skilled to bave been capable of composing the pieces he had allegedly stolen. ${ }^{59}$ But if Berardi took a lesson from Bononcini it was one of caution rather than abstinence. In constructing his persona Berardi deftly employed strategies ranging from explicit acknowledgment to ambiguity, omission, and dissembling. Nor does a brief glance at his contemporaries reveal any uniform practice or opinion with respect to literary or musical borrowing.

One of the earliest writers to cite Berardi was Zaccaria Tevo (Il musico testore, 1706). Like Berardi, he possessed an unpublished manuscript treatise by his late teacher, Francesco Maria Angeli. Unlike that of Berardi, his self-presentation took the form of the punctilious bibliographer: "I have faithfully quoted the texts [of my sources]; therefore do not be surprised if you find a word spelled at times with a double consonant and at other times without, or now with an ' $\mathrm{H}$ ' and now without, because I have found them written thus, and have not altered them but transcribed them as they were."60 Tevo's practice was certainly more scrupulous, not necessarily more scholarly: leading scholars were not necessarily so scrupulous. The protagonist of Johann Kuhnau's satirical novel Der musicalische Quack-Salber (The Musical Charlatan, 1700) committed fraud ("pure ein falsum") in palming off others' music as his own. Somewhat more respectable, the narrator opined, was "learned plagiary" ("gelehrtes plagium"), in which one borrowed just a phrase or two to stimulate inventio. ${ }^{61}$ But Kuhnau was writing fiction. In real life the learned found that inventio often required more than just gentle stroking. Michael Maier, as Loren Ludwig demonstrates, lifted the more competently composed canons of his Atalanta fugiens (1618)

59. Bononcini rebutted the charges in a manuscript "Discorso musicale" (ca. 1669-70) and in the dedication to his Arie, correnti, sarabande, gighe, \& allemande, op. 4 (1671), where he spoke of the Musico prattico as being ready for the press. In an article on the part played by this treatise in Bononcini's self-fashioning Gregory Barnett demonstrates the originality of Bononcini's modal thought and the esteem in which later musicians held it. Although our conclusions are by no means contradictory, Barnett considers the plagiarism controversy to have been a less significant motivating factor. Barnett, "Giovanni Maria Bononcini."

60. Tevo, Il musico testore, "Benigno, e cortese lettore": "portandone fedelmente li testi, onde non ti maravigliare se troverai scritto un vocabolo alle volte con lettere geminate, \& altre volte nò, come pure tal'hora con l'H, e tal'hora senza, perche ciò sarà à causa di haverli trovati così, e non si sono in nulla alterati, mà rapportati come stavano." Tevo credits Angeli at 230, 268, 284, 299, 327; Angeli's manuscript survives as "Sommario del contrapunto" (I-Bc C.52).

61. Kuhnau, Der musicalische Quack-Salber, 164. 
from John Farmer's Divers and Sundry Waies (1591). ${ }^{62}$ Juan Caramuel y Lobkowitz clipped modal paradigms from a printed copy of Adam Gumpelzhaimer's Compendium musicae and literally cut-and-pasted them into the manuscript of his "Musica."63 Athanasius Kircher pilfered material for his Musurgia universalis (1650) with a mixture of subtlety and boldness. He lifted a long passage on Pythagorean musical philosophy from a title on the Index of Prohibited Books - Kepler's Harmonices mundi (1619)—which he duly attacked several hundred pages later. ${ }^{64}$ (Which, if either, gives the truer picture of Father Kircher's views?) And he borrowed almost the entirety of his contrapuntal teachings from the Specchio secondo di musica (1631) of Silverio Picerli, to whom he briefly acknowledged his indebtedness. ${ }^{65}$ By modern standards, this fig leaf hardly covers a sixty-page proboscis.

Perhaps also by the standards of Kircher's contemporaries. At the very moment when Kircher was assembling his Musurgia, his Jesuit colleague Sforza Pallavicino-just down the hall at the Collegio Romano-distinguished the "ignominious" and "servile" practice of plagiarism from the respectable practices of imitation and emulation in his Considerazioni sopra l'arte dello stile e del dialogo (1646). ${ }^{66}$ Another Jesuit, Daniello Bartoli, with whom Kircher later clashed on matters musical and scholarly, turned to recent musical scholarship to unmask a common justification for plagiarism in his Dell'huomo di lettere difeso et emendato (1645). Kepler, Mersenne, and Galilei had explored the phenomenon of two strings sounding sympathetically. This mystery, Bartoli averred, was altogether easier to resolve than "how it could be that two brains, by sympathetic agreement, would choose the very same topic [and] explain it in the very same way, without differing in a single accent or a single word." 67

But for Berardi there was no mystery. The ideal friendship attained "unity in plurality." "It is miraculous," he continued, "that two people become one

62. Ludwig, "'Waies' and 'Meanes." Since first presenting his findings in 2014 Loren Ludwig has kindly shared with me the results of subsequent research, including the possibility that Atalanta contains a veiled acknowledgment of Farmer's work.

63. Compare Gumpelzhaimer, Compendium musicae, ch. 10, with Caramuel y Lobkowitz, "Musica," bk. 3, art. 2, in which Caramuel expanded Gumpelzhaimer's abbreviated text into serviceable Latin prose.

64. Kircher, Musurgia universalis, 1:533-34 (cf. Kepler, Harmonices mundi, bk. 3, 2-4), 2:366-67. Kircher's practice of excerpting from others' writings with varying degrees of attribution did not pass unnoticed by his Jesuit colleagues. Honoré Fabri, in his prepublication review of the third edition of Kircher's Magnes (1654), warned Kircher to cite his sources "so that there might be no suspicion of plagiary": "Censurae Librorum," fol. 393r (Rome, August 14, 1652) ("ne sit aliqua plagii suspicio, illos authores appellare deberet, a quibus haec accepit").

65. Kircher, Musurgia universalis, vol. 1, Praefatio 2 (no page numbers) and 328, 383; see also Beretta, "Introduzione," xxiv n42.

66. Pallavicino, Considerazioni, chs. 11-13, here 147: "ignominioso . . . servile."

67. Bartoli, Dell'huomo di lettere, 141: “com'esser possa, che due cervelli per via di simpatico consentimento s'accordino a scegliere uno stesso argomento, a spiegarlo colle medesime forme di dire, senza divario ne pur d'un'apice, non che d'una parola." 
single person and, [although] each has his own heart and soul, live in the heart, and with the soul, of the other." Friends are but two well-tuned lyres; touch one, and the other sings the same tone. ${ }^{68}$ How could Berardi not have copied Scacchi! (Or for that matter, Emanuele Tesauro, from whom Berardi took those words, as we shall see.) ${ }^{69}$ Berardi's seamless interweaving of his words with Scacchi's resembles the ideal friendship that he claimed to have attained with his mentor:

In my flourishing youth, although I was a canon, and maestro di cappella in a notable city, I placed myself completely under the tutelage and direction of Marco Scacchi (of blessed memory), formerly maestro di cappella of the kings of Poland for thirty years [sic]. This celebrated virtuoso retired to the city of Gallese, ancient home of his ancestors, because he was quite advanced in age, and perhaps also to enjoy the peace and quiet that cannot so easily be found amid the noise of court and among weighty duties and affairs. These studies were our ordinary pastime, and because I believe they may be pleasing to professors and useful to young students, I have undertaken to write these Documenti. Being myself hardly worthy of consideration, I have no aim but to sacrifice my life among the inkwells, so that from these black blots [ombre, literally "shadows"] will shine more brightly the affection I bring to music, the gratitude I owe to the ashes of my dear master, and my burning desire to spare no labor in serving my neighbor in all that depends upon the weakness of my poor talent and nature. ${ }^{70}$

This Ciceronian idyll presents the full panoply of classical elements: the ancestral estate, retirement from urban court to country otium, fealty to the beloved tutor, honor for his ashes. ${ }^{71}$ Their studies unfold in an atmosphere

68. Berardi, Ragionamenti, 11-13: “. . . l'unità nella pluralità. Cosa miracolosa è divenir due soggetti un sol soggetto, \& havendo ciascheduno il proprio cuore, e la propria anima, vivere l'uno nel cuore, e con l'anima dell'altro. ... Di due Cetere, accordate all'istesso tuono, se una si tocca, l'altra per se stessa consona."

69. Cf. Tesauro, La filosofia morale, 488-90; see also Berardi, Arcani musicali, 7.

70. Berardi, Documenti armonici, 11: "Nella mia più florida gioventù, con tutto ch'io fossi Canonico, e Maestro di Capella in Città riguardevole, mi sottomessi intieramente alla scuola, e direzzione della sospirata memoria di Marco Sacchi [sic], già Maestro di Capella de i Monarchi di Polonia, per il corso d'Anni trenta: Si ritirò questo celebre Virtuoso nella Città di Gallese nido antico de suoi antenati, per essere avanzato assai nell'età, e forsi anco per godere quella quiete, $\mathrm{e}$ pace, che non si può rintracciare così facilmente frà i rumori delle Corti, e frà l'occupationi, \& affari de gravi impieghi. Questi studii erano il nostro ordinario trattenimento, e perche stimo che possino esser grati a i Professori, e d'utile a i Giovani studiosi, hò intrapreso à scrivere questi Documenti. Essendo io il minimo non hò altro sentimento che di sacrificare la mia vita frà gl'inchiostri, acciò con quell' ombre maggiormente risplenda l'affetto, che porto alla Musica la gratitudine, che devo alle ceneri del mio caro Maestro, \& il desiderio ardente che tengo di non perdonare à fatica per servire al mio Prossimo in tutto quello che può deprendere [sic] dalla debolezza del mio povero ingegno, e talento."

71. As Brian Vickers shows, from antiquity through the eighteenth century otium was viewed with suspicion as a corrupting form of leisure. Cicero argued that his own otium was justified, as it allowed him to produce literary works beneficial to his fellow men. Vickers, "Leisure 
of edifying and productive leisure. A reader might reasonably conclude from Berardi's description that Scacchi was a nobleman. True friendship itself marked high social class; spiritual rather than corporeal, devoid of selfinterest, it differed qualitatively from the "friendship" of artisans, tradesmen, and peasants: ${ }^{72}$

That true and loyal friendship that I always professed during the life of my dear lamented Scacchi I have preserved inviolably after his death, obliged by the highest law of true friendship: that he who loved his friend in life, will also love him in death, such that death has no power to break the bond of true friendship. For if the spiritual faculties die with the body in the same manner as the corporeal faculties, I would concede that, death being the ultimate limit of human things, Fate would have cut with the same shears the bond of life and of love. But since the intellect and will reside in the soul, it is here that the spiritual habits rest, true friendship among them. It would be a great injustice in love if the deceased loved the living and the living did not likewise [love] the deceased, and if the one ceased to love when the other ceased to live. The living must therefore, with the remembrance of the [deceased's] virtuous actions, call his friend into life. I, to perform this duty, reveal once more the difficult musical exercises woven by the celebrated pen of this author, who never spared himself weariness or discomfort in communicating these artifices to me. I will always be proud to tell the world that perfect friendship must resemble eternal fire, which, once lit upon the altar of the heart, never dies but shines inextinguishably. ${ }^{73}$

Huh? Is this the same Scacchi who compared Paul Siefert to an ignorant dog? Who claimed that Siefert composed "like an ass," producing music of "a dryness, and unprecedented aridity that . . . provokes disgust and great

and Idleness." Berardi expressed a similar ambivalence toward unbounded otium in the Aggiunta (13-14), but here he emphasized Scacchi's service to him and (through his publication of the Documenti armonici) to the public.

72. See Tesauro, La filosofia morale, bk. 20, 482; see also Pallavicino's stronger formulation in Del bene, 644 .

73. Berardi, Documenti armonici, 63: "Quella vera, e leale amicitia, che hò sempre professato in vita al mio caro, e sospirato Scacchi, quella medema li conservo inviolabilmente doppo morte, obligando l'ultima legge della vera amicitia, che chi amò l'amico in vita, l'ami anche defonto, tanto più che la morte non hà forza di sciogliere il vincolo della vera amicitia, poiche se le facoltà spirituali morissero col corpo, in quella maniera, che muoiono le facoltà corporee, concederei, che essendo la morte l'ultima linea delle cose humane, la Parca dovesse con la medesima forbice recidere il legame della vita, e dell'amore; mà restando nell'anima l'intelletto, e la volontà, in questa restano gl'habiti spirituali, frà quali si turba [recte trova] la vera amicitia. Sarebbe grand'ingiustitia in amore, che l'estinto amasse il vivente, \& il vivente, non corrispondesse all'estinto, e che l'uno havesse finito d'amare, quando l'altro finì di vivere. Deve dunque il vivo con la rimembranza dell'operationi virtuose rivocare in vita l'amico, \& io per adempire questo precetto paleso di nuovo i studii laboriosi della Musica, tessuti dalla penna famosa di questo Autore, il quale mai hà perdonato nè à fatica, nè ad incomodo, per comunicarmi questi artificii. Mi glorierò sempre, che il Mondo sappia, che la perfetta amicitia deve assomigliarsi al fuoco eterno, che una volta lacceso $[$ sic $]$ sopra l'altare del Cuore, mai più si smorza, mà inestinguib[il]mente risplende." 
boredom in the listener"? ${ }^{74}$ And who, having received Micheli's support, turned his guns on him as well? ${ }^{75}$

In recomposing Scacchi's writings, Berardi recomposed Marco Scacchi. We need not doubt Berardi's sincerity or his friendship with Scacchi. We may even suspect this to have been Berardi's sincerest act of friendship toward his beloved teacher. But Scacchi's actual literary persona-prickly, fixated on minutiae-would have been a briar in Berardi's locus amoenus. Despite the unquestionable importance of Scacchi's Cribrum musicum and Breve discorso for modern scholars, they do not appear to have had many contemporary readers beyond a coterie of professional musicians. ${ }^{76}$ Scacchi did not make the leap from musician to literary gentleman-if, indeed, he ever aimed to. In this respect, to judge only by the number of surviving copies of his work Berardi was more successful. ${ }^{77}$

In recomposing Scacchi, Berardi also recomposed himself. Readers never see Maestro Berardi swear at disobedient choirboys or suffer the frustrations of a provincial chapel master. ${ }^{78} \mathrm{He}$ cast his writings in polite genres: the academic discourse (Discorsi musicali), the dialog (Ragionamenti musicali, Aggiunta, Arcani musicali), the epistolary treatise (Il perché musicale). All depended upon a common conceit: conversation between dear friends and like-minded literati.

How different were the communities and conversations staged by Scacchi. In the Cribrum musicum, for instance, he tendered Siefert an olive branch in the form of canons composed by more than four dozen members of the Polish royal chapel: "Finally, my dear Paul, I offer you the gifts that have been composed for your sake by the whole company of musicians of this famous royal chapel, so that you might clearly recognize our goodwill toward you: since we all, on account of our deep love for you, want nothing more than to see you brought into the light of musical knowledge." 79

74. Scacchi, Cribrum musicum ad triticum siferticum, $\$ 3 \mathrm{v}-[\$ 4 \mathrm{r}]$ : "Asinescamente"; "una seccagine, \& arridezza inaudita, che . . rendono nausea, e fastidio grande all' Auditore."

75. Letter from Scacchi to Micheli of January 6, 1646, quoted in Micheli, "Risposta," fols. $23 \mathrm{r}-24 \mathrm{v}$.

76. The Cribrum musicum has been translated into both English (Scacchi, Cribrum musicum, ed. and trans. Boyd) and German (Scacchi, Cribrum musicum, ed. and trans. Heinemann). The Breve discorso has been translated twice into English (Scacchi, Brief Discourse, trans. Palisca, and Brief Discourse, trans. Carter) and once into German (Scacchi, Iudicium cribri musicum, ed. and trans. Heinemann). Claude Palisca traces the influence of Scacchi's stylistic distinctions in the writings of later musicians, including Berardi, in Palisca, "Genesis of Mattheson's Style Classification."

77. Compare, for instance, the library holdings for prints of Scacchi and Berardi given in Patalas, W kościele, w komnacie, 419-22.

78. On the travails of a maestro di cappella, see Gianturco and Boccaccio, "Teofilo Macchetti," 414, and Ciliberti, Antonio Maria Abbatini, 423-26.

79. Scacchi, Cribrum musicum ad triticum siferticum, 204: "Nunc demum tibi, mi Paule, Xenia, quae à tota corona Musicorum inclytae huius Capellae Regiae in tui gratiam sunt composita, offero, ut nostram erga te benevolentiam clarius agnoscas: siquidem omnes ac singuli 
Scacchi's olive branch had a spear's point, since he deployed friendship as a weapon by which to isolate and humiliate a defeated opponent: all the king's men stand together against Siefert. ${ }^{80}$ Such tactics arguably speak less to the private man than to the public figure. Scacchi, director of a large court musical establishment, was a visible client of a powerful monarch, Władysław IV. At stake in a public dispute was his own honor as well as that of his patron, and both demanded tenacious defense. ${ }^{81}$ Vasa largesse stood behind the sumptuous edition of Scacchi's Masses, printed in large choirbook format. Berardi, on the other hand, had no such steady relationship with a powerful patron; ${ }^{82}$ his prints were more modest and dependent upon sales. ${ }^{83}$ A broad audience might take less interest in a polemic involving questions of mode and counterpoint that Gregory Barnett rightly describes as "matter[s] of professional integrity," so Berardi papered over professional infighting, both Scacchi's and that of the musicians of Bologna's Accademia Filarmonica. ${ }^{84}$ The polemic against Corelli's parallel fifths, for instance, was led by one of the Filarmonica's founders, Giovanni Paolo Colonna. In this case Berardi placed himself above "minutiae" and treated the warring parties with charity and indulgence. ${ }^{85}$

nostrùm ob singularem tui amorem nihil magis exoptant, nisi ut ad lucem doctrinae Musicae te deductu $m$ videant."

80. Likewise, in Iudicium cribri musicum he presented letters from about a dozen sympathizers.

81. Since Siefert had charged that Scacchi's employment was a "great embarrassment" to Władysław, Scacchi explicitly staged the Cribrum as a defense of his and Władysław's honor: Scacchi, Cribrum musicum ad triticum siferticum, "Clarissimo . . . D. Casparo Forstero" and, at $\$ r$, Lettera per maggiore informatione. On honor and patronage in intellectual court disputes, see Biagioli, Galileo, Courtier.

82. In addition, Berardi seems to have had difficulty in securing steady musical employment in the years 1683-89. During this time he was passed over for at least one position (see Liberati, Lettera, 35), and the maestro di cappella at the cathedral of Viterbo lodged an official complaint with Bishop Urbano Sacchetti to the effect that Berardi was infringing upon his prerogatives by taking casual musical employment in several city churches (see De Angelis, "Paolo Agostini di Vallerano," 22). This episode may account for Berardi's dedication of the Miscellanea musicale to Sacchetti the following year.

83. In Vincenti's catalog of 1658 Scacchi's Cribrum was among the firm's more expensive items, while in the Monti-Silvani catalogs Berardi's treatises were among the cheapest items; see Vincenti, Indice di tutte le opere di musica, and Mischiati, Indici, cataloghi e avvisi, 264-313. Berardi's Psalmi vespertini, op. 8 (1675), includes a notice from publisher Giovanni Angelo Mutio advertising his advantageous terms for composers. Mutio's statement testifies, paradoxically, to the real financial risks entailed for both publishers and composers- especially composers who, like Berardi, lacked a wealthy patron. See Linden, "Profit, Patronage."

84. Barnett, "Giovanni Maria Bononcini," 245, referring to the disputes between Scacchi and Siefert and between Giulio Cesare Arresti (a founder of the Filarmonica) and Maurizio Cazzati. Cazzati's Risposta alle oppositioni fatte dal Signor Giulio Cesare Arresti (1663), a technical polemic directed to an audience of professional musicians, offers another excellent example of what Berardi attempted to transcend in his own writings.

85. Berardi, Il perché musicale, 29-30: "Hora lasciamo queste minutie" (30). For the documents of the Corelli-Colonna dispute, see Liberati et al., "Diverse lettere." How carefully 
Berardi the man may have been kind in real life. Yet, in an era in which patronage encouraged defensive (even aggressive) postures, Berardi the author cast himself in the literary role of Friend and Nice Guy. He published his private correspondence to friends and explicitly identified himself as the characters Felice and Flavio in his dialogs. In 1681 Felice warned that, while utility might result from friendship, it must never be a goal: "the lone fruit of friendship must be love." 86 In 1690 Flavio cautioned that "the love in friendship does not consist in loving a friend for gain." ${ }^{87}$ And in the role of "Berardi," having condemned the ingrate who would feign friendship for gain, the composer reminded a correspondent, "You know that lying and deceit are utterly foreign to my nature." ${ }^{88}$ What we make of this depends on what we make of the uncredited borrowings tallied in Table 5, and of borrowing in general. In any event, contemporaneous accounts suggest that Berardi projected this character convincingly enough to benefit his musical reputation. Antimo Liberati observed that Berardi displayed his musicianship "more to make known his rare virtue than out of a desire or need for money." $" 89$ Likewise, the author of an encyclopedia entry of 1704 praised Berardi's musicianship and remarked, "That which increased the reputation of his expertise was the goodness and dignity of his manner."90

By setting himself above mere technical detail and discoursing on friendship Berardi crafted a way of talking about music that sounded learned without sounding pedantic. ${ }^{91}$ Here again he needed a little help, and he found it

Berardi negotiated this dispute can be seen in $I l$ perché (where his defense of Corelli follows a letter in which he praises Colonna) and in the Miscellanea (where he praised Corelli as "Orpheus of our times" and dedicated a chapter to Colonna): Berardi, Il perché musicale, 28-30; Berardi, Miscellanea musicale, 45 ("nuovo Orfeo de nostri giorni"), 78-81.

86. Berardi, Ragionamenti musicali, 14: "E vero, che il solo frutto dell'amicitia deve essere l'amore, mà, se bene l'amicitia non segue l'utilità, l'utilità nondimeno segue l'amicitia."

87. Berardi, Arcani musicali, 9: "non essendo amore d'amicitia amare l'amico per riceverne beneficio."

88. Berardi, Il perché musicale, 24: "Ella sà il mio genio totalmente alieno dal fingere, \& ordire inganni." There is a touch of humor here, as Berardi plays upon the musical meaning of "inganno."

89. Liberati, Lettera, 35: "più pe[r] far conoscere [la sua] rara vir[t $\mathrm{t}$ ù, che per il desiderio ò necessità del lucro."

90. Coronelli, Biblioteca universale, vol. 5, col. 1128: "Ciò che poi accresceva il credito della sua perizia, era la bontà, e gravità de' suoi costumi.”

91. An instructive example is found in a web of borrowings among several theorists. Lodovico Zacconi (Prattica di musica, fols. 131r-132r), Thomas Morley (Plaine and Easie Introduction, *2r), and Giovanni Battista Rossi (Organo de cantori, 51) offered similar tabular representations of the mensural system, all clearly acknowledging their debt to earlier writers. Berardi (Documenti armonici, 170-72) acknowledged his sources much less clearly, even though he had simply combined textual and graphic elements from Zacconi and Rossi. Moreover, rather than probing mensural questions to the extent of his sources, he instead embarked on a Marian meditation through an allegorical reading of musical symbols, borrowing here from a sermon by Antonio Glielmo (Le grandezze della Santissima Trinità, 681-82), which he cited clearly. 
in the gentlemanly world of the Italian academies. The academies cultivated a style appropriate to their social milieu-overwhelmingly "aristocratic, Latinate, erudite, and male," in the words of Peter Miller. ${ }^{92}$ (Despite its being called an "academy," Bologna's Accademia Filarmonica was something of an exception to this general rule, its membership and concerns representing something rather more guild-like. $)^{93}$ Berardi borrowed from leading writers on the contemporary academic scene. He lifted his language for love and friendship (and for his touching eulogies of Scacchi) from Emanuele Tesauro, whose work practically constitutes a literary and intellectual encyclopedia for the academies. ${ }^{94}$ Earlier, in the Discorsi, Berardi had drawn from the writings of Venice's Accademia degli Incogniti (The Unknown Ones), in particular the Bizzarrie academiche (1638) of the academy's founder, Giovan Francesco Loredano. Loredano asked whether the beloved's tears or her song were more apt to bewitch the lover. In two discourses supplemented with musical performances he resolved the question in music's favor, even adducing ecclesiastic proofs to support his conclusion. "The church," he wrote, "[God's] beloved spouse, makes priests not to shed tears but to pour out song!" 95 Given the erotic context and potentially blasphemous content, it was a curious choice for a churchman such as Berardi. Ellen Rosand and Wendy Heller, who demonstrate Loredano's significance for Venetian opera, also show an awareness of his rhetorical extravagances. ${ }^{96}$ Yet it was precisely this, Loredano's seicentismo, that attracted Berardi, since the high-flown talk of friendship and love, about which Scacchi's works were silent, opened onto the social world of the academy. With careful pruning and the addition of the poem "Musica Dei donum" (Music, gift of God), Berardi simultaneously harnessed Loredano's rhetorical energy and curbed his libertine tendencies.

Consideration of the performative aspect of the Discorsi, moreover, suggests instances in which the term "plagiarism" would misrepresent Berardi's technique entirely. The Discorsi were initially written for live (possibly multimedia) delivery before an academy, ${ }^{97}$ and Berardi may have hoped that listeners

\section{Miller, Peiresc's Europe, 46.}

93. Musicologists have rightly devoted attention to a small group of institutions that avidly cultivated music. Yet such academies were exceptions in the broader world of Italian academies; see, for instance, data cited in Quondam, "L'Accademia," 858-81. In addition to Miller and Quondam, Mario Biagioli's Galileo, Courtier shows that issues of class and rank permeated the intellectual life of the academies; that this placed musicians at a disadvantage is confirmed in the studies of Dell'Antonio (Listening as Spiritual Practice) and Freitas (Portrait of a Castrato).

94. Tesauro, La filosofia morale, 504.

95. Loredano, Bizzarrie academiche, 200 (and, with slight changes, Berardi, Discorsi 1670b, 7): "E però la Chiesa amata sua Sposa, non fà, che i Sacerdoti versino lagrime, ma spendino il Canto."

96. Rosand, Opera in Seventeenth-Century Venice, 37-38; Heller, Emblems of Eloquence, 53.

97. Thomas Christensen has encouraged scholars to "rethink the central role we accord the text in our histories of music theory": Christensen, "Fragile Texts, Hidden Theory," 182. In the 
would recognize passages drawn from the Incogniti and from Zarlino. By invoking "the most learned Zarlino" he prepared them to do so. Anything more explicit, Ann Blair observes, "risked insulting educated readers, depriving them of the pleasure of recognizing the allusion." ${ }^{98}$ Zarlino, to a greater extent than any other sixteenth-century musical author, attained wide auctoritas, his very name bespoke an intellectual solidity that commanded respect and deference. For the Discorsi Berardi wisely drew above all from Zarlino, who remained the touchstone for learned musical discourse in the seventeenth century. The Discorsi also illustrate why the extent of Zarlino's presence in seventeenth-century writings has never been fully recognized: writers drew from him without citation, and - especially beyond the world of professional music making - favored literary and speculative passages from the first book of his $I s$ titutioni barmoniche, which today tend to be less well known than the rest of the treatise.

In every respect Berardi demonstrated good knowledge of academic culture, especially that of Rome and Bologna. In 1671 the Accademia de' Gelati (The Frigid Ones) of Bologna printed musical discourses by two of its members, Girolamo Desideri ("The Indifferent") and Giovanni Battista Sanuti Pellicani ("The Fearful”). Jurists and scholars by profession, they participated in Bologna's musical culture as writers, composing discourses and oratorio librettos. ${ }^{99}$ Desideri's lengthy oration "Della musica" took up subjects now familiar from Berardi's Discorsi: a defense of music against its critics, praise of its nobility and virtue, an investigation into its inventors, its effects upon humankind, and its presence among animals. Pellicani's discourse upon augmented and diminished forms of perfect intervals would seem altogether too technical for a literary academy. He adapted it to the audience by borrowing the same "humanistic" passages from Zarlino that are

case of the Discorsi Berardi may well have given a multimedia performance, featuring not only music and spoken prose but also many of the devices beloved of academies-acrostic, epigram, emblem, and motto. To close the second discourse Berardi borrowed from Cerone a spiritual acrostic on the hexachord, at the same time designing a visual emblem of the hexachord with a Latin motto. This emblem first appeared on the cover of his Sinfonie a violino solo (1670), which itself features epigrams that channel the music toward polite conversation.

98. Blair, Too Much to Know, 243. The same might possibly be said of Berardi's subsequent borrowings from Tesauro and Francis Bacon (compare Bacon, Sapienza degli antichi, 240-46, with Berardi, Arcani musicali, 29-30).

99. Pellicani and Desideri wrote oratorio librettos for Bolognese composers including Colonna and Cazzati; see Crowther, Oratorio in Bologna, 144-46. Desideri was almost certainly the "anonymous author styling himself 'L'indifferente" "who wrote the libretto for Colonna's La morte di S. Antonio di Padova (1676), which was performed for the Gelati (ibid., 67-68). Pellicani received the dedication of Cazzati's Sonate a due istromenti, op. 55 (1670), and published a cantata of his own (for which he also wrote the text) in the collection Melpomene coronata da Felsina (1685). Here, the compositions of two social "illustrissimi" (Pellicani and Count Pirro Albergati) precede those of professional musicians. 
found in Berardi's Discorsi. These established the link between musical mathematics and their effect on virtuous human action. ${ }^{100}$

Heightened rhetoric and high-minded subjects befitted academic audiences, as we see in a contemporaneous set of Roman musical orations, Vincenzo Chiavelloni's Discorsi della musica (1668). Chiavelloni explained that music shared with an academy the goal of tuning souls to virtue. And these were no ordinary souls. Chiavelloni wrote his Discorsi for the aristocratic Accademia degli Sterili (The Sterile Ones) and dedicated them to Cardinal Giacomo Rospigliosi, nephew of the new pope, Clement IX. Clement had been the most distinguished librettist of Barberini Rome, and his nephew followed suit. (I suspect that the premiere of their opera La comica del cielo prompted Chiavelloni to publish his Discorsi. $)^{101}$ The Discorsi have received little attention from scholars, doubtless because, in over five hundred pages, Chiavelloni never once deigned to address music in "relevant" detail. From this George Buelow reasonably concludes, "it seems likely that he was not a musician." 102 Yet the same conclusion might be inferred for Berardi on the basis of his Discorsi, or, as we shall see, for Agostino Steffani on the basis of his Quanta certezza habbia da suoi principii la musica (1695). The qualities that now make Chiavelloni's Discorsi so eminently forgettable were the very ones that musicians such as Berardi and Steffani sought to emulate. Chiavelloni's work depended upon central (neo-)Platonic binaries: form and image, truth and appearance, soul and body. Because the physical lay far from ideal forms, the sense of hearing perceived only images of true objects. Sounding music as "found in the sensible harmony of voices" therefore offered only "momentary beauty," since it bore a "mere resemblance" to true Beauty. Nevertheless, as "simulacra" and "mirrors" of true objects, musical sounds might stimulate "very deep thoughts and curious contemplations": thus, "dispatched quickly by the pleasing harmony of various voices [one] will fly with the understanding to that most sweet and perfect melody that the choir of virtues sounds within human souls."103 To focus upon sounding music would confuse a means with the end. Chiavelloni's Discorsi guide a

100. Compare Zarlino, Le istitutioni harmoniche, bk. 1, ch. 2, 4-7; Pellicani, "De gl'intervalli musicali," 133-35; and Berardi, Discorsi 1670b, 4-6, 10.

101. Chiavelloni's Discorsi were commissioned by Bernardino Rocci, leader of the Sterili, who was made a bishop by Clement in 1668. That same year Rome witnessed the premiere of La comica del cielo, with music by Antonio Abbatini and staging by Gian Lorenzo Bernini. Although Clement was widely credited as librettist, Davide Daolmi has recently argued that the primary author was actually Giacomo: Daolmi, "Sulla paternità." On Rocci's musical activities with Kircher, see note 153 below.

102. Buelow, "Chiavelloni, Vincenzo."

103. Chiavelloni, Discorsi della musica, 23-36: "[la] momentanea bellezza, quale ritrovasi nell'armonia sensibile delle voci" (35); "una mera somiglianza" (24); "ò simolacri, ne i specchi; dopo varii sottilissimi pensamenti, e curiosissime contemplationi” (27); and ibid., 42-43: "dall'armonia dilettevole di varie voci ispedito, e veloce, volarà coll'intendimento à quella soavissima melodia, che negl'animi humani concerta il Choro delle Virtù, \& è la perfetta.” 
gentleman safely past the moral dangers posed by singers' voices, and lead him to the virtuous consumption of the Rospigliosis' sumptuous operatic spectacle. ${ }^{104}$ Whether or not Chiavelloni was a musician-or even an original writer-his social and philosophical attitudes were widely shared and imitated. They merit closer inspection.

\section{Musical Knowledge}

"Sterile," "frigid," "bizarre," "unknown": the self-effacing epithets adopted by academies and academicians might equally characterize a current view of their musical discussions. Yet seventeenth-century musicians had good reason to imitate them, especially when they avoided practice and practical prose. ${ }^{105}$ The wide currency of Platonic ideals of music and friendship had been prepared by centuries of speculative theory that employed musical mathematics to uncover universal realities. That tradition, as "sounding number," is often accorded the solidity of doctrine. Here, however, I emphasize the tension between physical sound and abstract number, and the variety of negotiations and compromises it generated. Writers might incline toward one or the other in defining music's essence and the nature of true musical knowledge. Each solution posed broad disciplinary consequences, from the professional to the epistemological. Berardi did not merely adopt the pose or tone of an academic gentleman; he explicitly engaged the epistemological questions that typified scholarly writing. Many musicians did so. That they should appropriate intellectual discourse is utterly unsurprising. The question, rather, is why they appropriated intellectual discourses that perpetuated Boethian prejudices against practicing musicians. The answer lies not so much in the "content" of these music-theoretical writings as in the cultural and social prestige of the writers.

Musical learning was rooted in early modern mathematical culture, itself then undergoing fundamental epistemological and professional change. As Marcus Hellyer explains, mathematics had traditionally been granted limited explanatory powers: it could not produce true "knowledge" (scientia). Metaphysics and physics, qualitative rather than quantitative, were considered the only disciplines capable of producing true demonstrative knowledge,

104. Ibid., discourses $5-8$.

105. The interlocutors in jurist Grazioso Uberti's Contrasto musico (1630) sought a via media for discussing music in polite company, one that sounded neither too musicianly nor too pedantic: Uberti, Contrasto musico, 141-52. As Dell'Antonio observes, it "reads like a guide to discourse about music for the aspiring virtuoso of taste, providing . . learned exempla so that the reader may learn how to elegantly hold either side of a sophisticated discussion on music": Dell'Antonio, Listening as Spiritual Practice, 62. Many of Uberti's exempla also appear in Berardi's writings. 
which "proceeded from indubitable propositions through syllogism."106 Mathematics was a technical or "mechanical" field. Its lower truth-status manifested itself in the professional lives of mathematicians: they attained lower social and institutional status and were paid far lower salaries. ${ }^{107}$ In the late sixteenth century Christoph Clavius led mathematicians in arguing that theirs was indeed a science, capable of "true causal demonstrations." 108 This highest standard of certainty extended only to the two branches of pure mathematics, arithmetic and geometry, but not to mixed mathematics such as music. Arithmetic and geometry, Clavius explained, were "far superior" to all others (including music) because they considered quantity in the abstract. Music, like other forms of mixed mathematics, considered number as concretized in some substance and perceived by the senses. ${ }^{109}$ A musical composition might well manifest or exemplify the effects of a distant mathematical cause. Considered ontologically, however, that same composition was too far removed from the cause to be scientifically demonstrative: it was too physical, too particular, too embodied. ${ }^{110}$ In time, Clavius's students and heirs expanded the category of the musically demonstrative. Kircher, for instance, described the results of acoustical experiments as "demonstrative."111 Galileo pushed further still the validity of mathematical claims regarding the physical world (especially those involving observation, experiment, and instruments). Reformulating and extending mathematics according to established canons of knowledge benefitted the discipline and its practitioners. Galileo's career as mathematician, as Mario Biagioli shows in Galileo, Courtier, was

106. See Hellyer, Catholic Physics, 78-79.

107. Biagioli finds that sixteenth-century university mathematics teachers received "between one-sixth and one-eighth the salary of philosophers" and as little as "one-tenth [that] of physicians or jurists": Biagioli, Galileo, Courtier, 7, and "Social Status," 53.

108. See Hellyer, Catholic Physics, 120. On the relationship of epistemology to mathematicians' professional status (with specific reference to Clavius), see also Dear, Mersenne, chs. 3-4, and Discipline and Experience, chs. 2 and 6; and Biagioli, "Social Status" and Galileo, Courtier, ch. 1 .

109. Clavius, Euclidis elementorum, Prolegomena ("Disciplinarum mathematicarum divisio"): "statuunt duas longe primas, praecipuasque scientias, Arithmeticam, \& Geometriam."

110. The low status of musical compositions within this epistemological hierarchy accounts for the low and somewhat informal status of the musical "work-concept." The gradual weakening of these ideas therefore abetted the emergence of a werktreue musical culture, the subject of Lydia Goehr's classic monograph The Imaginary Museum of Musical Works. The importance of demonstrative knowledge emerges even in writings that problematize it. For instance, Liberati proclaimed that music was "mere opinion," incapable of yielding "any certainty whatsoever": Liberati, Lettera, esp. 12-18 ("una mera opinione, di cui non si può dar certezza veruna"). He argued that music was, like all sciences, a posteriori and could not be known directly from causes but only indirectly, through physical effects as observed by the unreliable senses. Thus, the superiority of demonstrative knowledge doomed music-theoretical certainty.

111. Clavius's student Giuseppe Biancani considered the discipline of music to be demonstrative, and thus to have achieved the status of a real Aristotelian science. Kircher at times claimed to follow Biancani. See Biancani, De mathematicarum natura dissertatio, 31; Kircher, Musurgia universalis, 1:46-47; and Bianchi, "Prodigious Sounds," 153-57, 171-80. 
shaped by new professional possibilities and pitfalls in a shifting epistemological landscape.

Nevertheless, Galileo's more far-reaching claims did not meet with immediate and universal acceptance. Even had they done so, musicians would have reaped few perceptible benefits, at least in the short term. ${ }^{112}$ Music was mathematics, but musicians were not mathematicians. Deep ambivalence persisted over the role of physical sound and sense perception in musical knowledge. Musicologists have understandably taken an unsympathetic view of this sort of material. Take the case of Artusi, who worried that "sensuous excess" could "deceive" and "corrupt" the sense of hearing. ${ }^{113}$ The Artusi-Monteverdi debate was well known to Scacchi and shaped his understanding of the art he professed. Like Monteverdi, Scacchi advocated exceptions to traditional harmonic and contrapuntal practice, citing Plato's dictum that words are the mistress of the harmony. ${ }^{114}$ In rebutting Artusi, however, Scacchi offered a starker renegotiation of theory and practice, reason and sense. Monteverdi had argued that aspects of prima and seconda prattica had long been valid stylistic choices. Scacchi, by contrast, claimed that earlier composers had possessed just a single style for setting both Latin liturgical texts and light vernacular texts. Where Monteverdi spoke of a seconda prattica, Scacchi spoke of a prattica moderna. ${ }^{115}$ Moreover, in the "Raggionamenti" Scacchi argued that the moderns had achieved stylistic diversity (proof of their superiority) only by placing sense before reason and practice before theory. In defending musicians' embodied judgment, he explicitly rejected a polite liberal arts education (upon which Artusi's writings rested) as the foundation for musical knowledge and auctoritas:

It was not permitted [in the past] to take the title of master of harmonic art if one had not previously studied arithmetic, geometry ... as well as being versed in grammar, meter, dialectic, rhetoric, philosophy, and also history.... [Later] they learned that some studies were not quite appropriate for practice, but only for speculative [music] and theory. Therefore, I say that music was rediscovered for pleasure, because the sense must be pleased and refreshed with song-but not with the discourses of honorable theorists. And even if the first elements and

112. Rebecca Cypess has recently argued, however, that the increasing validity granted to knowledge produced by scientific instruments and experimentation was not unrelated to contemporary experimentation with musical instruments and thus to the development of distinct instrumental styles: Cypess, Curious and Modern Inventions. I thank her for allowing me to consult the proofs of her book prior to publication.

113. Artusi, L'Artusi, fols. 10v-12r, 40r-43r, here 4lv: "lo Eccellente sensibile corrompe il senso"; and 42r: "il senso è ingannato"; Artusi cites Clavius's writings at folio 47r.

114. Scacchi, Cribrum musicum ad triticum siferticum, 132-33, "Raggionamenti," fol. 22r, and Breve discorso, fol. 12r-v.

115. Scacchi, "Raggionamenti," fols. 21v-22r, discussing (inter alia) Vingt et six chansons musicales or nouvelles a cincq parties (Antwerp: Susato, [1543]; RISM $1543^{15}$ ) and Le treziesme livre contenant vingt et deux chansons nouvelles a six et a buyt parties (Antwerp: Susato, 1550; RISM $1550^{14}$ ). Scacchi articulated a more nuanced view in the Breve discorso (fol. 14r). 
rules were taken from the speculative musicians who were our first masters, nevertheless many things of which theory approves current practice shuns, and vice versa. For the ear has been, and [always] will be, the true master of music in bringing it to an exquisite harmonic perfection. And it is true that music was invented to delight . . . as all philosophers agree. ${ }^{116}$

Clearly, Scacchi's “philosophical consensus" was more assertion than fact. Yet such appeals to the dignity of musicianly knowledge won scholarly sympathy in the relatively populist twentieth century. Thus, we remember Artusi as a petty conservative and sophist, impotent in the face of Monteverdi's challenge to settle their dispute by a demonstration of compositional skill. This vision of Artusi is depicted with exceptional clarity and force by Gary Tomlinson: an Artusi whose "reasoning . . . reveals the limitations of much late scholastic thought"; who "retreated adroitly behind a display of degenerate scholastic logic"; who "responded with a sophistic barrage of semantic hairsplitting, which [reduces] to a self-serving and empty syllogism"; who "adroitly ... ignored the testimony of his ears"; who argued "disingenuously" from "hollow" premises only to end in "self-contradiction."117 Monteverdi's challenge to a compositional duel, though rhetorically effective, ignored music's ontological embarrassment. On the fundamental question of music's disciplinary identity, erudite opinion would have been on Artusi's side. ${ }^{118}$ And even musicians-Scacchi among them-hewed to Artusi more than is generally suspected. ${ }^{119}$

116. Scacchi, "Raggionamenti," fol. 21r: "e benche non fusse lecito in quel tempo usurparsi il nome de Maestro nell'arte Armonica, se prima non haveva studiato l'Arithmetica, la Geometria ... oltre l'essere versato nella Grammatica, Metrica, Dialectica, Rhetorica, Philosophia, et anco nell'istorie . . poiche hanno conosciuto, che alcuni studii non erano punto à preposito per la Prattica; mà si bene per la speculativa, et la Theorica; onde dico, che la Musica è stata ritrovata per dilettare, perche il senso deve essere lusingato, et ricreato con il canto, e non altrimente con li discorsi delli honorati Teorici; e benche i primi elementi, et Regole l'habbiano rice[v]uti dalli speculativi, di questa nostra Professione, i quali sono stati i primi nostri Maëstri, niente di meno, molte cose, al presente, ch'approva la Theorica, l'atto prattico l'abborrisce, et vice versa; perche l'orecchia è stata la vera maestra della Musica, et sarà per l'avenire, per ridurla ad un' esquisita perfettione circa l'Armonia; e che sia il vero che la Musica è stata inventata per dilettare . . conforme dicono tutti i Philosophi." In the Declaratio (fol. 18r/Br) Scacchi suggested a distinction between the "simple theorist, who has no understanding of practical matters," and the theorist who, "both theorist and practitioner, attains the highest perfection" ("Potest esse Theoricus simplex, qui nullam habet c[o]gnitionem de his, quae ad Practicam spectant. Alii etiam nominantur Theorici [\&] Practici simul, qui ad summam nempe pervenerunt perfectionem"). Artusi, it must be noted, rated practitioners more highly still at times: see, for example, Artusi, L'Artusi, fol. 34r.

117. Tomlinson, Monteverdi, 23-27.

118. In the seventeenth century "erudite" tended to indicate antiquarian and linguistic (rather than technical) learning, and suggested a high level of educational and social formation. See, for instance, Stolzenberg on Kircher (Egyptian Oedipus, 20-21) and Miller on Peiresc (Peiresc's Europe).

119. For Scacchi, surprisingly, Artusi was an authority (and unacknowledged source) who exerted a remarkable influence upon his writings and music. For a detailed examination of 
Abstract disciplinary considerations, moreover, shaped musicians' dayto-day existence, since epistemological rifts opened along fault lines of class and rank rather than those of creative excellence. Much of the writing we are examining could be classified as lying within a broad speculative "genre" or "tradition" of "music theory." 120 Yet such classifications, accurate with respect to content, say little about the cultural conditions that made the tradition attractive in the first place. Musical erudition was dominated by writers who were aristocrats, high ecclesiastical and political officials, and prominent intellectuals first, and only then "music theorists." Three such luminaries from Berardi's world, Caramuel, Kircher, and Giovanni Battista Doni, demonstrate this confluence of musical thought and social attitudes.

Caramuel, a nobleman and bishop, was among the era's great polymaths; he discussed music frequently in treatises on mathematics, theology, and linguistics. According to Caramuel, a true musician might lack any discernible musical ability. He claimed to have it on good authority that Mersenne-“a most insightful and most ingenious musicus" - could not even sing. ${ }^{121} \mathrm{On}$ the other hand, "all those who are showered with acclamation and great applause and supported with a large salary are not musici: for generally they make music with a chance reliance (guided by nature) upon ear and voice, and do not know [ sciunt] why or how they sing or observe rests."122 $\mathrm{He}$ lamented that composer Giovanni Valentini "thought I was speaking Arabic when I discussed the varieties and sizes of intervals with the emperor [Ferdinand III]." 123 Caramuel viewed such ignorance as tantamount to a "disease," one that "infected" other mathematical sciences wherever they

Scacchi's indebtedness to Artusi, see Patalas, "Music Theory"; for a musician who sustained Artusi's position in the Monteverdi controversy, see Tevo, Il musico testore, 175-79.

120. For two excellent surveys of music-theoretical literature, see Blasius, "Mapping the Terrain," and Christensen, "Genres of Music Theory." I view our analyses as complementary rather than contradictory. Here, however, I take greater interest in "talk about music" (that includes "music theory" but is not defined by it), and in social considerations within the broader context of seventeenth-century erudition (rather than the importance of music-theoretical literature for traditional music-scholarly concerns).

121. Caramuel y Lobkowitz, "Musica," bk. 1, art. 11: "Aliqui, qui nesciunt canere, et tametsi aure obtusâ sint praediti . . sunt boni Musici. . . . Ut demonstrem secundam P. Marci Marini Mersenni meminero, quam fuisse accuratissimum et ingeniosissimum Musicum . . . quem tamen canere non scivisse, eius solii et amici testantur." (The first sentence quoted here is underlined in the source.) Caramuel's "Musica" remained incomplete at his death in 1682 and bears dates ranging from the 1640s to 1669. For a précis, see Golub, "Juraj Križanić's "Asserta Musicalia," and Sabaino, "Musica universalis, universus musicalis"; these two authors independently rediscovered different parts of the manuscript at different times.

122. Caramuel y Lobkowitz, "Musica," bk. 8, note 1: "et hos omnes, qui magno accursu et applausu auscultantur, et magno stipendio foventur, non esse Musicos: plerique enim omnes auris et vocis felicitate freti, naturae ductu . . . modulantur; et quidquid et cur aut sileant aut canant non sciunt."

123. Ibid., bk. 1, art. 11: "Et hic ipse putabat me Arabice loqui, cùm de diastematum mensuris et differentiis cum Imperatore . . . disserebam." 
fell into practitioners' hands - sailors ignorant of trigonometry, bricklayers who styled themselves "architects," painters who could hardly render a flat surface. ${ }^{124}$ Caramuel's attacks amounted to more than just invidious social distinctions; as Daniele Sabaino astutely observes, they arose from his preoccupation with "the deep unity of knowledge" that only "metaphysical certainties" guaranteed. ${ }^{125}$ Doni, a Florentine patrician who served as secretary to the College of Cardinals under the Barberini, had probably studied with Clavius. He admired Boethius as much for his musical science as for his patrician attitude toward social and musical inferiors. He infamously observed that Frescobaldi's "knowledge [science] lies in his finger tips."126 "Science" can only be taken ironically here: for Doni, as for Caramuel, knowledge (scientia) resulted from intellection. No "carnal musicology" for these two!

Kircher, an intellectual acquaintance of both Caramuel and Doni, was even more important for Berardi and his contemporaries. The very structure of Kircher's Musurgia reflected a Boethian epistemological hierarchy, in which practical music making was a stepping stone on the long ascent to musica mundana. Although the Musurgia is mostly remembered for its positive and detailed portrait of seventeenth-century Roman music, seventeenth-century Roman musicians responded with "indignation and irritation."127 And with good reason. ${ }^{128}$ Among other provocations, Kircher launched a preemptive strike against musicians who would question his musical auctoritas on the grounds that

I am not a schoolmaster teaching boys the ABCs, because I am not a choirmaster, because I have not published my compositions for money. . . . They do not know that this conclusion is of the very worst sort and logically ridiculous. "He does not profess the art (I speak of earning a living [from it]), therefore he does not understand it." . . . The Prince of Venosa did not profess music, therefore be did not understand it? The renowned kings Ptolemy and Alfonso did not profess music and astronomy, therefore they

124. Ibid.: "Nec sola Musica synthetico morbo laborat; nam haec luas se propagat, et alias scientias excellentes infecit. Unam aut alteram proponam, quae à Viris indoctis tractantur."

125. Sabaino, "Musica universalis, universus musicalis," 328: "[la] profonda unità dello scibile" and "certezze metafisiche."

126. Doni, letter to Mersenne of July 22, 1640, in Mersenne, Correspondance, 11:488: “on peut dire qu'il ait toute sa science aux bouts des doits." On the confluence of Doni's social and musical ideas, see Bianchi, "Bad Latin, Bad Manners."

127. See Johannes Schega, letter to Kircher of June 17, 1650, in Kircher, Correspondence, I-Rpug 561, fol. 164r: "Quod attinet ad Romanos Musicos, quibus indignationem et stomachum movere videtur opus Musurgicum."

128. Kircher mocked musicians broadly (Musurgia universalis, 1:560-64), and claimed (twice!) to have written music that even Rome's best musicians were not up to the task of performing (ibid., 1:561, 2:326). Moreover, his system of combinatory composition (see pages 106-7 below) struck even more deeply at musicians' claims to professional dignity. 
did not understand it? [This] conclusion by ignorant musicians is, as I have said, of the very worst sort. ${ }^{129}$

Unlike Caramuel and Doni, Kircher was not himself a noble, but he enjoyed special success - even among Jesuits - in edifying noblemen and turning them into patrons. As for Rome's disgruntled musicians, a Jesuit confrère offered astute counsel: "Your Reverence ought to pay them no mind, since you are so much more prominent than they and beyond the reach of envy." 130 Whatever we think of their social attitudes, the hard fact is that Caramuel, Doni, and Kircher enjoyed a level of social and intellectual prestige unattained and unattainable by Berardi and Scacchi; only the former were accorded wide auctoritas, not the latter. Berardi recognized this social reality early on. In dedicating his Discorsi musicali to Pietro Boninsegni he remarked, "I have been honored by your kindness to give discourses at the most noble academies in your house, notwithstanding the slightness of my merits and the different profession that I exercise as maestro di cappella."131 Seventeenth-century convention demanded that a dedicator profess his unworth; it is nevertheless significant that Berardi claimed to be unworthy precisely because he was a professional musician.

The treatise that followed the Discorsi, Berardi's Ragionamenti musicali (1681), frequently addressed musical epistemology and even devoted an appendix (the Aggiunta . . . alli suoi Ragionamenti musicali) to proving "that music is not an art, but a true and real science." Art treats mere "makeables," the external products of manual labor; science, by contrast, treats "certain," "evident," "infallible," "perfect" knowledge of "eternal" things. ${ }^{132}$ Thus far, a decent imitation of Clavius. But what interest could Berardi have had in proving it? And how to reconcile it with his profession? The intellect must

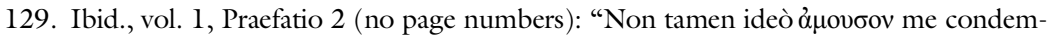
nabunt, quod Ludimagister Alphabetaria elementa pueris non tradiderim, quod publicum in Ecclesiis Choragum non egerim, quod in compositionibus alicuius lucri causa mercenarium me non exhibuerim. ... [N]esciunt, pessimam hanc illationem esse, \& in Logica ridiculam. Artem non professus est, ergò eam nescit (loquor semper de ea, cuius subsidio quisque vitam tolerat, professione). Princeps Venusinus Musicam non professus est, ergò eam nescit? Ptolomaeus, \& Alphonsus Reges clarissimi, Musica $m$ \& Astronomia $m$ no $n$ professi sunt, ergò eam nescierunt, pessima sanè, ut dixi, illatio est Musicorum imperitoru $m . "$

130. Johannes Schega, letter to Kircher of June 17, 1650, in Kircher, Correspondence, I-Rpug 561, fol. 164r: "Non debet [Romanos Musicos] Reverentia Vestra curare, cùm nimis emineat eorum comparatione, sitque extra invidiam omnium."

131. Berardi, Discorsi 1670a, 3: "Nelle nobilissime Academie ragunate nella sua Casa, senza riguardo del mio poco merito, e della professione diversa ch'essercito di Maestro di Cappella sono stato honorato dalla sua gentilezza di fare discorsi."

132. Berardi, Aggiunta, 7: "Nel quale si pruova, che la Musica non è Arte, mà Scienza vera, e reale"; and 22-26: "cose fattibili"; "certa, \& evidente per mezo del discorso d'una cosa infallibile, \& in questa parte è perfetta"; "principii . . . eterni." I suspect Berardi to be responsible for a significant alteration to the Casanatense copy of Scacchi's Cantilena ("Ad Studiosum Lectorem"): "In Arte ${ }^{\text {scientia }}$ Musica." 
guide practice, he argued, even though it was not necessary for speculative music to seek fulfillment through action. Nevertheless, music could not reach true perfection without the complete union of theory and practice. By comparison with Scacchi, Berardi inclined more toward the former than the latter; yet he can hardly be said to have resolved the tension between the two. As important as music's position among quadrivial sciences was the quadrivium's place among the liberal arts, which "make a man free by allowing him to keep far from vulgar earning and from every illicit pleasure." 133 These words issue from Berardi's stand-in Felice, who wanders the countryside discoursing precisely because he finds himself "free from the occupations of the chapel." On the title page of the Ragionamenti Berardi styled himself first "professore armonico" and only then "maestro di cappella." His wobbly epistemological argument, bolstered by Aristotle and Aquinas, supports an altogether more practical line of reasoning. Music is a science because its object is not physical; this qualifies music as a liberal art; and that, in turn, qualifies its practitioners as noble. (Hence the list, in the Ragionamenti, of noblemen-musicians from King David to João IV of Portugal.) Whatever "professore armonico" actually meant, it was more aspiration than reality for Berardi. ${ }^{135}$

Given Scacchi's aversion to this kind of talk, Berardi's fixation upon musical science also had something of the oedipal about it. "One must apply himself to this science," opines Giuseppe in the Ragionamenti, "not to delight the hearing (as some have thought), since that does not engage virtuous action, as it is for mechanical and vulgar men to satisfy the sense only."136 If these words sound familiar, it is because they are Scacchi's - now turned against Scacchi's position. ${ }^{137}$ That Berardi's and Scacchi's treatises share a title only heightens the irony.

\section{Striking a Pose: Berardi's Contemporaries and the Written Word}

If Berardi's appropriation of Scacchi defies complete explication, it is just as well. For beyond the idiosyncrasies of his particular case lies a broader

133. Berardi, Ragionamenti musicali, 17-22: "rendono l'huomo libero, con tenerlo lontano dal vil guadagno, e da ogni piacere illecito." Here, he distinguishes the liberal from the mechanical arts. On the liberal and mechanical arts generally, see Whitney, "Paradise Restored"; for similar distinctions made by "persone eccellenti" in medicine and the visual arts, see Ago, Tanti modi per promuoversi, 4-7, 201-4; for such a distinction in contemporaneous musical writings, see Ouvrard, "La musique rétablie," F-TOm 822, 22-24/fols. 24v-26r.

134. Berardi, Ragionamenti musicali, 15-16: "liberi dall'occupationi della Cappella." As noted, the Felice of the dialog is Berardi; "Giuseppe" is Giuseppe Orsolini, a bass at the cathedral of Spoleto who apparently sponsored the Ragionamenti and dedicated them to Carlo Antonio Sampieri.

135. Ibid., 76-81; on Berardi's professional travails, see note 82 above.

136. Ibid., 97: "Si deve dar opera à questa Scienza, non per dilettare l'udito, come hanno pensato alcuni, poiche in questa parte non riguarda all'atto virtuoso, essendo cosa da huomini mecanici, e volgari soddisfare semplicemente al senso."

137. Scacchi's statement is quoted on pages 96-97 above. 
phenomenon of musicians' professional and social self-presentation. Every means and motivation glimpsed in Berardi's writing is easily traced in that of his contemporaries: the technique of literary borrowing and the sources borrowed from; the careful emulation of academies and erudites; the channeling of epistemological ideas toward the construction of a persona. Berardi's importance, therefore, is less as an individual than as a representative figure. He illuminates the conditions and ambitions of a social and professional group, as we shall now see through contemporaries who engaged music as composers, performers, and-crucially—writers. From a common musicological point of view they are backbenchers, second-stringers, Kleinmeister. From another, these Berardi-like personalities were once the lifeblood of a musical culture.

We begin with Antonio Abbatini, a Roman composer and maestro di cappella whom Berardi praised as a "most learned theorist" and "luminary of the music of our time." 138 Abbatini, keenly aware of his social and financial disadvantages, carefully cultivated an intellectual persona. He served as Kircher's musical advisor for the Musurgia and hosted a series of academies for distinguished literati and musicians at his home. ${ }^{139}$ (Berardi may well have attended.) There, he cast musical mathematics in affective language that befitted his audience. For a 1668 oration he imagined Zarlino's senario as "the most hidden secrets of this most noble science of music," which God himself "sealed in boxes of numbers." Reaching into the boxes, Abbatini produced intervals the way a magician pulls rabbits from a hat:

Now then, let us see what great treasure is sealed up in ... this box of numbers. ... Open it! It isn't possible? Use your wits! You [still] can't open it? . . Oh, what a beautiful sound! .. . Oh, marvel of the world! . . Oh, what a prodigious thing! Quickly, there is no time to lose! ... Oh, what a sweet sound! ... Onward, onward to greater prodigies! ... Oh, what a lovely sound, what lovely harmony! Listen, listen! . . Oh, wonderful secret! . . O Oh, what sweetness! . . Oh, miracle of nature! . . . I am beside myself with shock! . . . Are you not amazed? ${ }^{140}$

138. Berardi, Ragionamenti musicali, 135: "dottissimo Teorico"; Berardi, Il perché musicale, 23: "i due lumi della Musica del nostro Secolo . . l'Abbatini, \& il Liberati." Abbatini's autobiographical poem is transcribed in Ciliberti, Antonio Maria Abbatini, 426-33.

139. These included Kircher, Matteo Orlandi (prior general of the Carmelite Order and author of a Directorium chori, 1668), and Arcangelo Spagna (author of Oratorii overo melodrammi sacri, 1706), as well as high-placed Roman musicians including Lelio Colista and Domenico Dal Pane. Abbatini also invited the poet Sebastiano Baldini-who never came.

140. Abbatini, Le lezioni accademiche, 447-48: "L'haver l'onnipotente mano racchiuso dentro scatolini di numero, i secreti più occulti della nobilissima scienza della musica. . . . [H] ora vediamo che gran tesoro stà rinchiuso dentro à . . . questo scatolino di numeri. . . . Apritelo; non è possibile. Ingegnatevi. Non lo potete aprire? ... O' che bel suono. ... O' meraviglia del mondo. ... Oh che cosa prodigiosa presto non si perda tempo. ... O' che dolce suono. ... Avvanti avvanti à vedere maggiori prodigii. . . . O ' che vago suono, ò che vaga Armonia. Sentite, sentite! . . O mirabil segreto. . . . O' che dolcezza. ... O' miracolo della Natura. . . Resto fuori di me per lo 
Exhortation and ejaculation climaxed with the revelation that the year 1668 was itself senary, a conceit that spilled over into the succeeding oration. Abbatini enlivened a potentially pedantic subject with a rhetoric of rapture, distancing it from the commonplace by connecting it to profound mysteries.

Other musicians diversified their professional profiles, modeling themselves upon the era's polymaths. Giovanni Andrea Angelini Bontempi enjoyed a distinguished musical career, as castrato, composer, and author of the Historia musica (1695). Yet in letters to the composer Teofilo Macchetti, then at work on his learned treatise "Curiosità musicali," Bontempi instead touted his privileged relationship with Johann Georg II of Saxony, his several country estates, his indifference toward money, his preference for "nobility." $\mathrm{He}$ mentioned his historical writings, his position as engineer of theatrical machines, and his studies in various branches of applied mathematics: perspective, architecture, horology, and gem-cutting, all staples of the mathematical compendia produced for court mathematicians. ${ }^{141}$ Bontempi projected the image of court intellectual rather than mere musician both in his persona and in his musical theories. He explained that "Platonic" musical mathematics (which took reason as its object) differed so qualitatively from "Guidonian" counterpoint (which took the sense as its object) that "the one cannot be considered together with the other." Arithmetic established the laws of musical proportion; music, a mere "subaltern" discipline, could not "by any means overthrow this order with the sense."

It proved easier to (re)negotiate the relationship between theory and practice on paper, rendering a convincing literary performance all the more important. When musicians attempted to leave music behind for other realms they discovered that their old identity clung stubbornly to their new persona. Agostino Steffani began his career as a singer and ended it as a bishop, papal official (protonotario apostolico), and diplomat. As Colin Timms shows, the transition from the one to the other provoked consternation: "I [ find] this metamorphosis of an entertainer into a bishop," commented one observer, "just as ridiculous as the transformation . . . of a courtesan into a philosopher." "143 Sometimes the consternation is entirely ours, as in the case of castrato and composer Atto Melani, who retired from music to become a diplomat

stupore. . . . Non vi stupite?" Cf. Zarlino, Le istitutioni harmoniche, bk. 1, chs. 14-15, 23-26. See also Lezione no. 2 (Abbatini's "Lettione 4") in Abbatini, Le lezioni accademiche, 452, 454.

141. Bontempi, letters to Teofilo Macchetti of February 16 and June 23, 1696, in Bontempi, Alcune lettere, 4, 11-12. For a relevant example of a mathematical compendium, see the Cursus mathematicus of Kircher's student Gaspar Schott.

142. Bontempi, letter to Teofilo Macchetti of February 18, 1696, in Bontempi, Alcune lettere, 5-6: "L'Armonia di Platone ha per oggetto la ragione; quella di Guido, il senso. Cadono tra l'una e l'altra la divisione, e la differenza, ne l'una può entrare in consideratione unitamente con l'altra. . . . [L]a Musica non può col Senso in maniera alcuna sovvertir quest'ordine, come sottalternata.”

143. Neue und curieuse Relation von einem Reisenden (Flensberg, 1718), quoted in Timms, Polymath of the Baroque, 314. 
and protonotario apostolico. If Steffani's contemporaries viewed his musical past as contaminating his political and ecclesiastical ambitions, in Melani's case, as Roger Freitas shows, modern scholars have tended to view the latter as contaminating the former. Melani himself was of a different mind. "I have tried to get myself out of the rank of musico," he remarked in 1658, "and happily I have been able to do it." 144

Steffani had already risen to the rank of diplomat and protonotario apostolico by the time he published his Quanta certezza habbia da suoi principii la musica (What Great Certitude Music Draws from Its Principles, 1695). Written in response to a gentlemanly academic gathering, Quanta certezza treats the same subject as Berardi's Aggiunta: the priority of abstract, mathematical musical science. "In his secular compositions . . . ," Timms concludes, "Steffani was a modern, but in his writings he was unequivocally conservative." 145 Quanta certezza is indeed archaic, but not unusually so, since, as we have seen, explicating Pythagorean ratios à la Zarlino was also eminently contemporary. Even at this late date, Steffani may still have heard Zarlino's prose as balancing respectability and fashionability in a measure ideal for creating a favorable impression in the social circles to which he aspired. Like many writers and musicians, he did not limit himself to merely exploring Zarlinian topoi but borrowed Zarlino's very words. Steffani, however, articulated them with unusual force by larding them with every buzzword of Clavian mathematics:

The [Pythagoreans] rejected false consonances, and demonstrating the true, with most evident reasons founded upon the infallibility of number, they proceeded to establish, as in the other sciences, the basis for certain principles, with the necessary definitions, truest axioms, and most useful propositions, from which are drawn evident and completely irrefutable demonstrations.

From this, as is clear, you can conclude with certainty that music is effectively a science, because he who understands it and treats it as such "understands the matter through the cause by which it is, and other than which it cannot be." ...

... Suffice it to say with Aristotle that "music is one of the mathematical sciences." This is so because [music] considers quantity, the universal object of all the mathematical sciences. ${ }^{146}$

144. Melani, letter to Matthias de' Medici of August 31, 1658, quoted in Freitas, Portrait of a Castrato, 161. Freitas discusses Melani's efforts to "get out of the rank of musico" extensively (ibid., 3-5, 88-100, 149, 161, 196-97, 326-27); I borrow the term "contamination" from him.

145. Timms, Polymath of the Baroque, 63.

146. Steffani, Quanta certezza, 23-25: "Così rigetorono i falsi Concenti, e dimonstrando i Veri, con raggioni evidentissime, fondate sopra l'infallibilità de Numeri, andarono formando à questa, come alle altre Scienze, la Base di Principii Certi, con le necessarie Definizioni, i verissimi Assiomi, e le utilissime Proposte, da quali poi si cavano evidenti, \& incontrastabilissime Dimostrazioni. Da ciò che chiaramente apparisce, può lei dunque sicuramente conchiudere, che la Musica effettivamente è Scienza, perche Chi la conosce, e la tratta Così, cognoscit Rem per 
At times Steffani proved Zarlinian doctrine through the weight of marvelous correspondences. Of the senario he observed that six were the jars of water that Christ turned to wine at Cana; the uterus takes on perfect human form in forty-five days, which, multiplied by six, yield the full period of gestation: nine months of thirty days. Could a musician of Steffani's caliber actually have believed this? Could such beliefs have been operative at a compositional level? They were among the truths, remarked Steffani, demonstrable by "anyone who, not content to be a composer, singer, or player, desires to be a musicus." ${ }^{\prime 47}$ His increasingly ambivalent relationship with his own professional identity - "composer, singer, player"-manifests itself in his too forceful affirmation of musical science. About a decade later Steffani even began to disguise his compositions under the name of his copyist, Gregorio Piva. ${ }^{148}$ To write off his Quanta certezza as "conservative" (and therefore uninteresting) would be to overlook his strategic refashioning through a coordinated use of music, mathematics, and manners, as in his flirtation with musical combinatorics.

Steffani drew content for Quanta certezza from the paratexts to his motet collection Sacer Ianus quadrifrons (Four-Faced Sacred Janus, 1685). He had organized the collection around a quasi-combinatorial conceit that yielded "forty-eight motets hidden in twelve," and therefore presented them as an exemplar of mathematical, musical scientia. ${ }^{149}$ At first glance the flexible scoring of Sacer Ianus would seem to make it marketable to establishments with modest resources. In fact it exemplifies the unique and spectacular gifts that made the client-patron relationship appear to exist in a state of grace (gratia) beyond mere economy and utility. ${ }^{150}$ (Just the sort of impression Bontempi gave of his relationship with Johann Georg II.) Timms, pained by Steffani's arrogance and avarice, expresses relief at their

Causam, propter quam ita res est, ut non possit aliter se habere. . . . Basta che si dica con Aristotele Musica appellatur ipsa quae Mathematicarum Scientiarum Una est. Ella è tale, perche considera la quantita' oggetto Universale di tutte le Mattematiche." (Italics in translation mine.) Cf. Zarlino, Le istitutioni harmoniche, bk. 1, ch. 1, 4.

147. Steffani, Quanta certezza, 47-63, here 63: "e credo certo, che chiunque hà voglia d'esser Musico, non contentandosi d'esser Compositore, Cantore, ò Suonatore possa sperimentarlo con grandissima facilità." Timms suggests that Steffani's Stabat Mater has a senary resonance: Timms, Polymath of the Baroque, 166. For other explorations of the relationship between musical proportions and human gestation by musicians, see Picitono, Fior angelico di musica, ch. 2; Zarlino, Le istitutioni harmoniche, bk. 1, ch. 7, 16-18; Pisa, Battuta della musica dichiarata, 15; Liberati, "Epitome della musica," fol. 6r-v; and Tevo, Il musico testore, 6.

148. See Timms, Polymath of the Baroque, 96-97, 130-32.

149. Steffani, Sacer Ianus quadrifrons, "Benevolo Musicae Sectatori”: “48. Mottecta in 12. coacta." On the presentation of these motets as mathematical, musical scientia, see ibid., )(2r-v. The twelve motets are scored for three voices and basso continuo, but each can be performed in four ways without detriment to the harmony or text-by the full ensemble and by any combination of two voices and basso continuo.

150. See Biagioli, Galileo, Courtier, 36-54. 
passing. ${ }^{151}$ Yet as Biagioli demonstrates, demands for money, now apt to seem exorbitant and vain, were a crucial means of testing and validating one's persona. Wallflowers did not flourish at court. The actual compositions of Sacer Ianus - mere motets, after all-pale before the potential for a spectacular court demonstration in which Steffani could reveal the "hidden" music through combinatory art. And we should certainly imagine Steffani staging that demonstration to advance his fledgling diplomatic career in a polyglot world of codes, secrets, dissimulating courtiers, and spies. Combinatorics enjoyed great cachet at court, because, applied to linguistics, it seemed the most dazzling political tool of the age. As such, it occupied leading intellectuals such as Kircher, Caramuel, and Leibniz, the last of whom Steffani had almost certainly met through his diplomatic work at Hanover. ${ }^{152}$ Steffani presented his motets under the banner of the enigmatic Janus just as, under the guise of a musician, he hinted at a wider range of gifts and services.

Questions of professional identity colored the best-known example of musical combinatorics. Kircher's combinatorial method was the stimulus for his Musurgia, which in turn served as a calling card for his larger religious and political aims. Kircher advertised that he had not published the greatest refinements of his method, reserving them for powerful princes. He trained Johann Jakob Froberger in the use of his invention and then sent him to various courts as his emissary, to give select demonstrations of this wellpublicized but closely guarded secret. ${ }^{153}$ Kircher introduced this musica mirifica as rooted in the harmonious, necessary union of theory and practice: neither could truly achieve its end without the other. But the very possibility of reducing music to a numerical system directly challenged musicians' professional authority, which rested upon their claim to possess a formidable body of specialized technical knowledge "hardly [acquirable even] in many years of study." Not surprisingly, musicians reacted (so Kircher reported) with "laughter and derision." In response, Kircher claimed that his system revealed the much-vaunted knowledge of "mere practical composers"

151. Timms, Polymath of the Baroque, 16, 19, 26-27, 310-12. My specific disagreements notwithstanding, I very much admire Timms's work, as few scholars have taken so seriously the challenge of reconciling the multifarious aspects of a seventeenth-century musician's careerand Steffani's case presents particular complexities.

152. Broad studies of combinatorics with linguistic applications include Kircher, Polygraphia nova et universalis; Caramuel, Primus calamus; and Leibniz, Dissertatio de arte combinatoria.

153. Kircher, Musurgia universalis, 2:166-84. The published demonstration of Kircher's combinatory method reinforced the aura of social exclusivity: Bernardino Rocci of the Accademia degli Sterili (see note 101 above) composed a musical dialog, which enjoyed a successful hearing before the College of Cardinals, and was honored by the Roman Accademia degl'Intrecciati; see Carpano, Fasti dell'Accademia, 30. On Kircher's relationship with Froberger, see Annibaldi, "Froberger in Rome"; on Kircher's public secrets, see Wilding, "If You Have a Secret," and Malcolm, "Private and Public Knowledge," 305-7; and on Kircher's combinatory method of composition, see McKay, "Universal Music-Making." 
to be, in reality, attainable "in a short time and without work" by musical ignoramuses, boys, and (Oh, the indignity!) women. ${ }^{154}$

Musicians such as Steffani and Bontempi nevertheless found the professional tension that surrounded musical combinatorics useful in performing their courtly personae. Bontempi played both sides of the coin. On the one hand, in criticizing Kircher's scholarship he defended musicians' embodied knowledge as knowledge. ${ }^{155}$ (He praised Roman singers for practicing trills for an hour daily, often before a mirror.) On the other, he positioned himself advantageously among the elector's courtiers and intellectuals by making his print debut with a modest essay in musical combinatorics. His Nova quatuor vocibus componendi methodus (1660) has attracted attention mainly on account of its dedication to a "great composer," Heinrich Schütz. Yet even Wolfgang Witzenmann, who edited the facsimile, is exasperated by the paratexts that make up a quarter of the volume: he finds the dedication "not greatly informative" and a learned encomium "exceptionally long and ponderous . . . completely out of proportion to such a short treatise . . . without saying anything specific about the treatise itself." ${ }^{156}$ In fact, the paratexts inform a far different sense of the musically significant. It has gone unnoticed that Bontempi cribbed his introduction-and from none other than Martin Luther! ${ }^{157}$ A strange choice for a seventeenth-century Catholic, but a shrewd one for an Italian castrato among the courtiers of Lutheran Dresden. Admittedly, Bontempi's method yields modest musical results (four-voice settings, mostly homophonic, syllabic, and diatonic) and even then is dogged by limitations and complications. And yet Bontempi tells of years spent studying recondite theoretical matters, which he weighed "not on the common scale but on the goldsmith's balance"; he promises, like Kircher, to make a composer out of someone "completely ignorant in the art of music"; he hints at-but does not reveal-an expanded method that allows eight-voice composition "not like a Tyro, but like an expert in the art of Music." 158

154. Kircher, Musurgia universalis, 2:1-2: "Stimulum ad propositum exequendum addidit, Symphonetarum merè practicorum arrogans obiurgatio, ut dum putant, fieri non posse, ut Theoricus Melodiam eo artificio elegantia \& gratia componat . . . immo contrarium asserentes risu cacchinnisquè excipiant; ut hanc eorum obiurgationem falsam iniustamquè ostenderem. . . . Artem aliquam reperirem, qua quivis etiam quantumvis Musicae imperitus . . . exiguo temporis spacio \& sine labore consequi posset, quod practici Compositores vix multorum annorum spacio consequuntur . . . sive à Musicae peritis, sive ab eiusde $m$ ignaris, pueris etiam, \& Mulieribus.”

155. Bontempi, Historia musica, 169-70.

156. Witzenmann, "Introduction," xxvi.

157. Bontempi borrowed verbatim from Luther's Encomion musices (1538). Compare Bontempi, Nova . . methodus, "Benevolo Lectori," with Luther, Encomion musices, 320-23.

158. Bontempi, Nova ... methodus, "Benevolo Lectori”: “ex huius artis peritioribus hauserim, multosque annos . . . impenderim . . . me eandem non populari quadam trutinâ, sed aurificis staterâ accurato mentis acumine, certoque judiciô considerantem \& examinantem coëgit. ... . [S]i intellexero gratam tibi eam fuisse, copiosiorem octo vocibus componendi rationem 
Is all this just empty bragging? Not entirely, I think. Turning a learned ignoramus into a competent composer set the Nova . . methodus above mere practice because it obviated the craftsman's apprenticeship. Combinatorics accessed or mimicked the rules through which a potential infinity of possibilities might be brought into being. It was a form of natural magic, since it employed mathematics to produce marvelous effects similar to those that resulted from occult causes. ${ }^{159}$ An individual musical composition operated in the same way, though at a much lower level. Bontempi distinguished himself, then, with an instrument of magic and an efficient musical machine on "scientific" principles. To attempt a maximal reading of Bontempi's slight system: insofar as his numerical tables were generative matrices, his treatise rose above particular music and resembled Creation, which was saturated with potential music by virtue of sonorous number. Luther's borrowed words gave fitting voice to this cosmic vision: "nothing is without sound, or sonorous number; thus the air itself (the music of all things), though invisible, impalpable, and imperceptible to all the senses . . . becomes, if moved, sonorous and audible. . . . The spirit intimates wondrous mysteries through this matter, although this is not the place to discuss them." 160 That discussion remained for select gatherings in court, salon, and academy, where the Nova . . methodus would have been a curiosity worthy of conversation. Bontempi's paratexts testify to the social and hermeneutic currents in which his little treatise swam. The tide has since gone out, stranding a desiccated artifact.

\section{Origins and Enigmas}

In the preceding sections we have seen musicians shape their image through the written and spoken word. They appropriated and emulated the most conventional of materials. There were clear advantages in doing so, regardless of whether they actually believed in those conventions. That case has rested largely upon archival discoveries and textual analysis. Yet it everywhere brushes against questions of belief and mentalité that resist documentation. Georges Didi-Huberman's recent characterization of art-historical "knowledge"— "its

patefacere animum sumam, quà non ut Tyro, sed ut artis Musicae peritus compositionem tibi comparare potueris."

159. See Gouk, Music, Science and Natural Magic, ch. 3, and Hankins and Silverman, Instruments and the Imagination, chs. 1-2.

160. Bontempi, Nova . . methodus, "Benevolo Lectori": "cùm nihil sit sine sono, seu numero sonoro, ita ut \& aër ipse per sese invisibilis \& impalpabilis, omnibus sensibus imperceptibilis, minime que omnium Musicus . . . tamen motus sit sonorus \& audibilis . . miranda in hoc significante Spiritu mysteria, de quibus hic non est dicendi locus." I suspect the discussion of free will that opens Bontempi's Historia musica (1-4) reflects, in some way, his interactions with Lutheranism. 
inherent fragility with regard to all procedures of verification, its extremely lacunary character"- could serve equally for our study of Berardi. ${ }^{161}$ Archival information certainly clarifies Berardi and his writings, but it also vexes our relationship to them. This final section entertains a more speculative possibility: that these conventional writings offer glimpses of the furniture of a seventeenth-century musician's mind. Moreover, the intellectual, spiritual, and metaphysical tendencies they present-especially where they broach a disembodied, dematerialized, inaudible music - remind us that important realms of musical meaning must remain elusive for the historian, difficult to access and to integrate into the modern life of old music. This possibility involves a vigorous embrace of uncertainty, akin to what Didi-Huberman describes as "the paradoxical ordeal not to know . . but to think the element of not-knowledge."162

Berardi frequently tied physical signs and sounds to metaphysical verities. It is not always easy to decide how far to take such passages. In his Ragionamenti he remarked that the papal chapel was the "symbol of that holiest chapel of heaven," because it forbad "material instruments": thus a cappella music more closely resembles the disembodied voices of the angelic intellects perched high on The Great Chain of Being. ${ }^{163}$ Although Berardi himself published volumes of concerted liturgical music, this idea is nevertheless consonant with the metaphysical orientation toward a dematerialized music that we have seen. And indeed Berardi wrestled with music's embodiment throughout this treatise. ${ }^{164}$ Many of our writers were in fact clerics indoctrinated with the Pauline duality between flesh and spirit, consecrated to the great mystery of Incarnation, vowed to embodying these tensions in their own renunciations and mortifications. For them, sounding music may have always had ipso facto something of this problematic; it needed always to point beyond itself.

Thus, in an apparently straightforward explanation of accidental signs Berardi noted the power of signs generally to carry us beyond appearances to "ideas." He quoted Augustine's definition of a sign as "that which, beyond the understanding that it brings to the senses, brings us even unto the understanding of something else." 165 It bears comparison to a definition of a symbol found in Kircher's Egyptological writings: "[its] nature is to lead our soul . . . to the understanding of something very different from that

161. Didi-Huberman, Confronting Images, 1-7, here 2.

162. Ibid., 7.

163. Berardi, Ragionamenti musicali, 168-70: "La Cappella Ponteficia è simbolo di quella Sacrosanta Cappella del Paradiso ... . il canto de gli Angeli non è accompagnato dall' Organo, nè da altro Instrumento materiale."

164. See, for instance, ibid., 92-98, 137-41, 156-60.

165. Berardi, Miscellanea musicale, 59: "Il b, molle, e b, quadro s'addimandano segni, poiche oltre quella spetie, che si rappresentano all'occhio, un'altra ce ne rapportano all' Idea, e perciò Sant'Agostino [libro] 5. [recte 2] de doctrina Christiana capitolo I. disse: Signum est illud, quod praeter cognitionem, quam ingerit sensibus, facit nos etiam venire in cognitionem alterius." Berardi's comments opened a discussion of music related to the Scacchi-Micheli dispute, examined on pages 112-15 below. 
which presents itself to our exterior senses, and whose property is to lie concealed and hidden under the veil of an obscure expression." "66 Moreover, in Father Berardi's day Augustine's definition explained the truly miraculous coexistence of commonplace appearances with divine substance in the Eucharist. That's a lot of firepower for little B $b$ ! Did Berardi overshoot his mark in trying to say merely that accidental signs indicate that "something else" should be sung? ${ }^{167}$ Or was he aiming higher still, reminding readers that something celestial cohered also in musical signs? Whatever the truth of the matter, it is worth our considering readings of musical phenomena that led into the obscure realm of symbols, signatures, sympathies, and correspondences. These pervaded philological and antiquarian thought, as in Johann Peter Erich's Renatum è mysterio principium philologicum (Philological Origins Recovered from Mystery, 1686). Erich's excavation of the F ("fa") clef led ineluctably to most ancient roots: symbols, he argued, preceded both signifying sounds and the letters that represented them; the seven pitch names $(A, B, C, \ldots)$ constituted the first elements of the sacred antediluvian idiom. ${ }^{168}$

Music historians have, with good reason, attempted to survey the state of music-historical knowledge among Baroque musicians: what did a Bach or Monteverdi know of earlier composers, works, and styles? But the selection effect is at work here, since the woollier aspects of early modern historiography inevitably fall by the wayside. ${ }^{169}$ Who invented music? It was a perennial topic of musical conversation in Berardi's day. The term "inventor" was multivalent, signifying original creation, divine inspiration, and discovery of preexisting objects. In the case of music those objects were of a very high order of significance. The truly epochal inventions of music history came as revelations of mathematical knowledge vouchsafed through the vast unfolding of Providence. For Bontempi, the biblical Jubal had "invented" music insofar as God granted him the abstract "science" that stood above the materiality of sounding music. This science was "formed from true and real essences that, rendered above the consideration of material matters into purest essences of reason by the human intellect, can never lose their true and real essence, as being of divine and immortal quality." ${ }^{170}$ Jubal was not chosen

166. Kircher, Obeliscus Pamphilius, 115: "Natura symboli est, conducere animum nostrum . . . ad intelligentiam alicuius rei, multum à rebus, quae sensibus offeruntur exterioribus, differentibus; cuius proprietas est, esse celatum, \& absconditum, sub velo obscuri dicti" (Kircher's italics).

167. Cf. the extended metaphor on accidentals in Berardi's Ragionamenti musicali (117), in which Felice compares accidental signs to meteorological and atmospheric phenomena, such as rain and drought, a comparison described by his interlocutor Giuseppe as a pleasant "scherzo."

168. Erich, Renatum è mysterio, 16-22; on the treatise more generally, see Eco, Search for the Perfect Language, 189-90.

169. For a notable exception, see McKinnon, "Jubal vel Pythagoras."

170. Bontempi, Historia musica, 46: "per esser formata d'Enti veri, e reali, che resi dall'intelletto humano sopra la consideratione delle conditioni materiali, in Enti purissimi di ragione, 
by accident, we learn from Berardi: as part of the eighth generation of humankind, Jubal formed the octave to God's unison. Berardi tells us that Jubal engraved musical revelation on columns of brick and marble to preserve them from the Flood and Fire foreseen by Adam. All this goes considerably beyond the literal biblical account. Once again, then, Berardi is utterly conventional: like many contemporaries he drew his historical and scientific understanding (now just so much quaint lore) from the Margarita philosophica, a university textbook already nearly two centuries old. ${ }^{171}$

The mentalités of those who made seventeenth-century music (to the extent that we can access them) resist easy integration into musicology, which combines historical study with living performance and connoisseurship. And so there exists the sobering possibility that contextual study reveals the impossibility — perhaps undesirability — of hearing seventeenth-century music "accurately." The gulf between our interpretive worlds has been captured in Lorenzo Bianconi's famous remark that "competent judgments on contemporary music are conspicuously absent through the seventeenth century. ... [T] he seventeenth century is literally without words to describe the specific qualities of a musical composition." ${ }^{172}$ We savor the details repeatedly; seventeenth-century connoisseurship (as in Chiavelloni's Discorsi) depended upon moving beyond the particular and specific. Marvel and the rapture it provoked were chief goals of seventeenth-century listening. These ecstatic spiritual states marked music's supernatural force. Although the experience of them was often described as lying beyond reason and explication, their mathematical-magical causes were in fact eminently explicable: because musical sound contained God's signature, it drew the soul as if by magnetism. ${ }^{173}$ The universe, Berardi explained in his most Kircherian vein, having been composed according to laws of consonance and dissonance, yielded "innumerable and unutterable beauties, grandeurs, and marvels." ${ }^{174}$ Music was not drastic or gnostic: it was drastic because it was

non possono mai perdere la loro vera e reale essentia, come qualità divina \& immortale." "Ente" carries connotations of the "ens" of scholastic philosophy.

171. On Jubal and the columns, see Berardi, Miscellanea musicale, 24-25; Liberati, "Epitome della musica," fol. 10r; Macchetti, "Curiosità musicali," MS 248, fols. 7r-v, 174r-v; Tevo, Il musico testore, 10-19; and Bourdelot, Bonnet-Bourdelot, and Bonnet, Histoire de la musique, 87-88.

172. Bianconi, Music in the Seventeenth Century, 61-62.

173. On marvel and rapture in seventeenth-century listening, see Dell'Antonio, Listening as Spiritual Practice, ch. 1. Kircher, again, provides a good index for these ideas: see his discussion of mode, affect, and listener response in the music of Carissimi (Kircher, Musurgia universalis, 1:603); the account of his own ecstatic experience as a listener, and its relationship to his studies of astronomy (Kircher, Itinerarium exstaticum, 33-35); and his discussion of the magnetic powers of music and love (Kircher, Magnes, bk. 3, pts. 8-9, 840-906).

174. Berardi, Miscellanea musicale, "Al cortese, e benigno lettore": "innumerabili, \& indicibili bellezze, grandezze, e meraviglie." 
gnostic. ${ }^{175}$ Berardi rooted musical epistemology in marvel and professional class, borrowing again from Tesauro, nobleman-theorist of the marvelous: "Marvel was the mother of the liberal arts, whence comes the axiom 'Through admiration man began to philosophize.' Necessity, however, was the mother of the servile arts, whence that other axiom, 'Necessity makes a man industrious.' . . . Among the mechanical arts music will not be found; it will be found rather among the liberal arts." ${ }^{176}$ Marvel as a paradigm for aesthetic reception had import for musical meaning (that is, for attempts to explain the significance of individual compositions or events). And here we take one final look at the way Berardi refashioned his Scacchian inheritance.

Berardi borrowed from the texts of the Scacchi-Micheli polemic, a dispute in which the nature and limits of musical meaning were hotly contested. Micheli had composed a canon ("Pater et Filius") to a text on the indivisible unity of the Holy Trinity. It required three voices but could not admit a fourth. He (like Monteverdi) claimed to have observed Plato's doctrine that music must submit to text. ${ }^{177}$ Scacchi challenged Micheli's reading of Plato and adhered to one closer to Monteverdi's: that harmony itself must bear meaning. ${ }^{178}$ And he went on to attack canon itself. Since canons often yield poor harmony they fail to fulfill music's chief purpose, which is to delight the hearing (and only then the intellect). As exercise, canons could keep a composer fit; beyond that they should be used "rarely, only to demonstrate that one understands them, but not for daily bread, since they render pieces dry." 179

Not that Scacchi was above constructivist devices. Far from it: they featured in some of the compositions of which he was proudest. The score of his motet "Vobis datum est noscere misterium" (To you it is given to know a mystery) includes a wayward tenor who appears to fall out of tune with an ensemble that traverses the chromatic circle of fifths. They sing Christ's words "to others I

175. I borrow the terms "drastic" and "gnostic" from Carolyn Abbate's seminal article "Music-Drastic or Gnostic?"

176. Berardi, Aggiunta, 15-16: "La Maraviglia fù Madre dell' Arti Liberali, onde ne viene quell' assioma: Per l'ammirare cominciò l' huomo à filosofare. Mà la necessità fù Madre dell' Arti servili, onde è quell'altro: La necessità fà l' huomo industrioso. . . . [F]rà le Mecaniche non vi trovarà la Musica, la rintracciarà bensì frà le Liberali."

177. Giuseppe Gerbino observes of a similar Micheli canon criticized by Scacchi ("Iste est qui magna sapit terrena") that "the music does not imitate the words but conforms, by means of analogy, to an abstract concept of which the words are already a concise and aphoristic formulation": Gerbino, Canoni ed enigmi, 101 ("la musica non imita le parole ma si conforma per via analogica ad un concetto astratto di cui le parole sono già un'enunciazione sintetica ed aforistica").

178. See Micheli, "Risposta," fols. 18v-19v.

179. Scacchi, Considerationi, as given in Micheli, "Risposta," fol. 16r-v: "La Musica fù inventata non per altro, che per dilettare. ... [S] ebene queste intelligenze ingrandiscano l'arte Musicale, nientedimeno si devono usare di rado, per mostrare solamente, che l'huomo l'intende, e non per pasto quotidiano, perche tali studii rendono le Cantilene perlo più aride" (underlined in source). 
speak in parables [parabolis], so that seeing they will not see and hearing will not understand" (Luke 8:10). The error is only apparent: a discerning tenor would apply appropriate ficta. " 180 "Vobis datum" seems tailored to Tesauro's order, an exemplary figura parabolica that treats great truths under the guise of fables. ${ }^{181}$ Or is it? For his part, Scacchi repeatedly insisted that "the entire artifice" of "Vobis datum" consisted only "in deceiving the eye." 182 However easy it would have been, Scacchi avoided making deeper hermeneutic claims about his music's significance. He also expressed skepticism over Micheli's claims about his own. Micheli maintained that "Pater et Filius" amounted to an "occult mystery" that "represented the Most Holy Trinity under obscure symbols and hieroglyphs so that it should be understood only by the intelligent musician." ${ }^{183}$ Scacchi dismissed both Micheli's hermeneutic claims about individual canons ("I do not understand this sublime intelligence of things nearly impenetrable, like those of heaven") and the attitude that went with them ("these professors ... deem it a serious sin if they do not attain sublimity in their canons, which they consider to be musical oracles"). ${ }^{184}$ No wonder Scacchi found Micheli's hermeneutics preposterous. It does not require much intellectual subtlety to divine the relationship between a three-voice canon and a Trinitarian text. Micheli offered little of the oracle's multivalent mystery, yet promised abundant exegetical resonance.

If Micheli and Scacchi despised each other, Micheli admired Kircher with good reason. ${ }^{185}$ As a linguist, scientist, and antiquarian, Kircher adopted the pose of cryptographer whether deciphering or encoding. In every enterprise, he seized upon the "hieroglyphic," "hidden," "recondite," and "arcane" as being of singular value. Far-flung phenomena best expressed hidden relationships between apparent variety and actual unity. Beneath the sprawling

180. This compositional conceit bears comparison with that found in Micheli's canonic madrigal "O voi che sospirate" (1621). Scacchi, however, encountered a much earlier example in Artusi-Willaert's “Quid non ebrietas.” While expressing admiration for Micheli's madrigal he therefore rejected his claim of priority. Scacchi, Declaratio cantilenae, fols. $21 \mathrm{v}-22 \mathrm{v}$, and "Raggionamenti," fols. 24r-25v.

181. Tesauro, Il cannocchiale aristotelico, 503: "Peroche passa gran differenza trà l'insegnar Favole, \& l'insegnar la Verità con le Favole."

182. Scacchi, Declaratio cantilenae, fol. $23 \mathrm{r}$ and again at fol. $25 \mathrm{v} / \mathrm{Ev}$ : "Totum enim artificium in eo praecipuè consistit, ut oculus decipiatur"; see also the title page and folio $22 \mathrm{r}$; he is speaking also of his motet "Domine Deus."

183. Micheli, Avviso, A2v-A3r: "occulto mistero"; "Io hò voluto, che il mio Canone rappresenti la Santissima Trinità, sotto oscuri simboli, \& geroglifici, acciò non sia inteso, se non dal Musico intelligente."

184. Scacchi, Considerationi, quoted in Micheli, "Risposta," fols. 13v, 15v: "Non conosco questa sublime intelligenza di cosa quasi non penetrabile, à similitudine dell'opere del Cielo. . . . [Q]uesti Professori . . . pare che sia peccato grave ad alcuni, se non sollevano in sublimità li loro Canoni, li quali credono d'essere Oraculi della Musica" (underlined in source).

185. Micheli also sent his work for approval to Caramuel and Mersenne; see Caramuel y Lobkowitz, "Musica," bk. 1, art. 11, and a letter from Mersenne to Micheli of ca. 1648 bound with Micheli, "Risposta," fol. 106r. 
surface of seventeenth-century encyclopedism and collezionismo lay, as Sabaino observes, "the conviction that among all disciplines there exists a unitary root of knowledge." ${ }^{186}$ It engendered a cryptographic habit of reading both the physical present and the historical past.

Berardi, in taking over the Scacchi-Micheli polemic, again faced a discrepancy between his raw materials and the public figure he wished to project. So although he eulogized Scacchi, he fashioned himself rather after a Kircher or a Micheli. Like Kircher, he created in his writings a wunderkammer for musical treasures likely to provoke curious civil conversation. ${ }^{187}$ Scacchi's music offered a suitably marvelous treasure, even if his interpretive claims did not quite suffice. Once again, then, Berardi recomposed Scacchi to benefit his own persona. He presented that in Scacchi's music which offered something uncommon, paradoxical, artificial. ${ }^{188} \mathrm{He}$ cited Scacchi's and Micheli's music together as proof that music was "profound," "a great and enduring treasure," and, like all true sciences, inexhaustible. ${ }^{189}$ In inexhaustibility lay the same asymmetry of combinatory music, between the unity of underlying principles and their limitless possibilities. Richness and diversity expressed unity best; the richer and more varied the parts, the more unlikely the paradox, the more powerful the unity that results. Berardi distanced himself from those who would "wear out their brains in dispute" about matters of musical style and technique: "Harmonic fundamentals," he wrote, "admit of neither controversy nor disagreement, since in all of musical science they are always the same." 190 There was little point in fighting over the various styles and practices. If musical arcana revealed the profound unity of musical science, they were ideally "revealed through friendship" (as promised on the title page

186. Sabaino, "Musica universalis, universus musicalis," 312: "la convinzione che esista tra tutte le discipline dello scibile una radice d'unità." The notion of "unum in omnia" appears in the works of many of the writers under discussion; see, for example, Mersenne, Questions harmoniques, 131, and Kircher, Polygraphia nova et universalis, title page. Tesauro, notably, expressed it as an anomphic emblem on the title page of his Cannocchiale aristotelico.

187. On seventeenth-century collecting with special reference to Kircher, see Findlen, Possessing Nature.

188. The same can be said of Berardi's overall treatment of counterpoint. In the Documenti armonici, ostensibly a contrapuntal manual for beginners, Berardi treats rudiments only after having discussed artifices such as "contrappunto alla zoppa" ("hobbling" counterpoint, which proceeds by leaps) and "contrappunto saltando" ("jumping” counterpoint, which procedes by very large leaps).

189. Berardi, Documenti armonici, 85: “Musica est res profunda . . . est etiam magnus, stabilisque thesaurus" (Berardi's italics); see also similar formulations in Berardi, Arcani musicali, 13, and Miscellanea musicale, 52. In the first two cases Berardi gave incorrect references to classical sources; in the third, where he copied directly from Garzoni (La piazza universale, 446), the references were more accurate.

190. Berardi, Il perché musicale, 50-51: "da lambicarsi il cervello nelle dispute"; Berardi, Arcani musicali, 5: "i Fondamenti Armonici non amettono nè controversie, nè dispute, essendo in tutta la scienza Musicale sempre i medemi." 
of the Arcani musicali), ${ }^{191}$ which shared the same property: in appearance many, in reality one. In Berardi's treatises, all antagonism between Micheli and Scacchi evaporates. Luckily, Scacchi did not live to witness it.

Thus we return to Berardi's Arcani musicali, the volume with which we began. "Arcane" no longer signifies something uncommon-and therefore central and essential. Rather it signifies something uncommon-and therefore peripheral and irrelevant. By observing seventeenth-century musicians' efforts to write and speak learnedly about music, we observe them in an activity that occupies us still. Yet our shared task opens onto a mental world that has largely vanished. Endemic plagiarism complicates our relation to sources and grates against our scholarly aesthetics (indeed, against the economies of our institutional world). Discarded notions of the musically significant are apt to appear even more opaque and perplexing. Artifacts of musical pasts survive in our musical culture like clasts fused at odd angles in layers of sedimentary rock. An apparent familiarity with seventeenth-century music disguises the unfamiliarity of seventeenth-century minds.

\section{Appendix: Scacchi's "Raggionamenti" transposed and transformed}

\section{Scacchi, "Raggionamenti," fols. 12v-13r Berardi, Ragionamenti (1681), 146-48}

Hanno li nostri Antichi intitolati alcuni Artificii musicali con il nome di contrapunti doppii, overo rivoltati alla. 2. 3. 4. 5. 6. 7. 8 . 9. 10. 11. et 12. et n'hanno dato una

Regola commune per conoscere quale [sic] consonanze, et disonanze se debbiano usare in detti contrapunti che' 1 è il rivoltare $\mathrm{i}$

numeri; poiche l'arte Armonica tutta consiste in un composto de numeri tanto consonanti, come disonanti, li quali uniti assieme rendono il concento Armonioso. ora volendo rivoltare il contrapunto all' ottava, si ponerà li numeri cosi

$$
\begin{array}{llllllll}
\text { 1. } & 2 . & 3 . & 4 . & 5 . & 6 . & 7 . & 8 . \\
\text { 8. } & 7 . & 6 . & 5 . & 4 . & 3 . & 2 . & 1 .
\end{array}
$$

Talche chiaro si vede, che nel contrapunto rivoltato all'ottava non si deve usare la quinta, la quale rivercio viene ad essere una $4 .^{\text {ta }}$ ignuda.

Il contrapunto alla Decima contiene in se 10. numeri li quali vanno posti con l'istesso ordine di sopra cioe.
Hanno li nostri Antichi intitolati alcuni Artificii musicali col nome di contrapunti doppii, overo rivoltati alla 2. 3. 4. 5. 6. 7. 8. 9. 10. 11 . et 12. \& hanno dato una regola commune, per conoscere quali consonanze, e dissonanze si devono usare in detti Contrapunti, ch'è rivoltare i numeri. Perche l'Arte Armonica tutta consiste in un composto di numeri tanto consonanti, come dissonanti, li quali uniti assieme rendono il concento armonioso. Hora volendo rivoltare il contrapunto all' ottava, si disporrano li numeri così: mi dia il tocca lapis

$$
\begin{array}{llllllll}
\text { 1. } & 2 . & 3 . & 4 . & 5 . & 6 . & 7 . & 8 . \\
\text { 8. } & \text { 7. } & 6 . & 5 . & 4 . & 3 . & 2 . & 1 .
\end{array}
$$

Talche chiaramente si vede, che nel Contrapunto rivoltato all'ottava non si deve usare la quinta, perche nel rivolto viene ad essere una quarta ignuda.

Il Contrapunto alla decima contiene in sè dieci numeri, quali vanno disposti col medesimo ordine, come sopra, cioè, 
1. 2. 3. 4. 5. 6. 7. 8. 9. 10 .

10. 9. 8. 7. 6. 5. 4. 3. 2. 1.

Dove che in questo contrapunto non si deve usare due terze, ne due seste seguenti una doppo l'altra.

Il contrapunto alla $12 .{ }^{\mathrm{ma}}$ consiste in $\underline{12}$. numeri cioe.

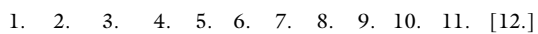

12. 11. 10. 9. 8. 7. 6. 5. 4. 3. 2. [1.]

Talche in questo contrapunto non si deve usare la 6. poi che nell'rivoltarllo diventa 7 .

\section{Scacchi, "Raggionamenti," fols. 21v-22r Berardi, Miscellanea (1689), 40-41}

Nell'età passata non si scorge altro che uno stile medesimo nelle Cantilene, et anco una scola commune in adoperare le consonanze, e dissonanze; e questo chiaramente si sente per l'opere, che sono alla luce.

Se pigliaremo il Divino Palestina $[$ sic $]$ come Autore non molto antico, ritrovaremo, che tra i suoi Madrigali, et li motetti, Aeciè poca differentia in quanto alla variatione dello stile;

se anderemo all'opere volgari in lingua francese, et Olandese, come son le Vingt et Six chansons Musicales \&c. et anco le Treziesme livre contenant Vingt et Deux chansons novelles a Six et a Hayt Parties. stampate nell'anno [1]545. 46. et 49. et nell'anno 1550. e 52. di differenti Autori; come sono Crecquillon, Ian Loys, Petit Ian de Latre; Jacques Vaet, Vulerant, Baston, Clemenz morel, Crispel, Nicolo, Rogier, Gallus, Claudin le Jeune; Clemens non Papa, Geraert, Hobrecht: Ant: Galli, Caulerin: Ciprianus de Rore, Lupi, Jannequin; Jusquino, manchicourt, Jan Gerard: Cabelian: Bays, Simon Cardon, M. Jacobi, Gombert, Timal Susato, Rocurt, Jan de Hollandi, Adriano, Noel, Baulduuin: Courtois, Jan Ockenheim, Verdelot, Castaleti, Joan Sueglin: et altri Autori, che per brevità si tralasciano.

Dico se ritrova in detti Autori qualche diferenza trà lo stile usato in quel tempo nella Chiesa, dà quello delle dette livre \&c. essendo ancora le parole in molte cantilene giocose, et ridicolose; et trà l'altri scherzi ciè la bella Margarita, la Gioronometta, la Battaglia di
1. 2. 3. 4. 5. 6. 7. 8. 9. 10 .

10. 9. 8. 7. 6. 5. 4. 3. 2. 1 .

Dove, che in questo Contrapunto non si deve usare due terze, nè due seste seguite una dopo l'altra.

Il Contrapunto alla duodecima consiste in dodici numeri:

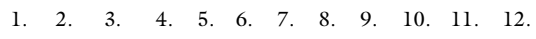

12. 11. 10. 9. $8.7 .6 .6 .4 . \quad 3.2 . \quad 1$.

Di modo tale, che in questo Contrapunto non si deve usare la sesta, poiche nel rivoltarlo diventa settima.

... il che non hanno fatto li nostri antecessori, ne quali non si scorge solo, che un medemo stile, \& una scola commune nell'adoprare le consonanze, e dissonanze; e ciò si prova dall'opere che sono alla luce.

Se pigliaremo il Palestrina Prencipe, e Padre della Musica, come autore non molto antico, trovaremo, che trà i suoi Madrigali, e motetti, vi è poca differenza, parlo in quanto alla variatione dello stile.

Se vederemo all'opere volgari in lingua Francese, \& Olandese, come le Vingt, \& Six Chansons Musicales \&c. \& anco le Treziesme livre contenant Vingt, et Deux Chansons novelles à Six, et a Hagit parties, stampate nell'anno 1545. 46. e 49.

E nell'anno 1550. e 52. di diversi Autori, come sono Crecquilon, Ianluys, Petit, Iandelatere, Jacques Vaet, Vulnerant, Baston, Clemenz Morel, Clemensnon Papa, Iusquino, Ian Gerard, Simon Cardon, Ricourt, Adriano, Noel Balduuin, Ian Ochenheim, Verdelot, e tanti altri Autori, che si tralasciano di diverse nationi,

considerando i loro componimenti, non vi è differenza alcuna frà le cantilene ecclesiastiche, e le volgari, levatene alcune, che hanno la modulatione un poco più gioconda, come la bella Margarita, la Girometta, la Battaglia di Clement Ian[nequin], e quella del Verdelot; 
Clement Iannequin et quella del Verdelot, e dal Gombert; et anco Unggai Bergier del Cricquillon: mà dove le parole sono serie si ritrova poca diferentia, trà li motetti, et messe dalle madrigali, circa lo stile, et il mettere delle con[son]anze, et dissonanze (come ho detto). Talche diremo, che gl'antichi, Autori havevono uno stile, et una sol Prattica nell'arte della Musica.

mà al secolo presente, vedesi quanto si è agumentata la Musica; poiche diremo, che li stilij della Musica d'hoggi dì, sono tre, cioe, di Chiesa, di Camera, e di Theatra. et le Prattiche sono due; la prima, ch'e l'Antica consiste, Ut Harmonia sit domina Orationis. et la Moderna, ut Oratio sit Domina Harmoniae.

Onde dico; che tutti questi stili vanno consideratie, et fabricati dall'Artefice differentemente. Lo stile di Chiesa si considera in 4 . modi variati . . .

\section{Scacchi, "Raggionamenti," fols. $24 v-25 v$}

Ora conforme la mia curiosità di mostrarò che l'arteficii di calare un Tono, e cosa antica, et anco come il Signor Don Romano l'habbia presa [. . .] dal primo inventore, ch'è stato il Divino Adriano. Circa quelli Eccelentissimi Virtuosi ch'affermano di non haver veduto tal' Arteficio (intendendomi per adesso del detto Madrigale solamente) Io humilmente li riverisco, et l'adoro per miei sublimi Maëstri; mà quello che si vede alla luce, nessuno potrà negarlo. Veniamo adesso alla prova.

Il detto Adriano hà composto un duo intitolato (quid non ebrietas?) l'arteficio di questa Cantilena consiste in questo, ch'il Tenore cala un Tono per mezzo de gl'accidenti maggiori; et il soprano resta nel suo luogo, et per curiosità delli studiosi ponerò in partitura il detto duo; et anco acciò la mia intentione sia intesa piu facilmente

\section{Duo del D: Adriano. \\ Quid non ebrietas?}

[Score follows. For brevity and clarity, I omit some text and a number of musical examples, which made their way into the Miscellanea and the Arcani musicali; see Table 5.]

$$
[\ldots]
$$

Chiara cosa è ch'il Signor Don Romano hà preso di peso l'inventione di far calar' un
E questo proviene, che le parole sono ridicole, e giocose, mà dove le parole sono serie, poca, ò niuna differenza si trova trà li motetti, Messe, e Madrigali circa lo stile, \& il mettere delle consonanze, et dissonanze.

Talche chiaramente si vede che i nostri Antichi havevono uno stile, \& una prattica sola.

Li moderni hanno trè stili, da Chiesa, da Camera, e da Teatro, le prattiche sono due; la prima, che è la vecchia, consiste, Ut armonia sit domina orationis: come hò detto di sopra; la seconda: Ut oratio sit domina harmoniae.

Tutti questi stili vanno fabricati, e tessuti dall compositore moderno differentemente.

Lo stile da Chiesa si considera in quattro modi ...

\section{Berardi, Documenti (1687), 78-80}

L'inventione di calare un tono, e antichissima.

Il Primo Inventore, fù Adriano Wilaert, Musico rarissimo, che ritrovo il modo di comporre à 2. chori, che ciascuno de se stessi accordasse.

Il sudetto Adriano compose un duo intitolato: Quid non ebrietas. L'artificio di questa cantilena consiste in questo, che il Tenore cala un Tuono per mezo degl'accidenti maggiori; $\&$ il Soprano resta nel suo luogo. Per curiosità degli studiosi ponerò in partitura il detto duo.

Quid non ebrietas.

[Score follows.] 


\section{Journal of the American Musicological Society}

Tono dal Don Adriano. ecco dunque che tale inventione è stata veduta altre volte et non è altrimente come dice, e se dichiara il detto Signor Don Romano; che tale artificio non sia stato più veduto. Sopra questa inventione dell'Adriano il Signor Don Romano ci hà aggiunto di componere la sua cantilena in Canone, et anco doppo calato il Tono di farlo ricrescere. questa speculatione non è molto sottile: prima perche una modulatione, che camina per intervalli di quinta, in quarta tramezzata con la terza, non è molto difficile à fabricarci sopra di essa un Canone. Et ecco per maggior chiarezza la modulatione del detto Canone cioè il motivo del detto Canon del Signor Don Roma[no] incomposto

$$
\text { [...] }
$$

E però vengo con facilità i suoi riversi con ogni naturalezza. perche il motivo è quasi l'istesso; mà considerandola per suo verso, non si può negare, che l'inventione ritrovata dal Don Adriano non sia miraculosa.

E benche Giovanni Spadaro sia stato, d'opinione ch'il finale dell'Adriano

Quando uscì alla luce il sudetto duo, Giovanni Spadaro fù d'opinione, che il finale concludesse in una comma Antica più grave di una ottava; non bisogna maravigliarci, dice l'Artusi; poiche deriva dalla scuola di Boëtio, conforme si legge in una sua lettera scritta a Don Pietro Aron l'anno 1524. et in vero il detto Spadaro à tempi suoi è stato di acutissimo ingegno nella musica conforme soleva dir'il Dottissimo Franchino. L'Artusi defende il detto Adriano con raggioni in vero molto evidenti; et chi è curioso di veder ogni cosa sopra questo particolare, legga l'imperfettioni della Musica del detto Artusi al primo Raggionamento a carte 21 . et subsequenti, ch'ivi ristarà sodisfatto. Dunque dirò che il signor Don Romano hà ła aggionto all'inventato; et quelli Signori eccellentissimi Virtuosi nominati di sopra li quali hanno affirmato di non haver veduto più simile inventioni. Io credo che habbiano inteso, ch'un Canone, come quello del detto Madrigale non l'habbia, ancora visto giustamente come l'hà stampato il Signor Don Romano; così credo dell'altre sue cantilene artificiose: ma non già hanno preteso li detti Signori, che l'inventioni fusserò trovate la prima volta dal Signor Don Romano.

concludesse in una comma antica, non bisogna maravigliarsi, dice l'Artusi, poiche derivava dalla scuola di Boetio, conforme si legge in una sua lettera scritta à Don Pietro Aron l'Anno 1524. Io però sono di parere, che la divisione del tuono in due parti eguali secondo l'opinione d'Aristossero, sia più propria per tessere Sinfonie per Istromenti, che cantilene per voci. 


\section{Works Cited}

Library sigla used in citations:

F-TOm Tours, Bibliothèque Municipale

I-Bc Bologna, Museo Internazionale e Biblioteca della Musica

I-CRg Cremona, Biblioteca Statale

I-PIu Pisa, Biblioteca Universitaria

I-Ra Rome, Biblioteca Angelica

I-Rar Rome, Archivum Romanum Societatis Iesu

I-Rasv Rome, Archivio Segreto Vaticano, Città del Vaticano

I-Rc Rome, Biblioteca Casanatense

I-Rpug Rome, Archivio della Pontificia Università Gregoriana

I-Rsc Rome, Biblioteca Musicale Governativa del Conservatorio di Musica Santa Cecilia

I-VIGsa Vigevano, Biblioteca Archivio Storico Capitolare

US-NHub New Haven, Yale University, Beinecke Rare Book and Manuscript Library

\section{Primary Sources}

Abbatini, Antonio Maria. Le lezioni accademiche (1663-68). In Antonio Maria Abbatini e la musica del suo tempo (1595-1679), edited by Galliano Ciliberti, 435-95. Perugia: Selci Umbro, 1986.

Artusi, Giovanni Maria. L'Artusi, overo Delle imperfettioni della moderna musica. Venice: Giacomo Vincenti, 1600.

[Audiffredi, Giovanni Battista]. Bibliothecae Casanatensis catalogus librorum typis impressorum. Vol. 1. Rome: Gioacchino and Giovanni Giuseppe Salvioni, 1761.

Avella, Giovanni d'. Regole di musica. Rome: Francesco Moneta, 1657.

Bacon, Francis. Sapienza degli antichi. Anonymous Italian translation of De sapientia veterum (1609). In Opere morali di Francesco Baccon, 115-259. Venice: Antonio Bariletti, 1639.

Bartoli, Daniello. Dell'huomo di lettere difeso et emendato. Rome: Heredi di Francesco Corbelletti, 1645.

Berardi, Angelo. Aggiunta . . alli suoi Ragionamenti musicali. Bologna: Giacomo Monti, 1681.

—. Arcani musicali. Bologna: Pietro Maria Monti, 1690.

—. Discorsi musicali composti, e recitati . . . da Angelo Berardi maestro di cappella dell'eminentiss. e reverendiss. sig. cardinal Brancacci. Viterbo: Martinelli, 1670. (= Discorsi 1670a. Exemplar: I-CRg Vol. FA.Ingr.O.2.1.)

- Discorsi musicali composti, e recitati in diverse accademie da Angelo Berardi . . . All'eminentiss. e reverendiss. sig. il signor card. Altieri. Viterbo: Martinelli, 1670. (= Discorsi 1670b. Exemplar: I-Rc Vol. Misc. 657.3, bound with Berardi's inscribed copy of Scacchi's Breve discorso.)

—. Discorso musicale composto, e recitato da Angelo Berardi . . . Dedicato all'illustrissima signora Anna Maria Marchese Costaguti Vidman. Viterbo: Pietro Martinelli, 1669. (= Discorsi 1669. Exemplar: I-CRg Vol. FA.Ingr.O.2.1.) 
- Documenti armonici. Bologna: Giacomo Monti, 1687.

. Miscellanea musicale. Bologna: Giacomo Monti, 1689.

- Missa pro defunctis. Rome: Ignatio de Lazeri, 1663.

—. Il perché musicale. Bologna: Pietro Maria Monti, 1693.

1675

Psalmi vespertini quatuor vocibus concinendi, op. 8. Rome: Angelo Muti,

. Ragionamenti musicali. Bologna: Giacomo Monti, 1681.

- Sacri concentus, op. 2. Rome: Ignatio de Lazeri, 1666.

- Salmi concertati à tre voci, op. 5. Bologna: Giacomo Monti, 1668.

-. Salmi vespertini, op. 4. Rome: Amedeo Belmonti, 1667.

- Sinfonie a violino solo, op. 7. Bologna: Giacomo Monti, 1670. Critical edition by Gregorio Carraro. Bologna: Ut Orpheus, 2011.

Biancani, Gioseffo. De mathematicarum natura dissertatio. Bologna: Bartolomeo Cocchi / Geronimo Tamburini, 1615.

Bononcini, Giovanni Maria. Arie, correnti, sarabande, gighe, ê allemande a violino e violone over spinetta con alcune intavolate per diverse accordature, op. 4. Bologna: Giacomo Monti, 1671.

—. "Discorso musicale sopra una composizione a 3, datagli per aggiungervi il

Basso; et in difesa della $3^{\mathrm{a}}$ sua opera uscita gia dalle stampe [e giudicata] non $d i$ lui ma tolta e rubata in buona parte da altri autori” (ca. 1669-70). In Giovanni Maria Bononcini of Modena: A Chapter in Baroque Instrumental Music, by William Klenz, 173-74. Durham, NC: Duke University Press, 1962.

-. Musico prattico, op. 8. Bologna: Giacomo Monti, 1673.

- Varii fiori del giardino musicale, overo Sonate da camera a 2, 3, e 4 col suo basso continuo, \& aggiunta d'alcuni canoni studiosi, \& osservati, op. 3. Bologna: Giacomo Monti, 1669.

Bontempi, Giovanni Andrea Angelini. Alcune lettere di G. Andrea Angelini al padre T. Macchetti camaldolense. Edited by Francesco Mariotti. Pisa: F. Mariotti, 1909.

- Historia musica. Perugia: Constantini, 1695.

- Nova quatuor vocibus componendi methodus. Dresden: Seyffert, 1660.

Bourdelot, Pierre, Pierre Bonnet-Bourdelot, and Jacques Bonnet. Histoire de la musique, et de ses effets. Paris: Jean Cochart, Étienne Ganeau, Jacque Quillau, 1715.

Burney, Charles. A General History of Music from the Earliest Ages to the Present Period. 4 vols. London: Printed for the Author, 1776-89.

- "Materials towards the "History of German music and musicians" (ca. 1770-90). US-NHub MS Osborn c. 100.

- "Remarks on Sr. J. Hawkins's 'General history of music'" (ca. 1776). US-NHub MS Osborn c. 101.

Caifabri, Giovanni Battista, ed. Sacras cantiones ab excellentissimi musices auctoribus... secunda pars ... per illustri, ac reverendo domino Angelo Berardo. Rome: Amedeo Belmonti, 1667.

Caramuel y Lobkowitz, Juan. "Musica” (ca. 1640-69). I-VIGsa III.2, III.7, and IV.6.

- Primus calamus ob oculos ponens metametricam. Rome: Fabio Falcone, 1663.

Carpano, Giuseppe, ed. Fasti dell'Accademia de gl'Intrecciati. Rome: Stamperia della Reverenda Camera Apostolica, 1673.

Cazzati, Maurizio. Risposta alle oppositioni fatte dal signor Giulio Cesare Arresti. Bologna: Heredi del Dozza, 1663. 
Sonate a due istromenti, op. 55. Bologna, 1670.

“Censurae Librorum 1650-1654.” I-Rar Fondo Gesuitico 668.

Cerone, Pietro. El melopeo y maestro. Naples: Giovanni Battista Gargano and Lucrezio Nucci, 1613.

Chiavelloni, Vincenzo. Discorsi della musica. Rome: Ignatio de Lazeri, 1668.

Clavius, Christoph. Euclidis elementorum libri XV. Rome: Vincenzo Accolti, 1574.

Coronelli, Vincenzo. Biblioteca universale, sacro-profana, antico-moderna. Vol. 5. Venice: Antonio Tivani, 1704.

Della Valle, Pietro. "Libri, che ho letti, e studiati in tempo di mia vita, per quanto posso ricordarmi" (1630-51). I-Rasv ADV 92, fascs. 1-2, fols. 30r-49v.

Desideri, Girolamo. "Della musica." In Prose de' signori Accademici Gelati di Bologna, edited by Valeriano Zani, 321-56. Bologna: Manolessi, 1671.

Erich, Johann Peter. Renatum è mysterio principium philologicum. Padua: Ex Typographia Seminarii, 1686.

Fétis, François-Joseph. Biographie universelle des musiciens et bibliographie générale de la musique. 8 vols. Paris: H. Fournier, 1835-44.

Garzoni, Tommaso. La piazza universale di tutte le professioni del mondo, e nobili et ignobili. Venice: Giovanni Battista Somascho, 1586.

Glielmo, Antonio. Le grandezze della Santissima Trinità (1634). 2nd ed. Naples: Roberto Mollo, 1639.

Gratiani, Bonifatio. Antifone della Beatissima Vergine Maria . . al signor D. Angelo Berardi, op. 13. Rome: Iacomo Fei d'Andrea figliolo, 1665.

Psalmi vespertini, op. 5. Rome: Iacomo Fei d'Andrea figliolo, 1666.

Gumpelzhaimer, Adam. Compendium musicae latino-germanico (1591). 11th ed. Augsburg: Johann Weh, 1655.

Kepler, Johannes. Harmonices mundi. Linz: Gottfried Tambach, 1619.

Kircher, Athanasius. Correspondence. I-Rpug MSS 555-568.

-. Itinerarium exstaticum. Rome: Vitale Mascardi, 1656.

- Magnes. Rome: Lodovico Grignani, 1641.

. Musurgia universalis. 2 vols. Rome: Eredi di Francesco Corbelletti / Lodovico Grignani, 1650.

- Obeliscus Pamphilius. Rome: Lodovico Grignani, 1650.

- Polygraphia nova et universalis. Rome: Varesi, 1663.

Kuhnau, Johann. Der musicalische Quack-Salber. Dresden: Johann Christoph Miethen and Johann Christoph Zimmermann, 1700.

Leibniz, Gottfried Wilhelm. Dissertatio de arte combinatoria. Leipzig: Johann Simon Fick and Johann Polycarp Seubold, 1666.

Liberati, Antimo. "Epitome della musica raccolta da Antimo Liberati" (ca. 1665). Edited by Massimo Redaelli from I-Bc MS D.92/A (an eighteenth-century manuscript copy). Accessed August 2, 2015. http://mimtt.co.uk/files/Liberati _Epitome.pdf.

- Lettera scritta dal sig. Antimo Liberati in risposta ad una del sig. Ovidio Persapegi. Rome: Mascardi, 1685.

Liberati, Antimo, Matteo Zani, Arcangelo Corelli, and Giovanni Paolo Colonna. "Diverse lettere intorno ad una Controversia nata sopra un passo dell'opera seconda di Arcangelo Corelli" (1685). Edited by Massimo Redaelli from I-Bc MS D.1. Accessed August 23, 2015. http://mimtt.co.uk/files/Corelli_Lettere.pdf. 
Loredano, Giovan Francesco. Bizzarrie academiche. Venice: Giacomo Sarzina, 1638.

Luther, Martin. Encomion musices (1538). In Luther's Liturgical Music: Principles and Implications, by Robin A. Leaver, 313-24. Grand Rapids, MI: William B. Eerdmans, 2007.

Macchetti, Teofilo. “Curiosità musicali” (ca. 1694-1712). I-PIu MSS 248-249.

Mattheson, Johann. Der vollkommene Capellmeister: Das is gründliche Anzeige aller derjenigen Sachen, die einer wissen, können, und vollkommen inne haben muß, der einer Capelle mit Ehren und Nutzen vorstehen will: Zum Versuch entworffen von Mattheson. Hamburg: Christian Herold, 1739.

Melpomene coronata da Felsina: Cantate musicali à voce sola, date in luce da signori compositori bolognesi. Bologna: Giacomo Monti, 1685.

Mersenne, Marin. Correspondance du P. Marin Mersenne Religieux Minime. Edited by Cornelis de Waard and Armand Beaulieu. 17 vols. Paris: G. Beauchesne, 1932-88.

- Questions harmoniques. Paris: Iaques Villery, 1634.

Micheli, Romano. Avviso inviato da me Romano Micheli . . . alli famosi e peritissimi signori musici d'Italia. Rome: Lodovico Grignani, 1650.

—. "Risposta fatta da me Romano Micheli per informatione Alli famosi, e peritissimi Signori Musici d'Italia" (1648). I-Ra MS 500.

Morley, Thomas. A Plaine and Easie Introduction to Practicall Musicke. London: Peter Short, 1597.

Nassarre, Pablo. Escuela música, según la práctica moderna. 2 vols. Zaragoza: Herederos de Manuel Roman / Herederos de Diego de Larumbe, 1723-24.

Novelle amorose de' signori Accademici Incogniti. 2 vols. Venice: Guergli, 1650.

Ouvrard, René. "La musique rétablie depuis son origine / Harmonica scientia à fundamentis restituta" (ca. 1664-94). F-TOm MSS 821-822.

Pallavicino, Sforza. Considerazioni sopra l'arte dello stile e del dialogo. Rome: Eredi del Corbelletti, 1646.

- Del bene. Rome: Eredi di Francesco Corbelletti, 1644.

Pellicani, Giovanni Battista Sanuti. "De gl'intervalli musicali." In Prose de' signori Accademici Gelati di Bologna, edited by Valeriano Zani, 133-39. Bologna: Manolessi, 1671.

Picerli, Silverio. Specchio secondo di musica. Naples: Matteo Nucci, 1631.

Picitono [Pizzighettone], Angelo da. Fior angelico di musica. Venice: Agostino Bindoni, 1547.

Pisa, Agostino. Battuta della musica dichiarata. Rome: Bartolomeo Zannetti, 1611.

Reisch, Gregor. Margarita philosophica. Freiburg: Johann Schott, 1503.

Rossi, Giovanni Battista. Organo de cantori. Venice: Gardano / Bartholomeo Magni, 1618.

Scacchi, Marco. Breve discorso sopra la musica moderna. Warsaw: Pietro Elert, 1649. (Exemplar: I-Rc Vol. Misc. 657.4, inscribed by Angelo Berardi.)

- Brief Discourse on Modern Music. Annotated English translation of Scacchi's Breve discoro by Claude V. Palisca. In Words and Music: The Scholar's View, edited by Laurence Berman, 189-235. Cambridge, MA: Harvard University Department of Music, 1972.

- Brief Discourse on the Modern Music. Annotated English translation of Scacchi's Breve discorso by Tim Carter. In Polemics on the "Musica Moderna," 31-69. Kraków: Musica Iagellonica, 1993. 
Cantilena V. voc. \& lachrymae sepulchrales, hoc est Canones aliquot multipliciter variati honori et memoriae Johannis Stobaei Grudentini Borussi. Königsberg: Paschalis Mense, 1647. (Exemplar: I-Rc M.XIII.117.)

- Cribrum musicum. Edited and translated by George R. Boyd. In "The Scacchi/Siefert Controversy with Translations of Marco Scacchi, Cribrum musicum, and Paul Siefert, Anticribratio musica." PhD diss., Indiana University, 1996.

- Cribrum musicum ad triticum siferticum. Venice: Alessandro Vincenti, 1643. (Exemplar: I-Rc M.V.61, inscribed and annotated by Angelo Berardi.)

- Cribrum musicum: Kommentierte lateinisch-deutsche Edition der Ausgabe Venedig $1643 \mathrm{inkl}$. Auflösung des Rätselkanons. Edited and translated by Michael Heinemann. Cologne: Dohr, 2014.

—. Declaratio cantilenae quinq. vocum, Vobis datum est, \&oc. Königsberg: Paschalis Mense, 1650. (Exemplar: I-Rc M.VI.30.)

- Indicium cribri musicum. Warsaw: Pietro Elert, ca. 1649. (Exemplar: I-Rc M.V.61.)

- Iudicium cribri musicum. Edited and translated by Michael Heinemann. In Iudicium cribri musici: Dokumente zum Streit zwischen Marco Scacchi und Paul Siefert: Kommentierte lateinisch/italienisch-deutsche Edition der Schriften von Paul Siefert, Marco Scacchi und Hieronymus Ninius. Cologne: Dohr, 2014.

- Missarum quatuor vocibus. Rome: Giovanni Battista Robletti, 1633. (Exemplar: I-Rc Mus. 586, annotated.)

- "Raggionamenti" (ca. 1648-49). I-Rsc MS G 34.

Schott, Gaspar. Cursus mathematicus, sive Absoluta omnium mathematicarum disciplinarum encyclopaedia. Würzburg: Erben von Johann Gottfried Schönwetter, 1661 .

Steffani, Agostino. Quanta certezza habbia da suoi principii la musica. Amsterdam, 1695.

-. Sacer Ianus quadrifrons. Munich: Johann Jäcklin, 1685.

"Supplementum generale ad catalogum typis editum librorum impressorum Bibliothecae Casatensis [sic].” Vol. 1. I-Rc MS 5063/1.

Sylvestris, Florido de, ed. Psalmos istos ab excellentissimis musices auctoribus. Rome: Ignatio de Lazeri, 1662.

Tesauro, Emanuele. Il cannocchiale aristotelico (1654). 5th ed. Turin: Bartolomeo Zavatta, 1670.

- La filosofia morale derivata dall'alto fonte del grande Aristotele Stagirita. Turin: Bartolomeo Zapata, 1670.

Tevo, Zaccaria. Il musico testore. Venice: Antonio Bortoli, 1706.

Uberti, Grazioso. Contrasto musico. Rome: Lodovico Grignani, 1630.

Vincenti, Alessandro. Indice di tutte le opere di musica, che si trovano nella stampa della Pigna di Alessandro Vincenti. Venice: [Vincenti], 1658.

Zacconi, Lodovico. Prattica di musica. Venice: Girolamo Polo, 1592.

Zarlino, Gioseffo. Le istitutioni harmoniche. Venice: [Pietro da Fino], 1558.

\section{Secondary Sources}

Abbate, Carolyn. "Music-Drastic or Gnostic?” Critical Inquiry 30 (2004): 505-36. Ago, Renata. "Possessions and Reputation: Making an Intellectual Persona in 17thCentury Rome." Working paper presented at the Italian Academy for Advanced 
Studies (Columbia University), October 12, 2011. Accessed March 4, 2016. http://italianacademy.columbia.edu/sites/default/files/papers/ago.pdf.

_ . "Tanti modi per promuoversi: artisti, letterati, scienziati nella Roma del Seicento." Accessed September 22, 2015. http://www.academia.edu/15721248/Tanti _modi_per_promuoversi._Artisti_letterati_scienziati_nella_Roma_del_Seicento.

Annibaldi, Claudio. "Froberger in Rome: From Frescobaldi's Craftsmanship to Kircher's Compositional Secrets." Current Musicology 58 (1995): 5-27.

Barbieri, Patrizio. "Pietro della Valle: The Esther Oratorio (1639) and Other Experiments in the 'stylus metabolicus.' With New Documents on Triharmonic Instruments." Translated by Ken Hurry. Recercare 19 (2007): 73-124.

Barnett, Gregory. Bolognese Instrumental Music, 1660-1710: Spiritual Comfort, Courtly Delight, and Commerical Triumph. Burlington, VT: Ashgate, 2008.

- "Giovanni Maria Bononcini and the Uses of the Modes." Journal of Musicology 25 (2008): 230-86.

Beretta, Ottaviano. "Introduzione." In Silverio Picerli: Specchio primo di musica (1630); Specchio secondo di musica (1631), vii-xxxii. Facsimile edition. Lucca: Libreria Musicale Italiana, 2008.

Biagioli, Mario. Galileo, Courtier: The Practice of Science in the Culture of Absolutism. Chicago: University of Chicago Press, 1993.

- "The Social Status of Italian Mathematicians, 1450-1600." History of Science 27 (1989): 41-95.

Bianchi, Eric. "Bad Latin, Bad Manners: Giovanni Battista Doni, Marin Mersenne, and Literary Style in Seventeenth-Century Music Theory." Music and Letters 96 (2015): 167-84.

- "Prodigious Sounds: Music and Learning in the World of Athanasius Kircher." PhD diss., Yale University, 2011.

Bianconi, Lorenzo. Music in the Seventeenth Century. Translated by David Bryant. Cambridge: Cambridge University Press, 1987.

Blair, Ann M. Too Much to Know: Managing Scholarly Information before the Modern Age. New Haven: Yale University Press, 2010.

Blasius, Leslie D. "Mapping the Terrain." In The Cambridge History of Western Music Theory, edited by Thomas Christensen, 27-45. Cambridge: Cambridge University Press, 2002.

Buelow, George J. "Chiavelloni, Vincenzo." Grove Music Online. Oxford Music Online. Oxford University Press. Accessed November 7, 2014. http://www.oxford musiconline.com/subscriber/article/grove/music/05566.

Christensen, Thomas. "Fragile Texts, Hidden Theory." Musica bumana 3 (2011): 177-207.

—. "Genres of Music Theory, 1650-1750." In Towards Tonality: Aspects of Baroque Music Theory, edited by Peter Dejans, 9-39. Leuven: Leuven University Press, 2007.

Ciliberti, Galliano. Antonio Maria Abbatini e la musica del suo tempo (1595-1679): Documenti per una ricostruzione bio-bibliografica. Perugia: Selci Umbro, 1986.

Cipollone, Barbara. "I Monti e la stampa della musica a Bologna nel secondo Seicento." Fonti musicali italiane 15 (2010): 61-139.

Cochrane, Eric. Florence in the Forgotten Centuries, 1527-1800: A History of Florence and the Florentines in the Age of the Grand Dukes. Chicago: University of Chicago Press, 1973. 
Crowther, Victor. The Oratorio in Bologna (1650-1730). Oxford: Oxford University Press, 1999.

Cypess, Rebecca. Curious and Modern Inventions: Instrumental Music as Discovery in Galileo's Italy. Chicago: University of Chicago Press, 2016.

Daolmi, Davide. "Sulla paternità degli ultimi drammi di Clemente IX: con un'appendice documentaria sul nipote Giacomo Rospigliosi." Studi secenteschi 46 (2005): 131-77.

De Angelis, Antonella. "Paolo Agostini di Vallerano ed altri musicisti di Tuscia." Biblioteca e società 14, fasc. 3-4 (December 1983): 17-22.

Dear, Peter. Discipline and Experience: The Mathematical Way in the Scientific Revolution. Chicago: University of Chicago Press, 1995.

- Mersenne and the Learning of the Schools. Ithaca and London: Cornell University Press, 1988.

Deleuze, Gilles. The Fold: Leibniz and the Baroque. Translated by Tom Conley. Minneapolis: University of Minnesota Press, 1993.

Dell'Antonio, Andrew. Listening as Spiritual Practice in Early Modern Italy. Berkeley: University of California Press, 2011.

Didi-Huberman, Georges. Confronting Images: Questioning the Ends of a Certain History of Art. Translated by John Goodman. University Park, PA: Pennsylvania State University Press, 2005.

Eco, Umberto. The Search for the Perfect Language. Oxford: Blackwell, 1995.

Fanti, Napoleone, Oscar Mischiati, and Luigi Ferdinando Tagliavini. Catalogo della Biblioteca musicale G. B. Martini di Bologna. Rev. ed. 4 vols. Bologna: Arnaldo Forni, 1961.

Findlen, Paula. Possessing Nature: Museums, Collecting, and Scientific Culture in Early Modern Italy. Berkeley: University of California Press, 1994.

Freitas, Roger. Portrait of a Castrato: Politics, Patronage, and Music in the Life of Atto Melani. Cambridge: Cambridge University Press, 2009.

Gerbino, Giuseppe. Canoni ed enigmi: Pier Francesco Valentini e l'artificio canonico nella prima metà del Seicento. Rome: Edizioni Torre d'Orfeo, 1995.

Gianturco, Carolyn. Alessandro Stradella, 1639-1682: His Life and Music. Oxford: Oxford University Press, 1994.

Gianturco, Carolyn, and Lucia Pierotti Boccaccio. "Teofilo Macchetti and Sacred Music in Pisa, 1694-1713." In Musicologia humana: Studies in Honor of Warren and Ursula Kirkendale, edited by Siegfried Gmeinwieser, David Hiley, and Jörg Riedlbauer, 393-415. Florence: Leo S. Olschki, 1994.

Goehr, Lydia. The Imaginary Museum of Musical Works: An Essay in the Philosophy of Music. Oxford: Oxford University Press, 1992.

Golub, Ivan. "Juraj Križanić's 'Asserta Musicalia' in Caramuel's Newly Discovered Autograph of 'Musica." International Review of the Aesthetics and Sociology of Music 9 (1978): 219-78.

Gouk, Penelope. Music, Science and Natural Magic in Seventeenth-Century England. New Haven: Yale University Press, 1999.

Grimaldi, Floriano. La cappella musicale di Loreto tra storia e liturgia, 1507-1796. 2 vols. Loreto: Fondazione Cassa di Risparmio, 2007.

- I codici musicali della cappella di Loreto. Loreto: Libreria Editrice Lauretana, 1984. 
Hankins, Thomas L., and Robert J. Silverman. Instruments and the Imagination. Princeton: Princeton University Press, 1995.

Heller, Wendy. Emblems of Eloquence: Opera and Women's Voices in SeventeenthCentury Venice. Berkeley: University of California Press, 2003.

Hellyer, Marcus. Catholic Physics: Jesuit Natural Philosophy in Early Modern Germany. Notre Dame, IN: University of Notre Dame Press, 2005.

Herissone, Rebecca. Music Theory in Seventeenth-Century England. Oxford: Oxford University Press, 2000.

Judd, Cristle Collins. Reading Renaissance Music Theory: Hearing with the Eyes. Cambridge: Cambridge University Press, 2000.

Linden, Huub van der. "Early Eighteenth-Century Music Type for the Printer Giuseppe Antonio Silvani: Correspondence and Other Documents." Tipofilologia 5 (2012): 27-66.

- "Profit, Patronage, and the Cultural Politics of Music Printing in Eighteenth-Century Italy: The Family and Finances of Giuseppe Antonio Silvani." In Specialist Markets in the Early Modern Book World, edited by Richard Kirwan and Sophie Mullins, 351-69. Leiden: Brill, 2015.

- "Sellers and Buyers of Italian Music around 1700: The Silvani Firm and G. B. Bassani's Music in Italy and Central Europe." In International Exchange in the European Book World, edited by Matthew McLean and Sara Barker, 282-305. Leiden: Brill, 2016.

Ludwig, Loren. “'Waies' and 'Meanes': Plainsong Canons and the Spiritual Significance of Cantus Firmus Polyphony in England c. 1600." Paper presented at the annual conference of the Society for Seventeenth-Century Music, San Antonio, TX, April 2014.

Malcolm, Noel. "Private and Public Knowledge: Kircher, Esotericism, and the Republic of Letters." In Athanasius Kircher: The Last Man Who Knew Everything, edited by Paula Findlen, 297-308. New York: Routledge, 2004.

McClure, George W. The Culture of Profession in Late Renaissance Italy. Toronto: University of Toronto Press, 2004.

McKay, John Zachary. "Universal Music-Making: Athanasius Kircher and Musical Thought in the Seveteenth Century." PhD diss., Harvard University, 2012.

McKinnon, James W. "Jubal vel Pythagoras, quis sit inventor musicae?" Musical Quarterly 64 (1978): 1-28.

Miller, Peter N. Peiresc's Europe: Learning and Virtue in the Seventeenth Century. New Haven: Yale University Press, 2000.

Mischiati, Oscar. Indici, cataloghi e avvisi degli editori e librai musicali italiani dal 1591 al 1798. Florence: Leo S. Olschki, 1984.

Palisca, Claude V. “The Genesis of Mattheson's Style Classification.” In New Mattheson Studies, edited by George J. Buelow and Hans Joachim Marx, 409-23. Cambridge: Cambridge University Press, 1983.

Palisca, Claude V., and Zygmunt M. Szweykowski. "Scacchi, Marco." Grove Music Online. Oxford Music Online. Oxford University Press. Accessed August 4, 2015. http://www.oxfordmusiconline.com/subscriber/article/grove/music $/ 44005$.

Patalas, Aleksandra. "Contributions to the Biography of Marco Scacchi on the Basis of the Composer's Testaments and Those of His Wife." In Musica baltica: The Music Culture of Baltic Cities in Modern Times, edited by Janusz Krassowski and 
Jolanta Woźniak, 249-66. Gdańsk: Akademia Muzyczna im. Stanisława Moniuszki w Gdańsku, 2010.

_. "Music Theory of Giovanni Maria Artusi in the Polemic Writings and in the Music of Marco Scacchi." Musica Iagellonica 4 (2007): 19-47.

—. "Ut oratio sit Domina: The Dispute between Romano Micheli and Marco Scacchi." In The Dissemination of Music in Seventeenth-Century Europe: Celebrating the Düben Collection, edited by Erik Kjellberg, 219-38. Varia musicologica 18. Bern: Peter Lang, 2010.

. W kościele, w komnacie $i w$ teatrze Marco Scacchi: Życie, muzyka, teoria. Kraków: Musica Iagellonica, 2010.

Quondam, Amedeo. "L'Accademia." In Letteratura italiana: Il letterato e le istituzioni, edited by Alberto Asor Rosa, 1:823-98. Turin: Giulio Einaudi, 1982.

Raz, Carmel Addie. "Reverberating Nerves: Physiology, Perception, and Early Romantic Auditory Cultures." PhD diss., Yale University, 2015.

Rosand, Ellen. Opera in Seventeenth-Century Venice: The Creation of a Genre. Berkeley: University of California Press, 1991.

Sabaino, Daniele. "Musica universalis, universus musicalis: forme e contenuti della musica culmine e chiave universale delle scienze nel riscoperto finale del trattato enciclopedico Musica di Juan Caramuel Lobkowitz." In Musicam in subtilitate scrutando: Contributi alla storia della teoria musicale, edited by Maria Teresa Rosa-Barezzani, Daniele Sabaino, and Rodobaldo Tibaldi, 311-70. Lucca: Libreria Musicale Italiana, 1994.

Simi Bonini, Eleonora. "Angelo Berardi: a distanza di poco più di tre secoli dalla scomparsa, una catalogazione completa delle opere rende finalmente onore al musicista marchigiano." Nuova rivista musicale italiana 35 (2001): 497-534.

- Catalogo del fondo musicale di Santa Maria in Trastevere nell'archivio storico del Vicariato di Roma: Tre secoli di musica nella basilica romana di Santa Maria in Trastevere. Rome: Ibimus, 2000.

Stolzenberg, Daniel. Egyptian Oedipus: Athanasius Kircher and the Secrets of Antiquity. Chicago: University of Chicago Press, 2013.

Timms, Colin. Polymath of the Baroque: Agostino Steffani and His Music. Oxford: Oxford University Press, 2003.

Tomlinson, Gary. Monteverdi and the End of the Renaissance. Berkeley: University of California Press, 1987.

- Music in Renaissance Magic: Toward a Historiography of Others. Chicago: University of Chicago Press, 1993.

Vickers, Brian. "Leisure and Idleness in the Renaissance: The Ambivalence of otium." Renaissance Studies 4 (1990): 1-37, 107-54.

Whitney, Elspeth. "Paradise Restored: The Mechanical Arts from Antiquity through the Thirteenth Century." Transactions of the American Philosophical Society 80, no. 1 (1990): 1-169.

Wilding, Nick. “'If You Have a Secret, Either Keep It, or Reveal It': Cryptography and Universal Language." In The Great Art of Knowing: The Baroque Encyclopedia of Athanasius Kircher, edited by Daniel Stolzenberg, 93-103. Stanford: Stanford University Libraries, 2001.

Witzenmann, Wolfgang. "Introduction." Translated by Hugh Ward-Perkins. In Giovanni Andrea Angelini-Bontempi: Nova quatuor vocibus componendi methodus, xix-xxviii. Lucca: Libreria Musicale Italiana, 1993. 


\section{Abstract}

This paper treats plagiarism as performance and Angelo Berardi as a virtuoso. Berardi (1636-94), an active composer and musician, is remembered for his half dozen musical writings. Beginning with a discussion of previously lost or unknown writings by Berardi and his mentor Marco Scacchi, I demonstrate that Berardi composed his prose works through a highly self-conscious process of borrowing. More broadly, Berardi's case opens a window onto the construction of musical texts and simultaneously complicates them as straightforward sources of musical information. Musicians used-and appropriated - the written word to craft and project personae in response to epistemological and social disadvantages: theory outranked practice and theorists outranked practitioners. In style, technique, and content Berardi is representative of musician-authors who presented themselves as gentlemen rather than musicians, adopted the style and tone of Italian academies and erudites, and favored more speculative matters (musical science, antiquarianism, friendship, combinatorics), sometimes at the expense of practical ones. They pursued metaphysical and quadrivial questions now disregarded as irrelevant. I argue that, on the contrary, such writings reveal most precisely, at their most "irrelevant" and derivative, a musical and even mental world not quite congruent with current interest in its musical artifacts.

Keywords: quadrivium, liberal arts, music theory, Angelo Berardi, Marco Scacchi, Zarlino 